\title{
The genus Charcotia Chevreux, 1906 in the Southern Ocean, with the description of a new species (Crustacea, Amphipoda, Lysianassoidea)
}

\author{
Cédric d'Udekem d'Acoz ${ }^{1, *}$, Isa Schön ${ }^{2}$ \& Henri Robert ${ }^{3}$ \\ 1,2,3 Royal Belgian Institute of Natural Sciences, Directorate Natural Environment, \\ rue Vautier 29, B-1000 Brussels, Belgium. \\ ${ }^{2}$ University of Hasselt, Research Group Zoology, Agoralaan Building D, B-3590 Diepenbeek, Belgium. \\ *Corresponding author: cdudekem@naturalsciences.be \\ ${ }^{1}$ urn:1sid:zoobank.org:author:8837E5E0-20FA-42E1-A9C9-19F130B68142 \\ ${ }^{2}$ urn:lsid:zoobank.org:author:94232F10-7092-4E90-9071-64C4FDABE691 \\ ${ }^{3}$ urn:1sid:zoobank.org:author:DAD6D058-79EC-40D6-B9A6-84A5222685BD
}

\begin{abstract}
It is demonstrated here that Charcotia Chevreux, 1906 (Amphipoda) has priority over Charcotia Vayssière, 1906 (Gastropoda), and that Waldeckia Chevreux, 1906 has to be treated as an invalid objective junior synonym of Charcotia Chevreux, 1906. An analysis of a part of the mitochondrial COI gene of Charcotia indicates that Charcotia obesa sensu lato, consists of two genetically distant clades that fulfil the criteria of genetic species. Each genetic clade corresponds to a different morphotype. The first one has a low triangular protrusion on the dorsal border of urosomite 1, a strong tooth on epimeron 3, and the posterodistal corner of the basis of pereiopod 7 is regularly rounded. It agrees with the original description of Charcotia obesa Chevreux, 1906. The second one has a protrusion of urosomite 1 prolongated by a sharp and usually long denticle, a small tooth on epimeron 3 , and the posterodistal corner of the basis of pereiopod 7 is bluntly angular. The second form is treated herein as a new species, Charcotia amundseni sp. nov., which is described in detail. While the bathymetric distribution of the two Antarctic Charcotia species overlaps (0-300 m for C. obesa and 7-1200 m for C. amundseni $\mathrm{sp}$. nov.), C. obesa largely predominates at depths of less than $150 \mathrm{~m}$, while Charcotia amundseni sp. nov. predominates at greater depths. Both species are widely distributed and presumably circum-Antarctic.
\end{abstract}

KEYWORDS. Waldeckia, Lysianassidae, Antarctica, taxonomy, DNA barcoding, new species.

d'Udekem d'Acoz C., Schön I. \& Robert H. (2018). The genus Charcotia Chevreux, 1906 in the Southern Ocean, with the description of a new species (Crustacea, Amphipoda, Lysianassoidea). Belgian Journal of Zoology 148 (1): 31-82. https://doi.org/10.26496/bjz.2018.18

\section{Introduction}

Charcotia obesa Chevreux, 1906 sensu lato (s.l.), which is better known as Waldeckia obesa (Chevreux, 1906), is a very common circum-Antarctic benthic lysianassoid amphipod of the Southern Ocean (DE 
BROYER et al., 2007). The suffix 'sensu lato' or 's.l.' is used when Antarctic Charcotia are treated collectively, as they are not taxonomically homogeneous (see below). C. obesa s.l. is a scavenger endowed with an enlarged stomach for storing large amounts of food during rare opportunities of feasting (Coleman, 1991, 1992a; DAuby et al., 2001b). Such episodes of gluttony are followed by several weeks of digestion (STORCH et al., 1999) and C. obesa s.l. is able to endure long (up to 18 months) periods of starvation (COLEMAN, 1991). Its scavenging way of life makes C. obesa s.l. easy to collect locally by the thousands with baited traps (STORCH et al., 1999). As it is easy to obtain large numbers of samples of this sturdy amphipod, it has been used as a model for a number of biological studies (DE BROYER et al., 2007). The role of $C$. obesa s.l. in the trophic web is not limited to its scavenging role, as it is also a part of the diet of fishes (LINKOWSKI et al., 1983) and seabirds (OFFREDO \& RIDOUX, 1986; JAŻDŻEWSKI \& KONOPACKA, 1999). Hence, BLUHM et al. (2001a) consider that Antarctic scavenging amphipods such as C. obesa s.l. represent an important link in the energy transfer to higher trophic levels and as energy recyclers of carrion.

According to DE BROYER et al. (2007), different species have been described or recorded from the Southern Ocean as belonging to the genus Waldeckia (i.e., Charcotia): Waldeckia zschaui (Pfeffer, 1888), Waldeckia obesa (Chevreux, 1906) (CHEVREux 1906a, b), Waldeckia chevreuxi Stebbing, 1910 (Bellan-SANTINI \& Ledoyer, 1974), Waldeckia arnaudi (Bellan-Santini, 1972) (BELlan-SANTINI, 1972, as Orchomene arnaudi), and Waldeckia robusta Ren in Ren \& Huang (1991) (REN \& HuANG, 1991). Records of Waldeckia zschaui (Pfeffer, 1888) result from confusions of C. obesa s.l. with Anonyx zschaui Pfeffer, 1888 (currently Orchomenella (Orchomenopsis) zschaui (Pfeffer, 1888)) (CHILton, 1912, 1913) and from the erroneous inclusion of Anonyx zschaui within the genus Waldeckia (SHOEMAKER, 1914). According to LOWRY \& KILGALLEN (2014), the record of W. chevreuxi (from Kerguelen Island) is based on an erroneous identification (not even belonging to the genus Waldeckia), while W. arnaudi and $W$. robusta were described after juvenile specimens of $W$. obesa. Until now, Charcotia obesa was thus the only validly described Antarctic Charcotia species. There were, however, reasons to question the taxonomic homogeneity of C. obesa. THURSTON (1974) described and illustrated two variants in the shape of the urosomite 1 in C. obesa and, in a phylogenetic study of Antarctic lysianassoids based on COI DNA sequence data, HAVERMANS (2014) indicated the existence of two clades within C. obesa, which were separated by genetic distances of the range to be expected between distinct lysianassoid species. The aim of the present study is to investigate in more depth the questions concerning the taxonomy of C. obesa s.l. raised by these two papers, by combining a molecular and a morphological approach.

Finally, Charcotia Vayssière, 1906 (Gastropoda) is suppressed in favour of Charcotia Chevreux, 1906 (Amphipoda).

\section{Material and methods}

\section{Sampling, stations and material}

Data of the sampling stations from the CEAMARC and REVOLTA expeditions were provided by Cyril Gallut (University Pierre et Marie Curie, Paris) and Laure Corbari (Muséum national d'Histoire naturelle, Paris) or obtained from the online database of the Muséum national d'Histoire naturelle, Paris. Twenty specimens from these two expeditions were selected for the DNA study, as they were suitable for molecular work, morphologically diverse and from a wide depth range. Stations of the RV Polarstern cruises were extracted from the RV Polarstern cruise reports: PS14 - ANT-VII/4 - EPOS leg. 3 from ARNTZ et al. (1990); PS39 - ANT-XIII/3 - EASIZ I from ARNTZ \& GUTT (1997); PS48 - ANTXV/3 - EASIZ II from ARNTZ \& GUTT (1999); PS69 - ANT-XXIII/8 from GUTT (2008); PS71 - ANTXXIV/2 - ANDEEP-SYSTCO from BATHMANN (2010); PS81 - ANT-XXIX/3 - LASSO from GUTT (2013). The approximate positions of the stations of the ARCTOWSKI expeditions were extracted from the MISTA internal database of RBINS. The positions of the stations of the Expéditions antarctiques Belgo-Néerlandaises were extracted from an unpublished data compilation created by Claude De Broyer 
(RBINS), except for station 211, which was extracted from GOSSE (1961). The stations of the RSS James Clark Ross were communicated by Huw Griffiths and Katrin Linse (BAS). Material collected prior to 2006 was fixed in formalin and subsequently transferred into ethanol. Material from the cruises PS69 - ANT-XXIII/8 (2006-2007) and PS71 - ANT-XXIV/2 includes both formalin- and alcohol-fixed specimens; details are given in the lists of material. Other material collected after 2007 was alcoholfixed.

\section{Molecular systematics}

DNA was extracted from the first pair of pleopods of the 20 selected specimens from the CEAMARC and REVOLTA expeditions. DNA extractions were conducted with the Machery-Nagel NucleoSpin Tissue DNA extraction kit and DNA concentrations measured with a Nanodrop. The Folmer region of the Cytochrome c Oxidase subunit I (COI) gene was amplified by PCR using the universal primer pair LCO1490/HCO2198 (FOLMER et al., 1994). PCRs were carried out in a T personal Thermoblock (Biometra) using $25 \mu \mathrm{l}$ volumes with the Qiagen HotStar Mastermix $(1.5 \mathrm{mM} \mathrm{MgCl}, 200 \mu \mathrm{M}$ dNTP, Tris $\cdot \mathrm{Cl}, \mathrm{KCl},\left(\mathrm{NH}_{4}\right)_{2} \mathrm{SO}_{4}, 1.25 \mathrm{U}$ Taq (a modified form of Taq DNA Polymerase) and $0.1 \mu \mathrm{M}$ of each primer. The cycling conditions were: $15 \mathrm{~min}$ at $95^{\circ} \mathrm{C}$, followed by 39 cycles of $50 \mathrm{sec}$ at $94^{\circ} \mathrm{C}, 50 \mathrm{sec}$ at $42^{\circ} \mathrm{C}$ and $1 \mathrm{~min}$ at $72^{\circ} \mathrm{C}$, followed by a final extension step of $72^{\circ} \mathrm{C}$ for 10 minutes. Amplification success was verified by agarose gel electrophoresis and staining of gels with Midori Green. PCR products were purified enzymatically with Exo-SAP IT ${ }^{\mathrm{TM}}$ (Affymtrix ${ }^{\mathrm{TM}}$ ) and sequenced directly in both directions with the PCR primers and the Big Dye kit (ABI) following the manufacturer's protocol on an ABI 3130x1 capillary DNA sequencer (Life Technologies).

Sequencing chromatograms were visualized and assembled with CodonCode Aligner v2.0.6 to generate consensus sequences. Sequence identity was confirmed by BLAST searches (ALTSCHUL et al., 1997). All sequences were aligned using ClustalX (LARKIN et al., 2007), ambiguities corrected manually and all sequences trimmed to equal lengths in BioEdit 7.2.5 (HALL, 1999). All sequences have been submitted to GenBank (see below). The final alignment including Parawaldeckia kidderi (Smith, 1876) from GenBank (accession number FJ608977) as outgroup was used to select the best-fitting model of molecular evolution with jModeltest 2.1.7 (DARRIBA et al., 2012) searching among 88 different nucleotide substitution models and using the corrected Akaike Information Criterion (AICc).

The parameters of the best-fitting evolutionary model were used in phylogenetic reconstructions with Maximum Likelihood (ML) and Bayesian approaches. PHYML 3.0 (GUINDON \& GASCUEL, 2003) was used to construct ML trees with 1000 bootstraps. For COI, the $\mathrm{TrN}+\mathrm{I}$ model and the following parameters were used: freqA $=0.2732$; freqC $=0.2039$; freq $=0.1732$; freq $=0.3498 ;[\mathrm{AC}]=1.0000$; $[\mathrm{AG}]=4.1174 ;[\mathrm{AT}]=1.0000 ;[\mathrm{CG}]=1.0000 ;[\mathrm{CT}]=8.1936 ;[\mathrm{GT}]=1.0000 ; \mathrm{p}$-inv $=0.6080$.

Phylogenetic trees were also constructed with Bayesian approaches in MrBayes 3.2 (RONQUIST et al., 2012) with the HKY85+I model (because this model had the highest likelihood in jModeltest from the models being available in MrBayes), running MCMC chains for 2,000,000 generations with default prior and MCMC settings, sampling trees every 1000 generations. After inspecting split frequencies and Potential Scale Reduction Factors to ensure convergence, the first 10,000 trees were eliminated as burn-in, and the 50\% majority rule consensus tree was calculated and visualized with FigTree v. 1.4.3 (http:/ tree. bio.ed.ac.uk/software/figtree). We also constructed parsimonious tcs networks (CLEMENT et al., 2000) in popart 1.2 (http://popart.otago.ac.nz) to visualize genetic relationships between specimens at a finer scale. To test statistically if DNA sequences fall into discrete categories resembling genetic species, the Poisson Tree Process algorithm of ZHANG et al. (2013a) was applied. In short, this method models substitution patterns in phylogenetic trees from the number of substitutions, distinguishing within and between species. The COI ML phylogeny (without outgroup and bootstraps) was loaded on the website of bPTP (http://sco.h-its.org/exelixis/web/software/PTP) and the PTP models were calculated with the default options of 100,000 MCMC generations and a burn-in of $10 \%$, and convergence checked. 
We also applied the Automatic Barcode Gap Discovery method (ABGD; PUILLANDRE et al., 2012) on the ABGD website (http://wwwabi.snv.jussieu.fr/public/abgd/), which uses the barcode gap between intra- and interspecific genetic distances to partition the sequence data into different groups representing candidate genetic species. We applied both models currently available for ABGD online to calculate genetic distances, JC69 and K80. Also, genetic distances within and between the two phylogenetic clades were calculated in MEGA 6.0 (TAMURA et al., 2013), using the TAMURA-NEI model and 1,000 bootstrap replicates for variance estimates.

\section{Map}

The map was created using Quantarctica (MATSUOKA et al., 2013).

\section{Morphological systematics}

Relevant specimens and appendages were examined in alcohol with a Wild 181300 dissecting microscope equipped with a drawing tube. Pencil drawings were scanned and inked with the software ADOBE ILLUSTRATOR 11.0.0 on an A3 drawing table (Wacom Intuos3 12x19), using the method described by COLEMAN $(2003,2009)$. Some specimens and appendages were then air-dried, mounted on SEM stubs, gold coated and examined under a FEI QUANTA 200 scanning electron microscope. SEM photographs were taken by Julien Cillis (RBINS). Descriptive accounts are based on these drawings and photographs.

The following abbreviations are used in the captions of figures:

$\begin{array}{ll}\text { A1 } & =\text { antenna 1 } \\ \text { A2 } & =\text { antenna 2 } \\ \text { Ep1-Ep3 } & =\text { epimeral plates 1-3 } \\ \text { Gn1 } & =\text { gnathopod 1 } \\ \mathrm{Gn} 2 & =\text { gnathopod } 2 \\ \mathrm{Md} & =\text { mandible } \\ \mathrm{Mx} 1 & =\text { maxilla 1 } \\ \mathrm{Mx} 2 & =\text { maxilla 2 } \\ \mathrm{Mxp} & =\text { maxilliped } \\ \mathrm{P} 3-\mathrm{P} 7 & =\text { pereiopods } 3-7 \\ \mathrm{U} 1-\mathrm{U} 3 & =\text { uropods } 1-3\end{array}$

In the descriptions, the term "tooth" is used for non-articulated, pointed ectodermic structures, 'spine' for stout, inflexible, articulated structures, and the term 'seta' for slender, flexible, articulated structures. For a discussion on the pertinence of this terminology, see D'UDEKEM D'ACOZ (2010). Nomenclature of the setae of the mandibular palp follows LOWRY \& STODDART (1993).

\section{Results}

\section{Approach}

To some extent, the present study follows a reverse taxonomy approach (e.g., KANZAKI et al., 2012, D'UDEKEM D'ACOZ \& HAVERMANS, 2015). In a first step, twenty specimens of ethanol-fixed Charcotia obesa s.l. from the REVOLTA and CEAMARC campaigns were selected on the basis of a rapid examination of their morphology and of their collecting depth. More specifically, these specimens showed a wide range of variation in the shape of urosomite 1, with the two forms of THURSTON (1974) as extremes, and were collected from a wide range of depths (140-1,200 m). COI sequences of the successfully sequenced specimens were analysed to delimit genetic species. The molecular data confirmed the existence of two widely separated clades (see below). Then, a second and closer examination of the successfully sequenced test specimens was carried out in order to check the existence of morphological differences between clades and of individual variation within clades. This confirmed 
the existence of two morphospecies, corresponding more or less to the two forms of THURSTON (1974) and presenting other - more constant - differences. Other samples (mostly old ones fixed in formalin) from distant Antarctic areas and different depths were then also examined, to establish the range of morphological variation of the two species, and their geographical and bathymetric distribution. Finally, the morphology of these two species was illustrated in detail.

\section{Remark}

When the manuscript of this paper was ready for submission, SEEFELDT et al. (2017) published observations on 'Waldeckia obesa' similar to ours, but with less detail and without formally describing the new species. The two studies were carried out independently.

\section{DNA analysis}

Partial COI sequences were successfully obtained for 12 individuals and their identity confirmed with BLAST. The phylogenetic tree shows two separate clusters of COI sequences with both ML and Bayesian methods (Fig. 1A) and high statistical support. Each cluster consists of sequences from a different morphospecies, C. obesa sensu stricto (s.s.) and C. amundseni sp. nov., respectively. The same two groups are obvious from the structure of the parsimonious network (Fig. 1B). Applying the PTP algorithm reveals that both clades fulfil the statistical criteria to be regarded as different genetic species (Fig. 1). The ABGD method partitions the dataset into two genetic groups regardless of which model was used to calculate genetic distances (data are available on request). In addition, genetic distances among clades $(0.99 \% \pm 0.37 \%$ for $C$. amundseni sp. nov. and $0.69 \% \pm 0.22 \%$ for $C$. obesa $)$ are much smaller than the genetic distance between the clades $(16.7 \% \pm 1.9 \%)$. Morphological examination demonstrates without any ambiguity that the two clades are also separated by several constant morphological characters. On

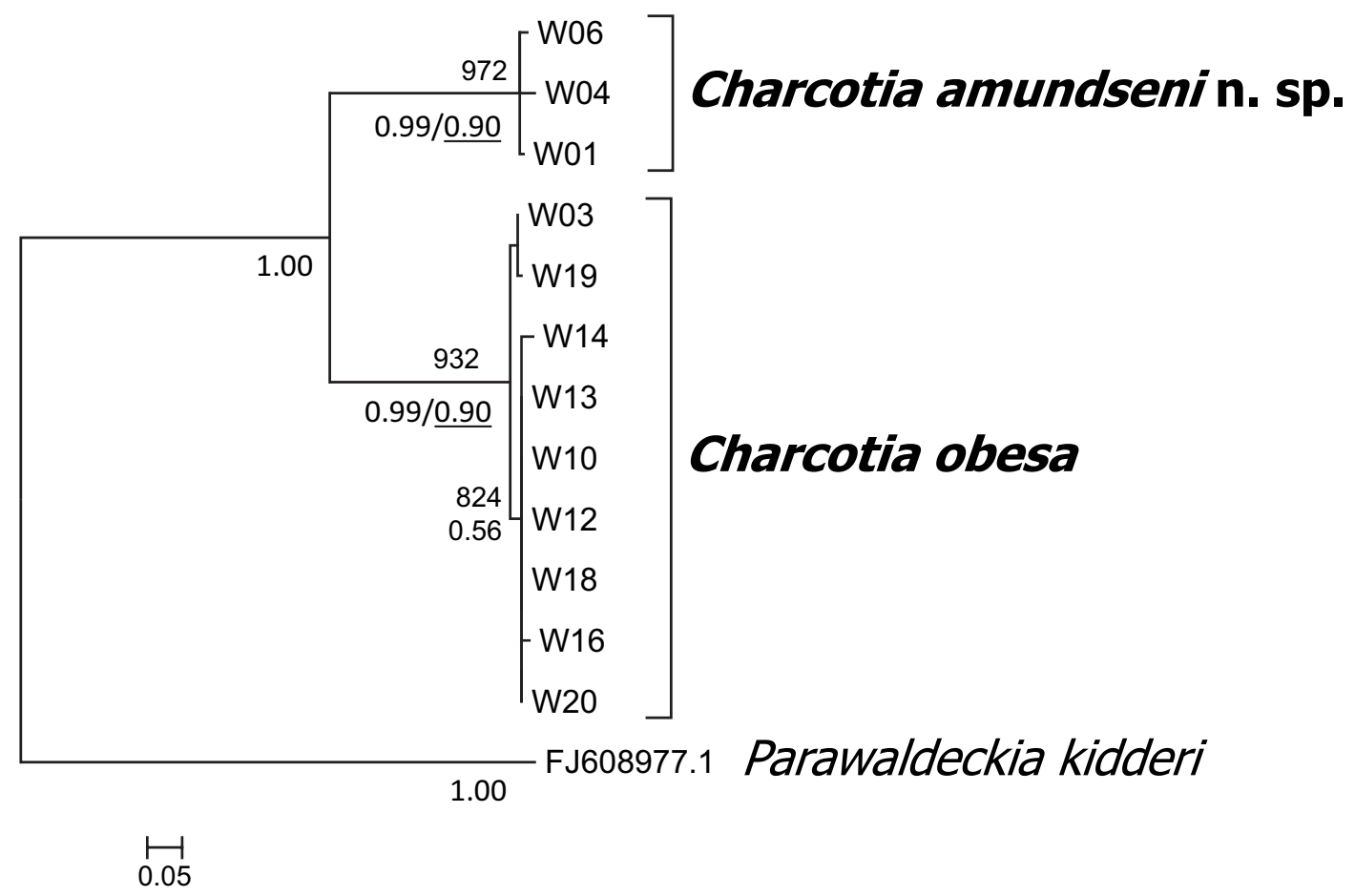

Fig. 1 - A. COI maximum likelihood tree, constructed from sequence data of 480 basepairs with ML and Bayesian approaches. Numbers above branches are bootstrap supports of 1000 replicates in PHYML, numbers below branches are posterior probabilities of MrBayes. The underlined numbers below branches are the probabilities of the PTP algorithm that this phylogenetic clade represents a genetic species. The morphological identity of each phylogenetic clade is indicated at the right. For further information on the specimens, refer to the species descriptions. 
the basis of these congruent genetic and morphological data, it is concluded that two different Charcotia species are present in the investigated samples. The diagnostic characters observed on the sequenced specimens could be confirmed by the subsequent morphological examination of other specimens. The two species are morphologically characterized in the next section. As there was a perfect match between the COI species and the morphological units, and as the morphological units were separated by clearcut morphological differences, there is no need to sequence other genes for solving the taxonomy of Antarctic Charcotia.

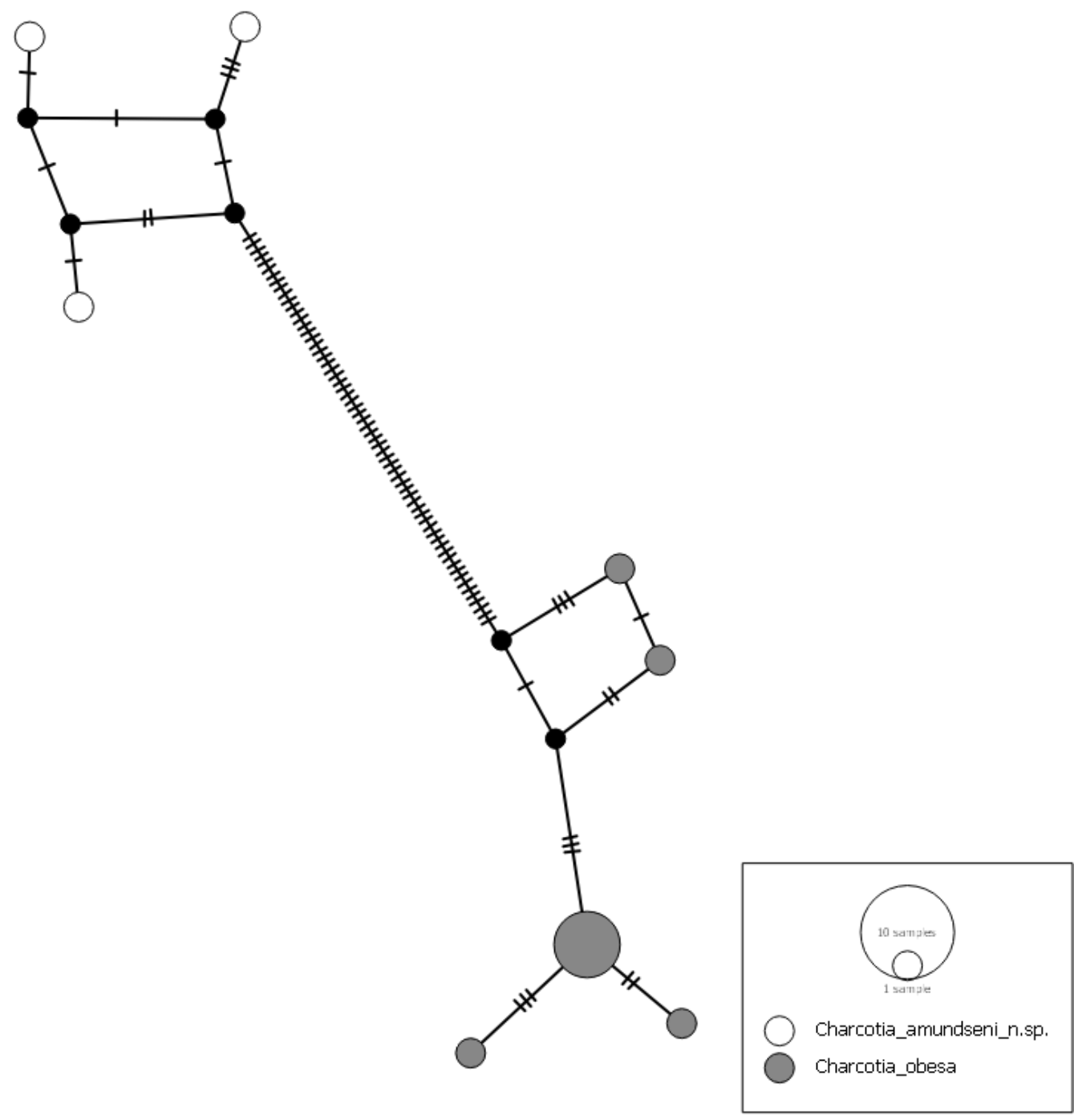

Fig. 1 - B. Parsimonious network based on COI sequence data. Circle size is proportional to the number of individuals with the same sequence (or number of haplotypes). Small, black circles represent missing haplotypes. The different phylogenetic clades and morphospecies are indicated by different colours. 


\title{
Taxonomic account
}

\author{
Subphylum Crustacea Brünnich, 1772 \\ Order Amphipoda Latreille, 1816 \\ Superfamily Lysianassoidea Dana, 1849 \\ Family Lysianassidae Chevreux, 1907 \\ Subfamily Waldeckiinae Lowry \& Kilgallen, 2014
}

Genus Charcotia Chevreux, 1906

Charcotia ChevreuX, 1906a [Jan. 1906]: 163. — WALKer, 1906 [1 May 1906 (see Evenhuis (2003)]: 451.

Waldeckia CHEVReuX, 1906b [presumably Dec. 1906, date indicated on back of volume]: 13.

non Charcotia VAYSSIÈRE, 1906a [after 19 Mar. 1906]: 719 [nomen nudum]. — VAYSSIÈRE, 1906b [between 27 Mar. 1906 and 1 May 2016]: 148. — VAYSSIÈRE, 1906c [presumably Dec. 1906, date indicated on back of volume]: 27 (Mollusca).

\section{Taxonomy and nomenclature}

Chevreux (1906a) created the genus Charcotia Chevreux, 1906 for a new lysianassoid amphipod, described by him as Charcotia obesa Chevreux, 1906. That paper is usually cited as published in 1905. However, the "Bulletin de la Société Zoologique de France" for 1905, in which the paper was published, included a report of a session of December $26^{\text {th }}, 1905$, i.e., at the very end of 1905 . At our request, Martyn E.Y. Low (National University of Singapore) investigated the issue and concluded that the Bulletin was published in January 1906: "I think Charcotia Chevreux can be dated to January 1906 and predates Charcotia Vayssière (after 19 March 1906)" (pers. comm. of 10 May 2017). He justified his conclusion, in referring to WALKER (1906: 451), who wrote that the paper of CHEVREUX was published in January 1906. CHEVReuX (1906b) introduced the replacement name Waldeckia Chevreux, 1906 for Charcotia Chevreux, 1906, in giving the following explanation: "Le nom de Charcotia étant déjà employé pour désigner un genre de mollusques nudibranches, je prie M. le Dr Jean Charcot de vouloir bien m'autoriser à le remplacer par le nom de sa sœur, Mme Waldeck-Rousseau" [The name Charcotia being already in use for a genus of nudibranch molluscs, I ask to Dr. Jean Charcot to allow me to replace it by the name of his sister, Mrs Waldeck-Rousseau]. The statements of CHEVREUX (1906b) were accepted in all subsequent literature. However, as stated above, they are inexact, as Charcotia Chevreux, 1906 (Crustacea, Amphipoda) was published earlier than Charcotia Vayssière, 1906 (Mollusca, Gastropoda, Nudibranchia). The principle of priority (ICZN 1999, Art. 23) should then be applied. A reversal of precedence is not possible because Art. 23.9.1.1 of ICZN (1999) is not respected (the senior homonym was published after 1899). Charcotia Chevreux, 1906 is therefore re-established in application of the principle of priority and Charcotia Vayssière, 1906 becomes a junior homonym of it. The replacement name Curnon d'Udekem d'Acoz in Bouchet et al., 2017 was introduced for the gastropod genus in BOUCHET et al. (2017). The year of publication of the name Waldeckia is uncertain, but it is treated herein as if it was published in late 1906, as in former literature. The date "December 1906" is indicated on the back of the volume of "Crustacés amphipodes" of the "Expédition Antarctique Française (1903-1905)", but the Nomenclator Zoologicus (http://ubio.org/browser/details.php?namebankID=4391914 and http:// ubio.org/NZ/PDF/Vo14/pg0650.png, accessed 11 May 2017) states that it was published in 1907 without explanation. The validity of the subfamily Waldeckiinae Lowry \& Kilgallen, 2014 is unaffected by the replacement of Waldeckia Chevreux, 1906 by Charcotia Chevreux, 1906 (ICZN, 1999, Art. 40.1.).

The genus Waldeckia was reviewed by LOWRY \& KILGALLEN (2014) and one more species was described by LOWRY \& KilgaLlen (2015). As a consequence of the re-establishment of Charcotia Chevreux, 1906 and of the description of C. amundseni sp. nov., the checklist of LOWRY \& KILGALLEN (2015) should be modified and updated as follows: 
Charcotia amundseni sp. nov.

Charcotia australiensis (Haswell, 1879)

Charcotia bamberi (Lowry \& Kilgallen, 2015)

Charcotia brachycephala (Ren, 1998)

Charcotia crenulata (Pirlot, 1936)

Charcotia dempseyae (Lowry \& Kilgallen, 2014)

Charcotia enoei (Stephensen, 1931)

Charcotia kroyeri (White, 1847)

Charcotia nitens (Haswell, 1879)

Charcotia nudum (Imbach, 1967)

Charcotia obesa Chevreux, 1906

Charcotia orchospina (Hirayama, 1986)

Charcotia selayarensis (Lowry \& Kilgallen, 2014)

Charcotia tangaroa (Lowry \& Kilgallen, 2014)

Charcotia tomiokaensis (Hirayama, 1986)

Charcotia warreen (Lowry \& Kilgallen, 2014)
Antarctica

Australia

Austral Isles, Society Islands

South China Sea

Sulu Archipelago; Philippines

Australia

Australia; Indonesia

Australia

Australia

Vietnam, South China Sea

Antarctica

Japan

Australia; Indonesia

Australia, Tasman Sea

Japan

Australia

\section{Key to Charcotia species with a dorsal dentiform process on urosomite 1}

1. Epimeron 3 posteroventrally produced into a tooth [Antarctica] .2

- Epimeron 3 posteroventrally not produced into a tooth [SE Australia]

Charcotia tangaroa (Lowry \& Kilgallen, 2014)

2. Urosomal process obtusely triangular (Fig. 20B); epimeron 3 with medium-sized posteroventral tooth (Fig. 20A); basis of pereiopod 7 with posterodistal corner regularly rounded (Fig. 19G)

Charcotia obesa Chevreux, 1906

- Urosomal process almost always terminated by a narrow tooth pointing upwards (Fig. 12C); epimeron 3 with very small posteroventral tooth (Fig. 12B); basis of pereiopod 7 with posterodistal corner subangular (Fig. 11G)

Charcotia amundseni sp. nov.

Charcotia amundseni sp. nov.

urn:lsid:zoobank.org:act:B72F0867-BD98-4B93-969F-66169BECC5E1

Figs 1-2, 3A, 4A, 5A, 6-14

Waldeckia obesa-SCHELLENBERG, 1926: 253, fig. 9. - THURSTON, 1974: 64, in part, fig. 25c (not 25ab). - NAGATA, 1986: 255, figs 7-8. - RAUSCHERT \& ARNTZ, 2015: 69, pl. 62, unnumbered photo. Waldeckia obesa cluster B - SEEFELDT et al. 2017: 9.

Waldeckia zschauii - CHILTON, 1912: 471, in part (Scotia stn 411 material only).

Waldeckia zschaui-CHILTON, 1913: 56, in part (Scotia material only).

non Anonyx zschauii Pfeffer, 1888: 87, pl. 2 fig. 1 (= Orchomenella (Orchomenopsis) zschauii (PFEFFER, 1888)).

non Charcotia obesa Chevreux, 1906a: 163, fig. 3.

\section{Type locality}

ANTARCTIC: Adélie Coast, $65.989378^{\circ} \mathrm{S}, 139.994898^{\circ} \mathrm{E}$ to $66.01644^{\circ} \mathrm{S}, 140.000462^{\circ} \mathrm{E}, 189-196 \mathrm{~m}$.

\section{Material examined}

Holotype

ANTARCTIC: +, Cruise CEAMARC, Adélie Coast, sample 3226, stn 20, event 490, 65.989378 S, $139.994898^{\circ} \mathrm{E}$ to $66.01644^{\circ} \mathrm{S}, 140.000462^{\circ} \mathrm{E}, 189-196 \mathrm{~m}$, beam trawl, 15 Jan. 2008 (MNHNIU-2016-8908, extraction H. Robert W06, GenBank nr MH078077). 


\section{Paratypes}

ANTARCTIC: 1 specimen (sex not recorded), Cruise CEAMARC, Adélie Coast, sample V3 3156, stn 17 , event $485,66.169132^{\circ} \mathrm{S}, 139.932052^{\circ} \mathrm{E}$ to $66.174595^{\circ} \mathrm{S}, 139.989905^{\circ} \mathrm{E}, 140-152 \mathrm{~m}$, beam trawl, 15 Jan. 2008 (MNHN-IU-2016-3823, extraction H. Robert W01, GenBank nr MH078076). — 1 specimen (sex not recorded), sample V3 3156, stn 17 (same coordinates) (MNHN-IU-2016-3824, extraction H. Robert W02, sequencing not successful). - 1 specimen (immature female) dissected and partly mounted on 15 SEM stubs and gold-coated (carcass preserved in alcohol), sample 3477, stn 84, event 520, $65.444595^{\circ} \mathrm{S}, 139.318593^{\circ} \mathrm{E}$ to $65.469418^{\circ} \mathrm{S}, 139.432493^{\circ} \mathrm{E}, 1137-1241 \mathrm{~m}$, beam trawl, $16 \mathrm{Jan} .2008$ (MNHN-IU-2016-6552, extraction H. Robert W04, GenBank nr MH078078). — 1 specimen (sex not recorded), sample 3226 , stn 20 , event $490,65.989378^{\circ} \mathrm{S}, 139.994898^{\circ} \mathrm{E}$ to $66.01644^{\circ} \mathrm{S}, 140.000462^{\circ} \mathrm{E}$, 189-196 m, beam trawl, 15 Jan. 2008 (MNHN-IU-2016-3825, extraction H. Robert W05, sequencing not yet successful). - 1 specimen (sex not recorded), sample 3226, stn 20, event 490 (same coordinates) (MNHN-IU-2016-3826, extraction H. Robert W07, sequencing not yet successful). - 1 specimen (sex not recorded), sample 3226, stn 20, event 490 (same coordinates) (MNHN-IU-2016-3827, extraction H. Robert W08, sequencing not yet successful). - 2 specimens, from the stomach of a Trematomus hansoni Boulenger, 1902, Expéditions antarctiques Belgo-Néerlandaises (EABN), Enderby Land, stn 211, King Léopold III Bay, $70^{\circ} 18^{\prime} \mathrm{S}, 24^{\circ} 13^{\prime} \mathrm{E}$, bottom consisting of dark gray mud with small stones, 250-258 m, temperature $-1.8^{\circ} \mathrm{C}$, baited trap, between 10 Jan. 1961 and 2 Feb. 1961 (RBINS INV. 132819). 1 specimen, from the stomach of a Trematomus hansoni Boulenger, 1902, stn 211 (same coordinates) (RBINS INV. 132821). - 1 specimen, station lost, presumably King Léopold III Bay, baited trap, between 10 Jan. 1961 and 2 Feb. 1961 (RBINS INV.132822). - 2 specimens, labelled "sta. E.A.B. D1 C2, nasse/fond, 19/I/61", presumably stn 153, King Léopold III Bay, no precise coordinates, 255 m, baited trap, 19 Jan. 1961 (RBINS INV. 132816). - 1 specimen, stn 213, King Léopold III Bay, coordinates missing, $250 \mathrm{~m}$ (?), 19 Jan. 1965, dredge (RBINS INV. 132820). - 8 specimens, stn 213 , King Léopold III Bay, no precise coordinates, $250 \mathrm{~m}$ (?), baited trap, 19 Jan. 1965 (RBINS INV. 132810). - 1 specimen, stn 214, King Léopold III Bay, no precise coordinates, $234 \mathrm{~m}$, baited trap, 24-25 Jan. 1965 (RBINS INV. 132813). - 1 specimen, stn 220, Baie U.S.S. Glacier, no precise coordinates, 414-450 m, 1 Feb. 1965 (RBINS INV. 132815). — 2 specimens, stn 222/223/224, Baie U.S.S. Glacier, no precise coordinates, 207 m, 3 Feb. 1965 (RBINS INV. 132814). — 23 specimens, stn 329, no precise Lat/long coordinates, King Léopold III Bay, 170 m, baited trap, 26 Jan. 1966 (RBINS INV. 132823). - 1 specimen, stn 232 , King Léopold III Bay, $70^{\circ} 17^{\prime} \mathrm{S}, 24^{\circ} 15^{\prime} \mathrm{E}$, gravel and stones, trawl, about 300 m, 25 Jan. 1967 (RBINS INV. 132812). - 1 specimen, stn 236, Enderby Land, King

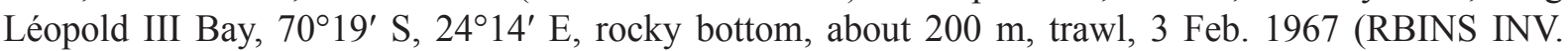
132818). - 1 specimen, stn 236 (same coordinates) (RBINS INV. 132811). - 1 specimen, $R V$ Polarstern, PS14, ANT-VII/4, EPOS leg. 3, East Weddell Sea, coll. C. De Broyer, stn 272 (AGT 16), $73^{\circ} 26.9^{\prime} \mathrm{S}, 2^{\circ} 33.6^{\prime} \mathrm{W}$ to $73^{\circ} 25.7^{\prime} \mathrm{S}, 2^{\circ} 30.2^{\prime} \mathrm{W}, 406-409 \mathrm{~m}$, Agassiz trawl, $13 \mathrm{Feb} .1989$ (RBINS INV. 132777). - 1 specimen, stn 275 (AGT 19), $71^{\circ} 39.5^{\prime} \mathrm{S}, 12^{\circ} 34.7^{\prime} \mathrm{W}$ to $71^{\circ} 39.0^{\prime} \mathrm{S}, 12^{\circ} 11.7^{\prime} \mathrm{W}, 301-$ $330 \mathrm{~m}$, Agassiz trawl, 15 Feb. 1989 (RBINS INV. 132776). — 1 specimen (used for gut content studies), stn 284 (GSN 13), $71^{\circ} 12.0^{\prime} \mathrm{S}, 13^{\circ} 14.0^{\prime} \mathrm{W}$ to $71^{\circ} 12.2^{\prime} \mathrm{S}, 13^{\circ} 16.8^{\prime} \mathrm{W}, 402-412 \mathrm{~m}$, bottom trawl, 18 Feb.

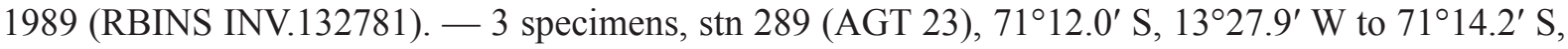
13³6.0' W, 672-677 m, Agassiz trawl, 19 Feb. 1989 (RBINS INV. 132778). — 1 specimen (used for gut content studies), stn 289 (AGT 23) (same coordinates) (RBINS INV. 132779). - 1 specimen (used for gut content studies), stn 289 (AGT 23) (same coordinates) (RBINS INV. 132780). — 1 specimen (used for gut content studies, specimen 17), stn 289 (AGT 23) (same coordinates) (RBINS INV. 132782). - 1 specimen (used for gut content studies, specimen 20), stn 289 (AGT 23) (same coordinates) (RBINS INV. 132783). - 1 specimen (used for gut content studies, specimen 15), stn 289 (AGT 23) (same cordinates) (RBINS INV. 132784). - 18 small specimens (including specimens 19 and 22 of gut content analyses, in separate plastic tubes), stn 289 (AGT 23) (same coordinates) (RBINS INV. 132785). 8 very large specimens, $R V$ Polarstern, PS39, ANT-XIII/3, EASIZ I, East Weddell Sea, coll. C. De Broyer, stn 39-12, T3, 73ำ $15.80^{\prime} \mathrm{S}, 2^{\circ} 04.60^{\prime} \mathrm{W}, 791 \mathrm{~m}$, baited trap, 13-16 Feb. 1996 (RBINS INV. 132765). - 2 very large specimens [specimens presumably brought back alive to Belgium], labelled as "aquarium 
24, PS NUT 32, 31 Jul. 1996" (RBINS INV. 132766). — 15 large specimens, no station, labelled as "PS NUT 22, 29/5" (RBINS INV. 132767). - 3 large specimens [presumably brought back alive to Belgium], no station, labelled as "aquarium de manipulation, 12 Jul. 1996" (RBINS INV. 132769). — 9 specimens,

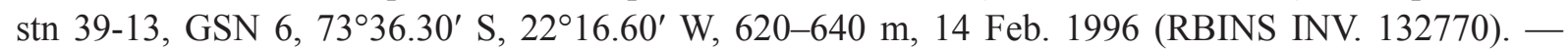
2 specimens, no station, "2T AQ 25, PS NUT 33" (RBINS INV. 132772). - 2 specimens, stn 39-6, T2, P2, 71 ${ }^{\circ} 31.40^{\prime} \mathrm{S}, 13^{\circ} 31.60^{\prime} \mathrm{W}, 236 \mathrm{~m}, 10$ Feb. 1996 (RBINS INV. 132773). — 2 specimens, stn 39-12,

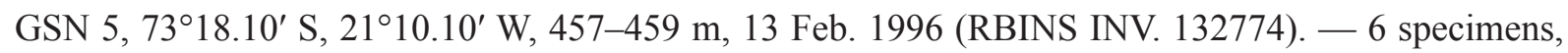
labelled as stn 6, P3 [presumably stn 39-6, T2, 71 ${ }^{\circ} 31.40^{\prime} \mathrm{S}, 13^{\circ} 31.60^{\prime} \mathrm{W}, 236 \mathrm{~m}, 10$ Feb. 1996] (RBINS INV.132775). - 10 specimens, RV Polarstern, PS48, ANT-XV/3, EASIZ II, East Weddell Sea, coll. C. De Broyer and Y. Scailteur, stn 152/153, 74 $36.8^{\prime} \mathrm{S}, 26^{\circ} 53.9^{\prime} \mathrm{W}$ and $74^{\circ} 36.3^{\prime} \mathrm{S}, 26^{\circ} 52.2^{\prime} \mathrm{W}, 585-597 \mathrm{~m}$, fish trap, 13 Feb. 1998 (RBINS INV. 132796). — 53 specimens, stn 150, 7440.0' S, $27^{\circ} 12.4^{\prime} \mathrm{W}$, GSN, 710-789 m, 10 Feb. 1998 (RBINS INV. 132797). — 45 specimens, stn 251/267, T10, 72॰47.8' S, $19^{\circ} 31.4^{\prime} \mathrm{W}$ to $72^{\circ} 48.3^{\prime} \mathrm{S}, 19^{\circ} 33.0^{\prime} \mathrm{W}$, baited trap, subsample, $857-895 \mathrm{~m}, 23$ to 25 Feb. 1998 (RBINS INV. 132798). - 143 specimens (all sizes), trap T9, $70^{\circ} 57.0^{\prime} \mathrm{S}, 11^{\circ} 40.6^{\prime} \mathrm{W}$ to $70^{\circ} 58.9^{\prime} \mathrm{S}, 11^{\circ} 39.8^{\prime} \mathrm{W}$, baited trap, 442-830 m, 18 to 20 Feb. 1998 [two traps, immersed at different positions and different depths were recovered on $20 \mathrm{Feb}$. 1998; from the label, the origin of the specimens cannot be established; hence imprecise Lat/Long and depth coordinates combining both stations are given] (RBINS INV. 132799). - 1 immature female specimen, air dried, gold coated and mounted on a SEM stub, trap T9 (same cordinates) (RBINS INV. 132836). - 107 specimens, initial fixation formalin, trap T9 (same cordinates) (RBINS INV. 132800). - 1 mature male (partly mounted on a SEM stub and gold-coated; carcass in alcohol), trap T9 (same cordinates) (RBINS INV. 132837). - 3 specimens, initial fixation alcohol 70', RV Polarstern, PS69, ANT-XXIII/8, coll. C. d'Udekem d'Acoz and H. Robert, East Weddell Sea, Atka Bay, stn $603-5,70^{\circ} 30.99^{\prime} \mathrm{S}, 08^{\circ} 48.08^{\prime} \mathrm{W}$ to $70^{\circ} 30.40^{\prime} \mathrm{S}, 08^{\circ} 48.13^{\prime} \mathrm{W}$, sponge bottom, 274 $297 \mathrm{~m}$, bottom trawl, 7 Dec. 2006 (RBINS INV. 122227). - 2 specimens, initial fixation alcohol $70^{\circ}$, specimens photographed on board, Elephant Island, stn $654-6,61^{\circ} 22.80^{\prime} \mathrm{S}, 56^{\circ} 03.84^{\prime} \mathrm{W}$ to $61^{\circ} 23.35^{\prime} \mathrm{S}$, 560․ $89^{\prime}$ W, 341-342 m, Agassiz trawl, 29 Dec. 2006 (RBINS INV. 122228). - 1 specimen, initial fixation formalin, RV Polarstern, PS71, ANT-XXIV/2, ANDEEP-SYSTCO, East Weddell Sea, coll. H. Robert, stn $48-1,70^{\circ} 23.94^{\prime} \mathrm{S}, 8^{\circ} 19.14^{\prime} \mathrm{W}$ to $70^{\circ} 23.89^{\prime} \mathrm{S}, 8^{\circ} 18.67^{\prime} \mathrm{W}$, bryozoan bottom, 595-602 m, 12 Jan. 2008 (RBINS INV. 132458). - 1 small specimen, initial fixation alcohol, RRS James Clark Ross, cruise JR230, stn DB 09-0361, West of Antarctic Peninsula, west of Adelaide Island, $67^{\circ} \mathrm{S}, 70^{\circ} \mathrm{W}$, 529 m, Agassiz trawl, Dec. 2009 (coll. BAS, NHMUK 2017.113). - 4 specimens, initial fixation alcohol, Stn DB 09-0928, West of Antarctic Peninsula, south of Adelaide Island, $68^{\circ} \mathrm{S}, 70^{\circ} \mathrm{W}, 530 \mathrm{~m}$, Agassiz trawl, Dec. 2009 (NHMUK 2017.114-NHMUK 2017.117). — 4 specimens (1 large, 2 mediumsized and 1 juvenile, initial fixation alcohol), RRS James Clark Ross, cruise JR275, stn 89, South East Weddell Sea, $74.6716^{\circ} \mathrm{S}, 29.39886^{\circ} \mathrm{W}$ to $74.6706^{\circ} \mathrm{S}, 29.3883^{\circ} \mathrm{W}, 639-657 \mathrm{~m}$, EBS-E, 29 Feb. 2012 (NHMUK 2017.118-NHMUK 2017.121). - 1 paratype, initial fixation alcohol, stn 99, South East Weddell Sea, $74.6341^{\circ} \mathrm{S}, 29.00812^{\circ} \mathrm{W}$ to $74.6357^{\circ} \mathrm{S}, 28.9996^{\circ} \mathrm{W}, 959-986 \mathrm{~m}$, EBS-S, 1 Mar. 2012 (coll. BAS, NHMUK 2017.122). — 1 specimen, initial fixation alcohol, RRS James Clark Ross, cruise $J R 15005$, SO AntEco, stn 0938, event 45, South Orkney Islands, $62.33288^{\circ} \mathrm{S}, 44.52622^{\circ} \mathrm{W}$ to $62.32868^{\circ} \mathrm{S}, 44.53451^{\circ} \mathrm{W}, 1006-1055 \mathrm{~m}$, Agassiz trawl, 7 Mar. 2016 (coll. BAS, NHMUK 2017.123). 1 paratype, initial fixation alcohol, RRS James Clark Ross, cruise not specified, "B105, EBS, C3 EPI", Amundsen Sea, $73.98152^{\circ} \mathrm{S}, 107.39665^{\circ} \mathrm{W}$ to $73.98395^{\circ} \mathrm{S}, 107.39035^{\circ} \mathrm{W}, 540-547 \mathrm{~m}$, no date (NHMUK 2017.124).

\section{Etymology}

The specific epithet is dedicated to the memory of Roald Amundsen, conqueror of the South Pole and first mate on the RV Belgica during the historical Belgian Antarctic Expedition. The name is a Latin genitive. 


\section{Differential diagnosis}

Epistome/upper lip complex: epistome concave, upper lip rounded and protruding forward; connection between epistome and upper lip not forming a sinus. Pereiopod 5: coxa posteroventral corner very bluntly angular; basis with anterior border forming a blunt angle on its distal 0.6. Pereiopod 6: basis posterodistal border rounded but not extremely broad; anterior and posterior borders strongly convergent. Pereiopod 7: basis posterodistal border very weakly convex (nearly straight), not projecting into a low distal lobe, junction between posterodistal and posterior border forming a curve with a distinct angular discontinuity. Pleonite 3: posteroventral corner of epimeron with small tooth. Urosomite 1: posteriorly with a tooth pointing upwards, which is usually long and fairly narrow but which is sometimes (rarely) reduced to a small triangular dentiform projection. Uropod 3: inner ramus nearly reaching tip of article two of outer ramus.

\section{Description}

BoDy (Figs 3A, 4A, 5A). Very broad, very calcified, smooth, glossy, without dorsal carina; somites of pereion and pleonites $1-2$ without posterior bump.

HEAD (Fig. 6A-C). Lateral cephalic lobes large, triangular, distally subacute (males) or blunt (females).

EYES (Fig. 6A). Very elongate, lower part anteriorly and posteriorly slightly dilated (broader than upper part), dark, not fading in alcohol.

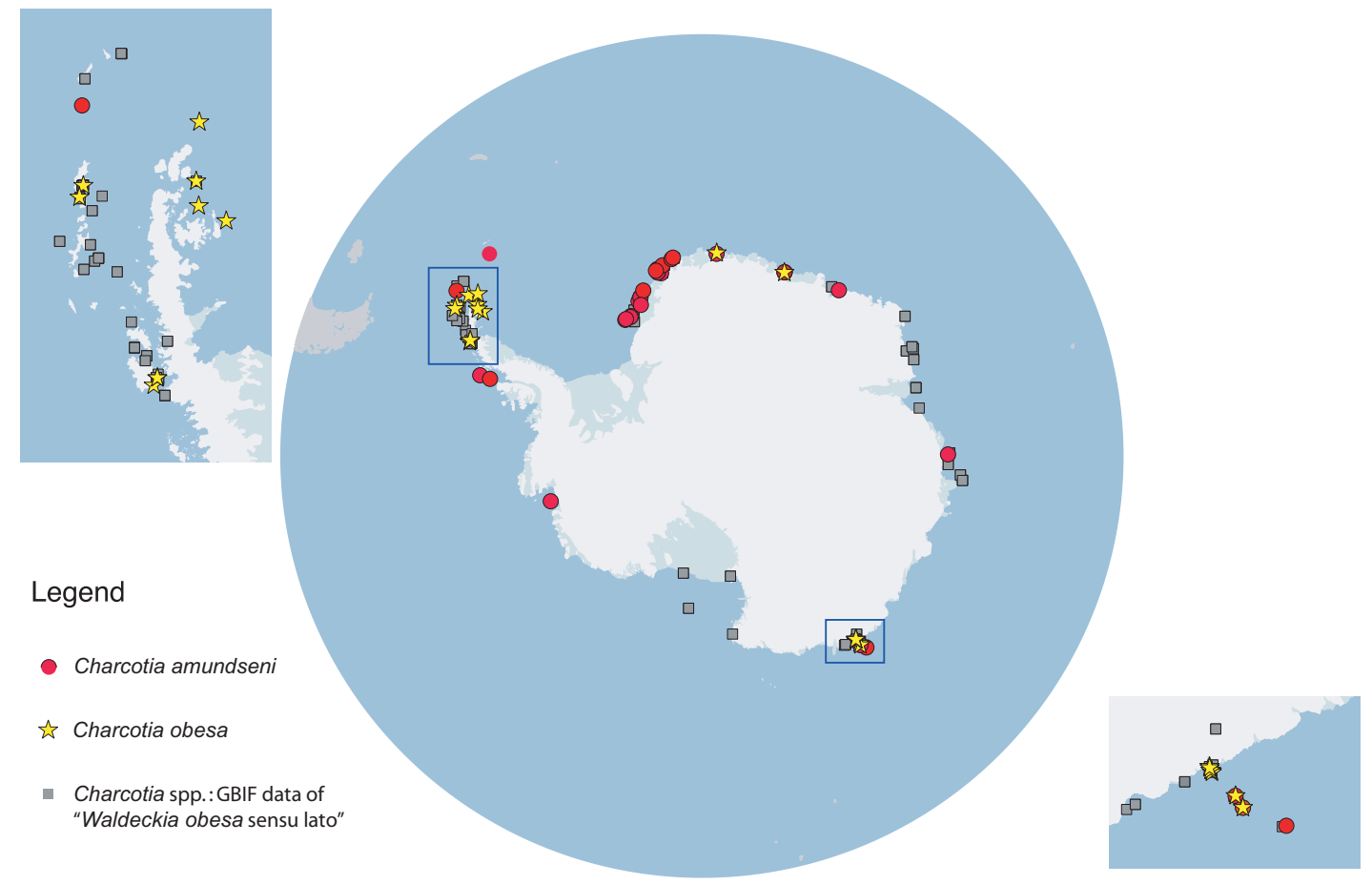

Fig. 2 - Distribution map of Antarctic species of Charcotia. Red dots: records of Charcotia amundseni sp. nov. (literature and new data combined). Yellow stars: records of Charcotia obesa Chevreux, 1906 (reliable literature and new data combined). Grey squares: GBIF (Global Biodiversity Information Facility) records of "Charcotia obesa sensu lato". 

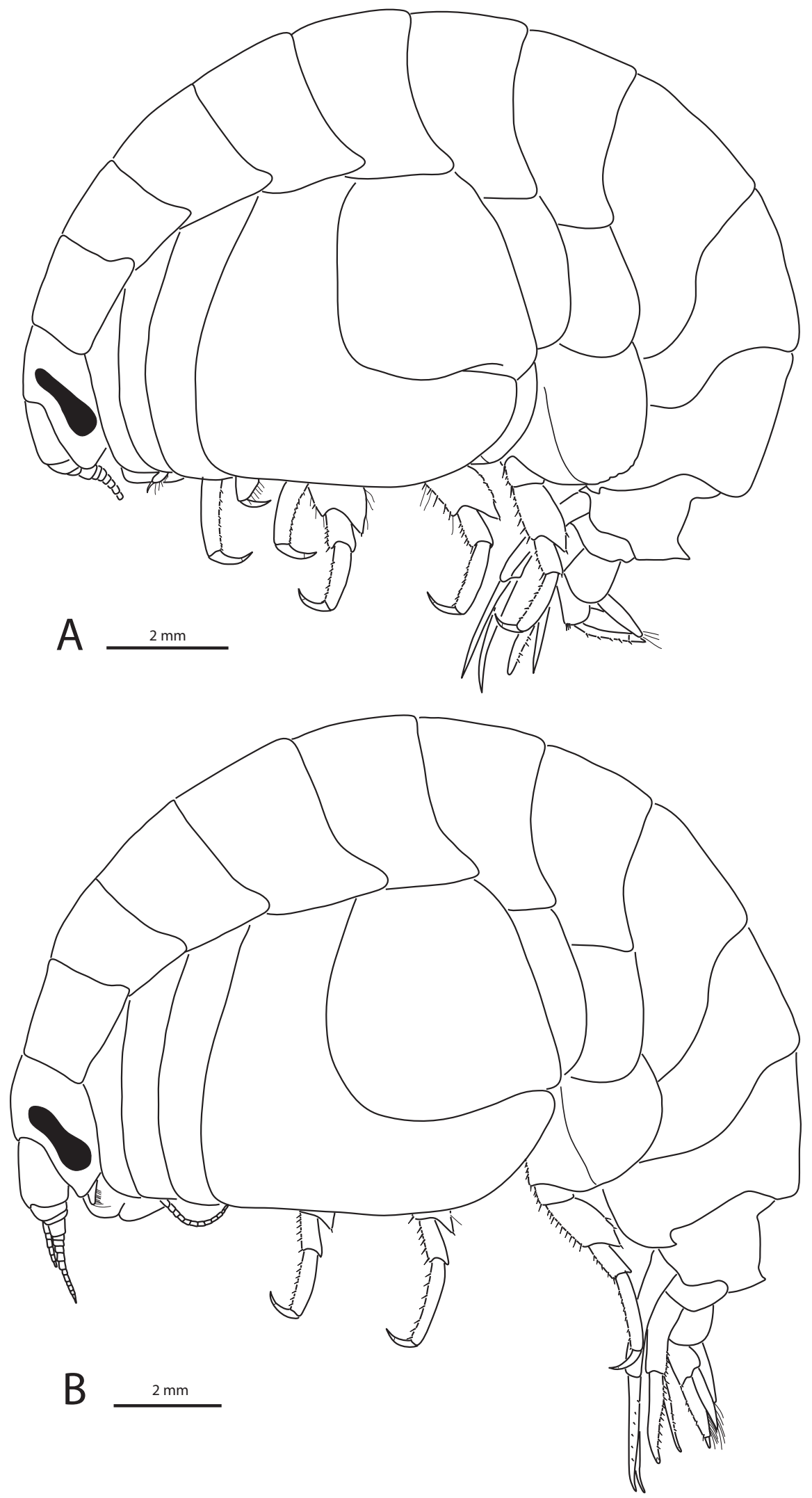

Fig. 3 - Charcotia spp. habitus (line drawings). A. C. amundseni sp. nov., holotype, female, Adélie Coast, CEAMARC sample 3226, stn 20, event 490 (MNHN-IU-2016-8908, DNA extraction W06). B. C. obesa (Chevreux, 1905), male, Adélie Coast, stn REVO_048-REVO_220 (MNHN-IU-2016-3832, DNA extraction W12). 


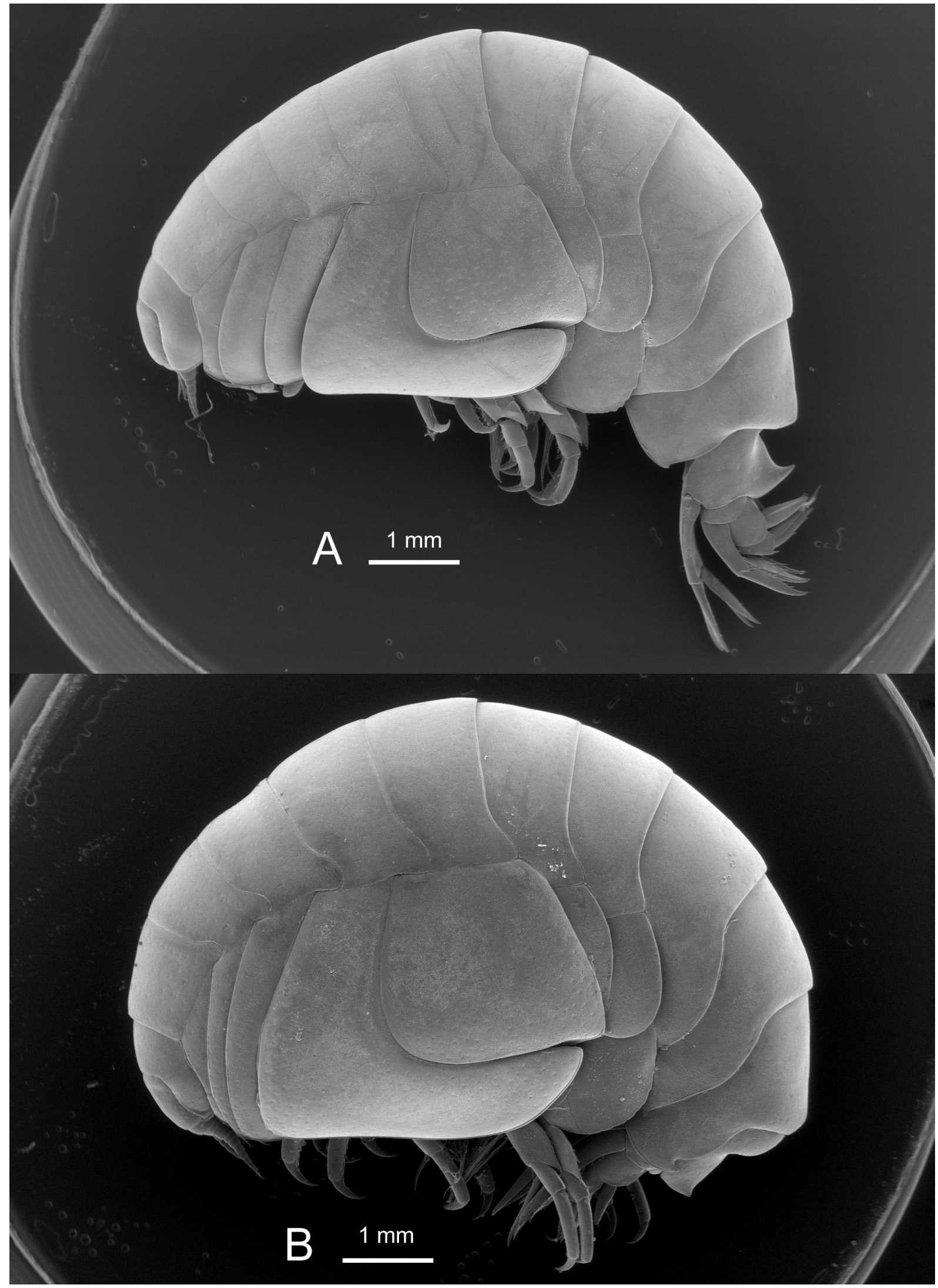

Fig. 4 - Charcotia spp. habitus (SEM). A. C. amundseni sp. nov., paratype, female, ANT-XV/3, East Weddell Sea, trap T9 (RBINS INV. 132836). B. C. obesa (Chevreux, 1905), female, ARC94, Admiralty Bay, NA60 (RBINS INV. 132809). 


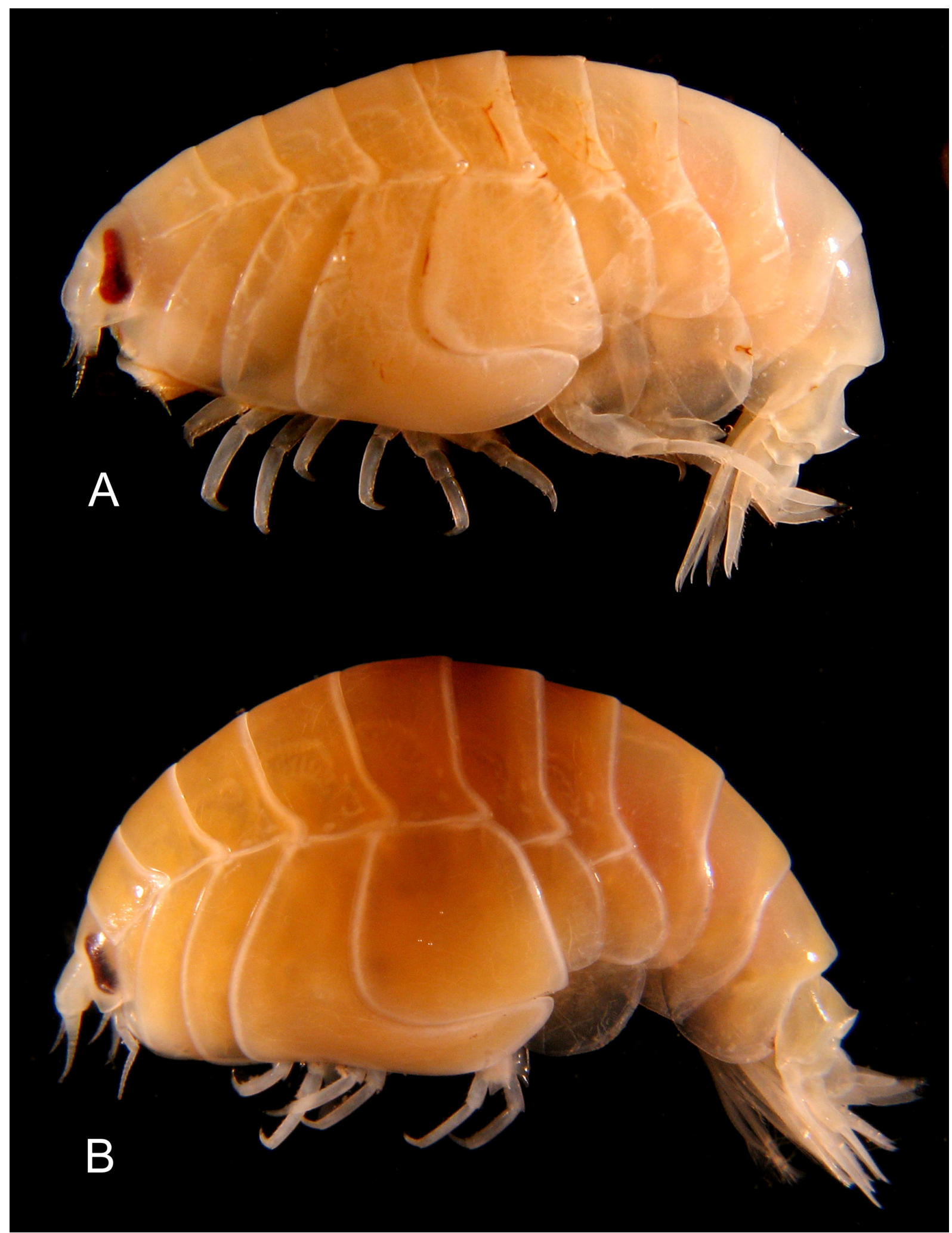

Fig. 5 - Charcotia spp. habitus (colour in life). A. C. amundseni sp. nov., paratype, sex indeterminate, ANT-XXIII/8, Elephant Island, stn 654-6 (RBINS INV. 122228). B. C. obesa (Chevreux, 1905), sex indeterminate, ANT-XXIII/8, Bransfield Strait, stn 686-1 (RBINS INV. 122439). 
ANTENNA 1 (Figs 6A, 7A-A'). About as long as antenna 2 (females and immature males) or much shorter than antenna 2 (adult males); peduncular article 1 very robust, 1.4 times as long as wide, without anterodistal projection; major flagellum, article 1 as long as articles 2-4 combined; accessory flagellum, article 1 as long as article 2 and 3 combined.

ANTENNA 2 (Figs 6A, 7B). Less than 10\% of body length in females and immature males, $90-110 \%$ of body length in adult males.

EPISTOME/UPPER LIP COMPLEX (Fig. 6A, D-F). Forming a laterally compressed, blade-shaped heavily calcified structure; epistome concave, upper lip rounded and protruding forward; connection between epistome and upper lip not forming a sinus.

MANDIBLE (Fig. 7D-G). Incisor process, cutting edge smooth and broad; lacinia mobilis present on left side only, spoon-shaped; four raker spines present, posteriorly followed by a crest coated with capillary setae connecting to and merging with molar process; molar process large, triangular, obliquely oriented inwards and posteriorly broad, densely coated with capillary setae, triturative surface reduced to small halfmoon-shaped patch situated at the tip of the molar process; palp 3-articulate, attached on proximal 0.3 , well proximal to molar process; article 1 without setae, article 2 longest with row of about 19 strong

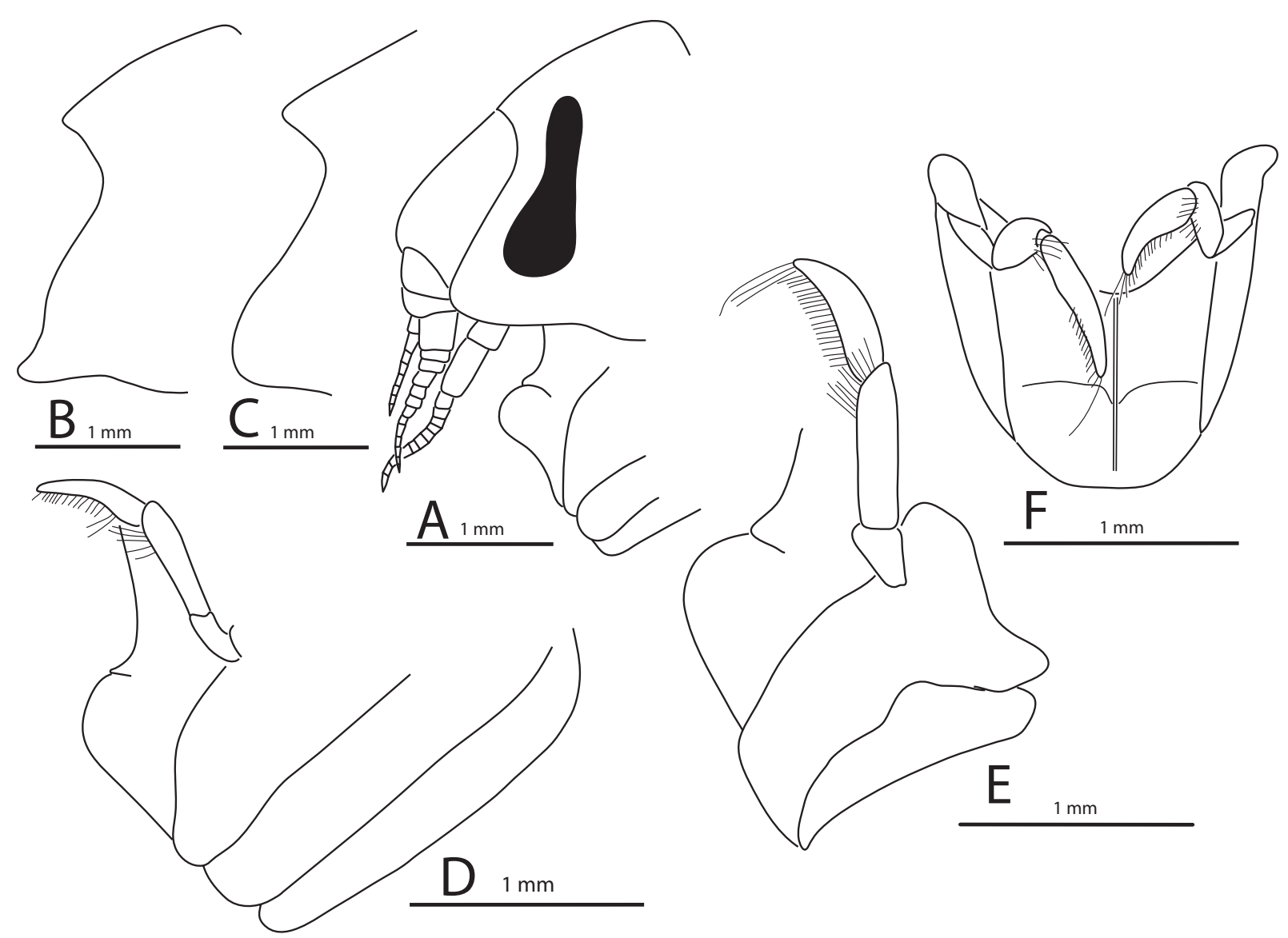

Fig. 6 - A-L. Charcotia amundseni sp. nov. A, D. Immature female, paratype, CEAMARC, Adélie Coast, sample 3477, stn 84, event 520 (MNHN-IU-2016-6552, DNA extraction W04). B-C. Paratypes (B = mature male; $\mathrm{C}=$ mature female), ANT-XV/3, trap T9 (RBINS INV. 132799). E-F. Mature male, paratype, ANT-XV/3, trap T9 (RBINS INV. 132837). A. Head. B-C. Lateral cephalic lobe. D. Epistome, lips, left Md, left Mx1 (lateral view). E. Epistome, lips, left Md (lateral view). F. Epistome, upper lip, left and right Md (frontal view). 
distal and subdistal A2-setae, articles 2 and 3 of palp subequal, not expanded, article 3 with row of about 30 D3-setae on distal 0.8 and two E3-setae on tip, with facial surface coated with capillary setae.

LOWER LIP (Fig. 7C). Tip of lobes densely coated with capillary setae.

MAXILLA 1 (Fig. 8A-C). Inner plate moderately elongate, with two apical setae; outer plate with 11 blade-shaped spines (in 8/3 arrangement) with a serrated edge; palp 2-articulate, broad with distal margin straight and lined by a row of 14 tiny nodular spines.

MAXILLA 2 (Fig. 8D, D', E, E'). Plates very narrow, tapering towards tip, distally setose; inner plate shorter and narrower than outer plate.

MAXILLIPED (Fig. 8F-G). Inner and outer plates well developed; inner plate fairly narrow, about $2 / 3$ the length of outer plate, with numerous strong setulose setae on distal and medial border, three short apical nodular spines (difficult to see); outer plate nearly reaching tip of article 3 of palp, with distal and inner margin lined by a row of tiny and very short nodular spines; palp well developed.

GNATHOPOD 1 (Fig. 9A-C). Coxa large but slightly shorter than coxa 2, subrectangular, anterior and posterior margins nearly straight and parallel, ventral margin broad, antero- and postero-ventral corners rounded; basis robust, with slender setae on anterior margin, with posterior margin smooth; ischium, merus and carpus scarcely longer than wide; propodus elongate, nearly pediform, without palm, with anterior and posterior borders nearly straight and converging, proximal width 2.5 times as long as distal width, 2.2 times as long as wide, posterior border with small subdistal tooth pointing forward, anterior and posterior margin with transverse groups of setae but without spines; dactylus well developed, robust and strongly curved, 0.4 times as long as propodus.

GNATHOPOD 2 (Figs 9D, 10). Coxa large but slightly shorter than coxa 3, subrectangular; anterior margin weakly convex and posterior margin straight; basis linear and narrow, nearly as long as all more distal articles combined; ischium linear and 3.4 times as long as wide; merus ovate and 1.8 times as long as wide, carpus 3.0 times as long as wide, 1.7 times as long as propodus, propodus/dactylus assemblage minutely subchelate, propodus rounded, two times as long as wide, profusely setose, posterior corner of palm weakly crenulate, not projecting beyond dactylus; dactylus fairly short, transverse.

PEREIOPOD 3 (Fig. 11). Coxa large, about as long as coxa 4, subrectangular, with anterior margin convex and posterior margin concave; leg neither especially stout nor especially slender; basis hairless or nearly so, ischium, merus and carpus with many long setae posteriorly; posterior border of propodus with nine short spines or pairs of short spines; dactylus normally developed, curved, with long unguis.

PEREIOPOD 4 (Fig. 11B-B'). Coxa as deep as wide, posteroventral lobe narrow and extremely long, anterior border slightly convex connecting to ventral border by well-defined right angle, ventral border straight on anterior half, convex (rounded) on posterior half (ventral border of posteroventral lobe); posteroventral lobe very long, as long as the more anterior part of the coxa, tip of posteroventral lobe rounded; leg neither especially stout nor especially slender; basis hairless or nearly so, ischium, merus and carpus with many long setae posteriorly; merus and carpus with anterodistal tuft of setae; propodus 4.3 times as long as wide, posterior border of propodus with nine short spines or pairs of short spines; dactylus normally developed, robust, curved, with long unguis, 0.36 times as long as propodus.

PEREIOPOD 5 (Fig. 11C). Coxa encased in the $270^{\circ}$ angle formed by the posterior border and the posteroventral lobe of coxa 4 , about as wide as deep, subquadrate (borders slightly diverging in a ventral direction), anterior border very slightly convex, posterior border nearly straight, anteroventral corner broadly rounded, posteroventral corner very bluntly angular; basis bluntly rectangular, slightly broader than long with anterior border forming a blunt angle on its distal 0.6 ; merus broad, with posterior border 


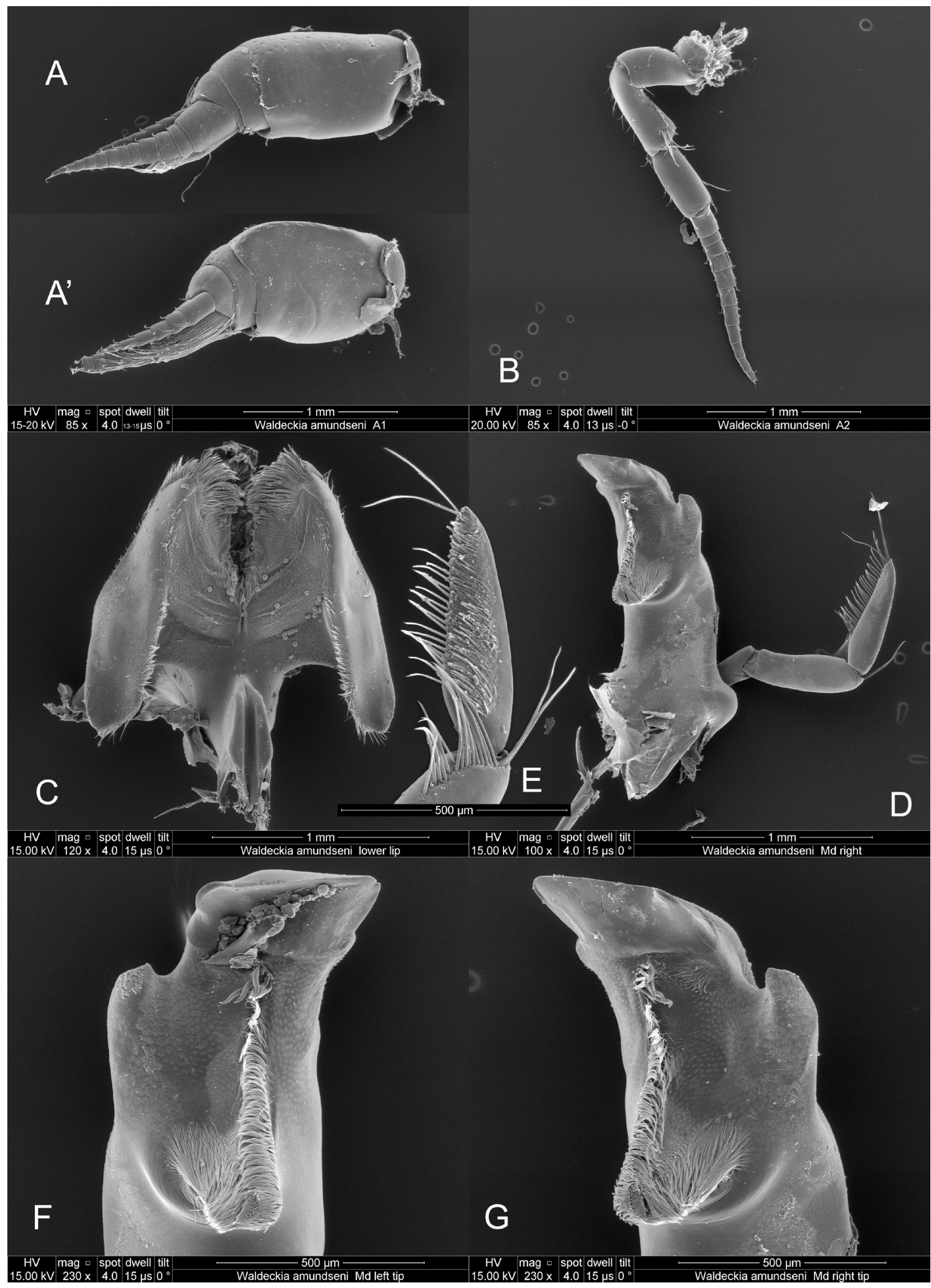

Fig. 7 - A-B, E. Charcotia amundseni sp. nov., paratype, immature female, CEAMARC, Adélie Coast, sample 3477, stn 84, event 520 (MNHN-IU-2016-6552, DNA extraction W04). C-D, F-G. Paratype, mature male, ANT-XV/3, trap T9 (RBINS INV. 132837). A. Left A1 (lateral view). A'. Right A1 (medial view). B. Left A2. C. Lower lip. D. Right Md. E. Tip of palp of left Md (facial view). F. Tip of left Md. G. Tip of right $\mathrm{Md}$. 


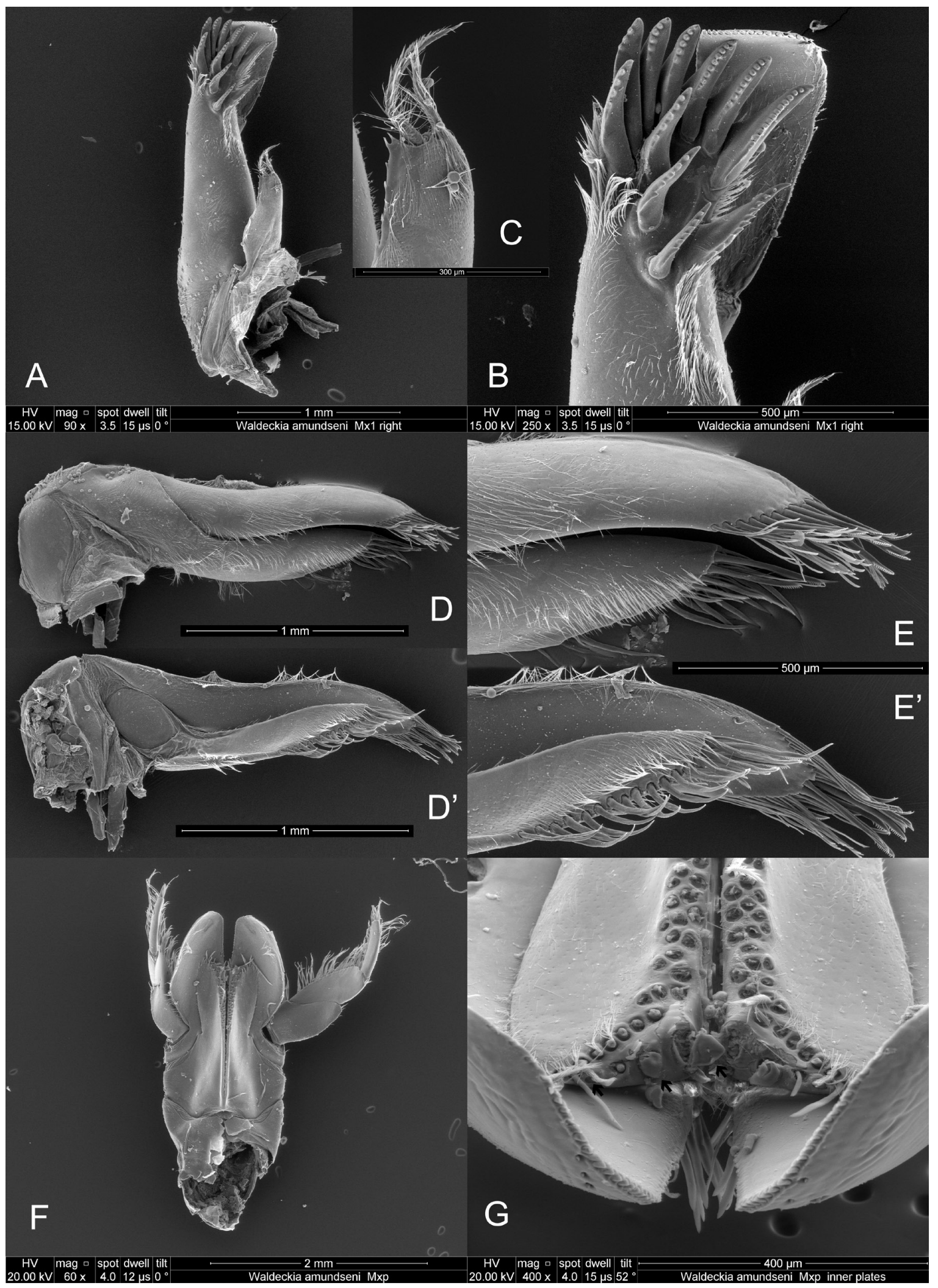

Fig. 8 - A-G. Charcotia amundseni sp. nov., paratype, mature male, ANT-XV/3, trap T9 (RBINS INV. 132837). A. Right Mx1. B. Outer plate and palp of right Mx1. C. Tip of inner plate of right Mx1. D. Right Mx2 (facial side). D'. Left Mx2 (oral side). E. Tip of right Mx2 (facial side). E'. Tip of left Mx2 (oral side). F. Mxp (setae of inner plates removed). G. Mxp plates (setae removed; nodular spines of distal margin of right inner plate indicated by arrows). 
setose and posterodistally terminated by a small spine; propodus 3.3 times as long as wide, anterior border with five pairs of short spines; dactylus normally developed, robust, curved, with long unguis, 0.6 times as long as propodus.

PEREIOPOD 6 (Fig. 11D-E). Coxa rectangular, anterior border 1.4 times as deep as wide, 1.1 times as long as basis, posterior border nearly straight (proximally very slightly convex); basis 1.1 times as long as wide, with anterior and posterior border convex on proximal half, straight on distal half and strongly converging in distal direction, posterodistal border produced into a broad, well-developed rounded lobe; merus broad, posterior border with short spines; propodus 4.6 times as long as wide, anterior border with six pairs of short spines; dactylus normally developed, robust, curved, 0.4 times as long as propodus.

PEREIOPOD 7 (Fig. 11F-G). Coxa looking like a round-tipped heater shield or kite attached to body by the posterior half of the "upper border of the shield", slightly longer than broad, 0.8 times as long as basis; basis 1.1 times as long as broad, with 15 very short spines or groups of spines anteriorly, about 10 weak crenellations posteriorly, anterior border weakly convex on proximal 0.25 , straight on distal 0.75 ,

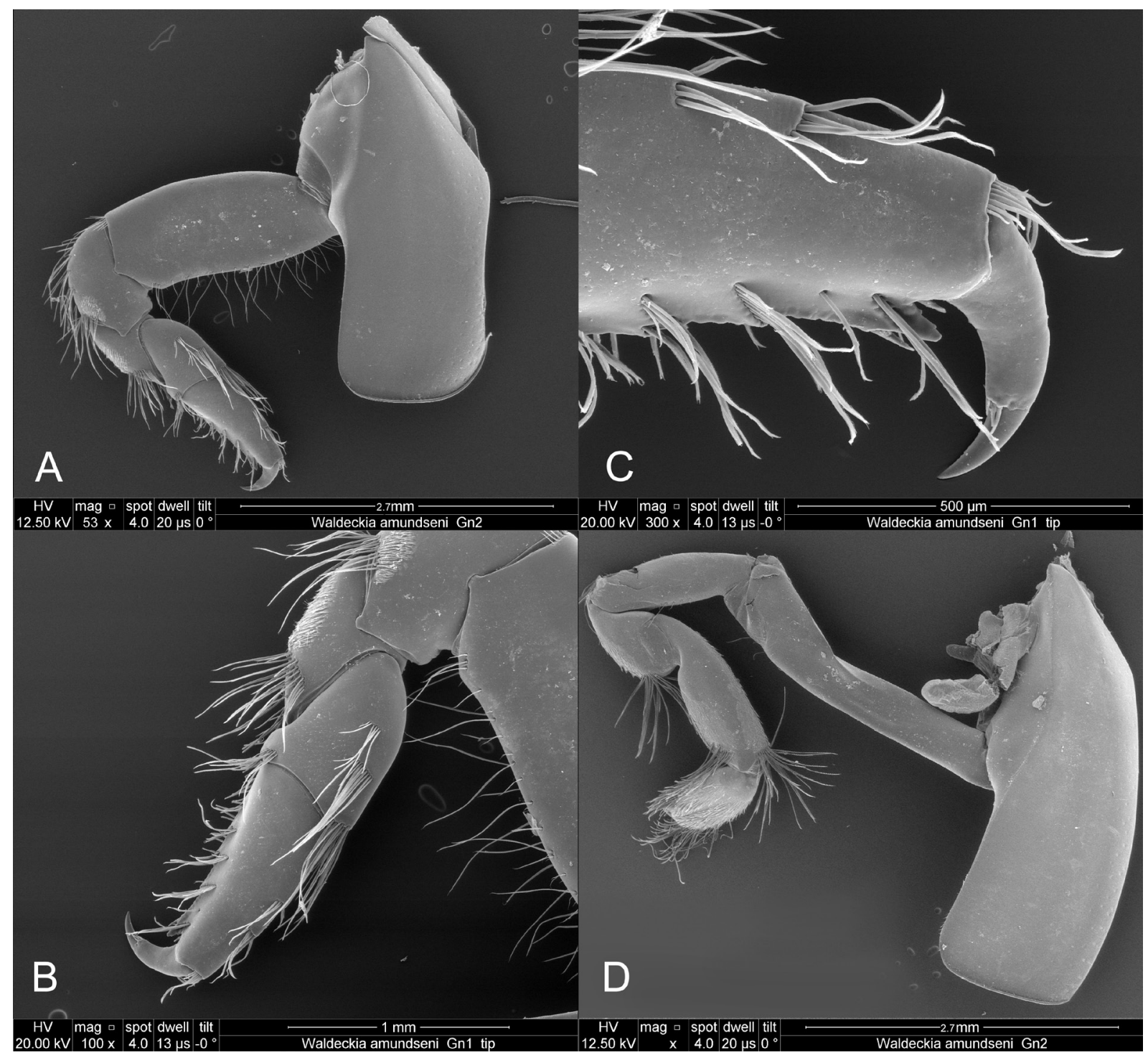

Fig. 9 - Charcotia amundseni sp. nov., paratype, immature female, CEAMARC, Adélie Coast, sample 3477, stn 84, event 520 (MNHN-IU-2016-6552, DNA extraction W04). A. Right Gn1. B. Distal half of right Gn1. C. Chela of right Gn1. D. Right Gn2. 

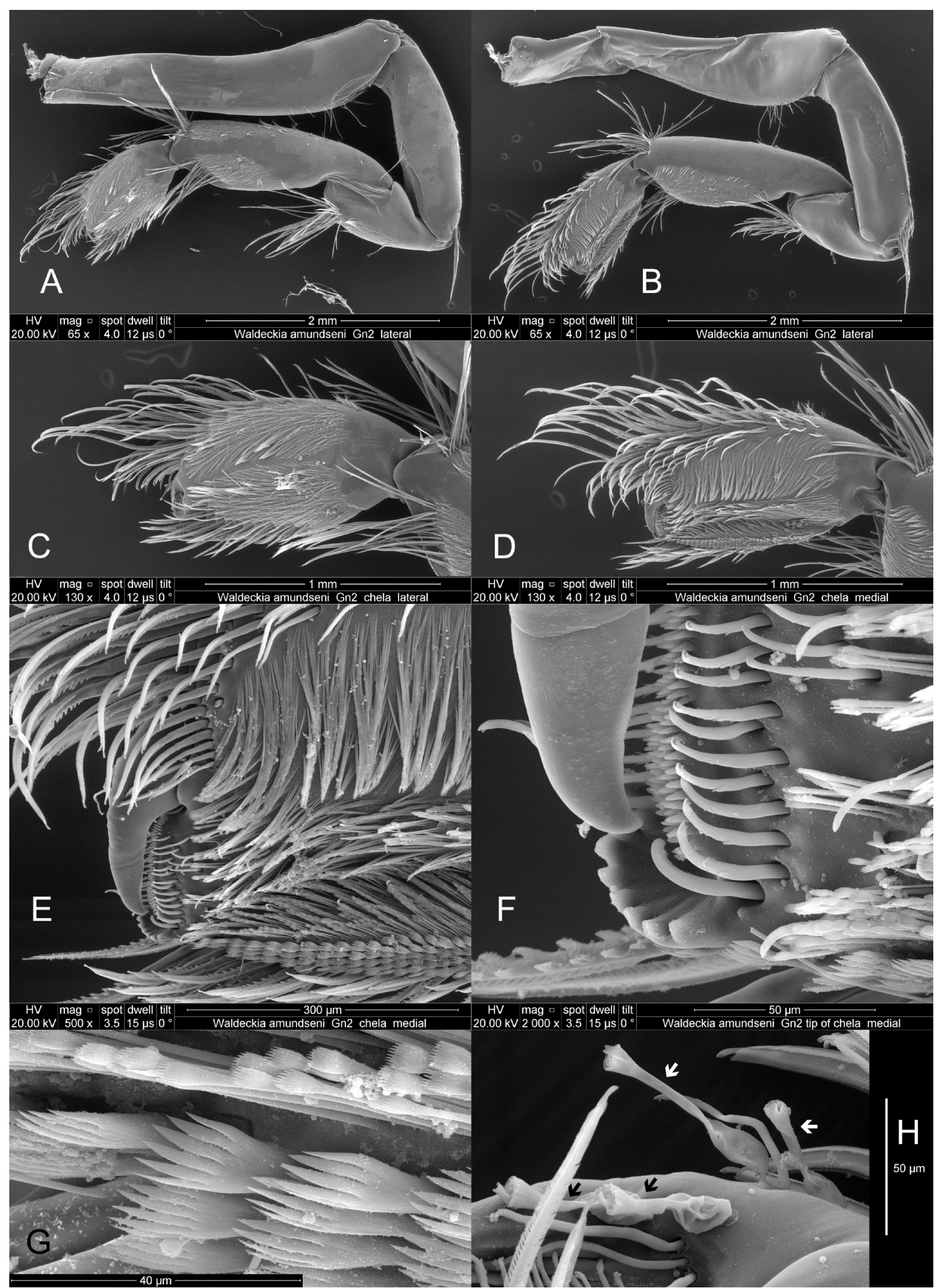

Fig. 10 - Charcotia amundseni sp. nov., paratype, mature male, ANT-XV/3, trap T9 (RBINS INV. 132837). A. Left Gn2 (lateral view). B. Right Gn2 (medial view). C. Chela of left Gn2 (lateral view). D. Chela of of right Gn2 (medial view). E. Dactylus and palm of right Gn2 (medial view). F. Tip of dactylus and posterior corner of palm of right Gn2 (medial view). G. 'Chiromorphic' setae of the posterior border of propodus of right $\mathrm{Gn} 2$ (medial view). H. Ciliate protozoans (indicated by arrows) on the dactylus of left Gn2 (lateral view). 


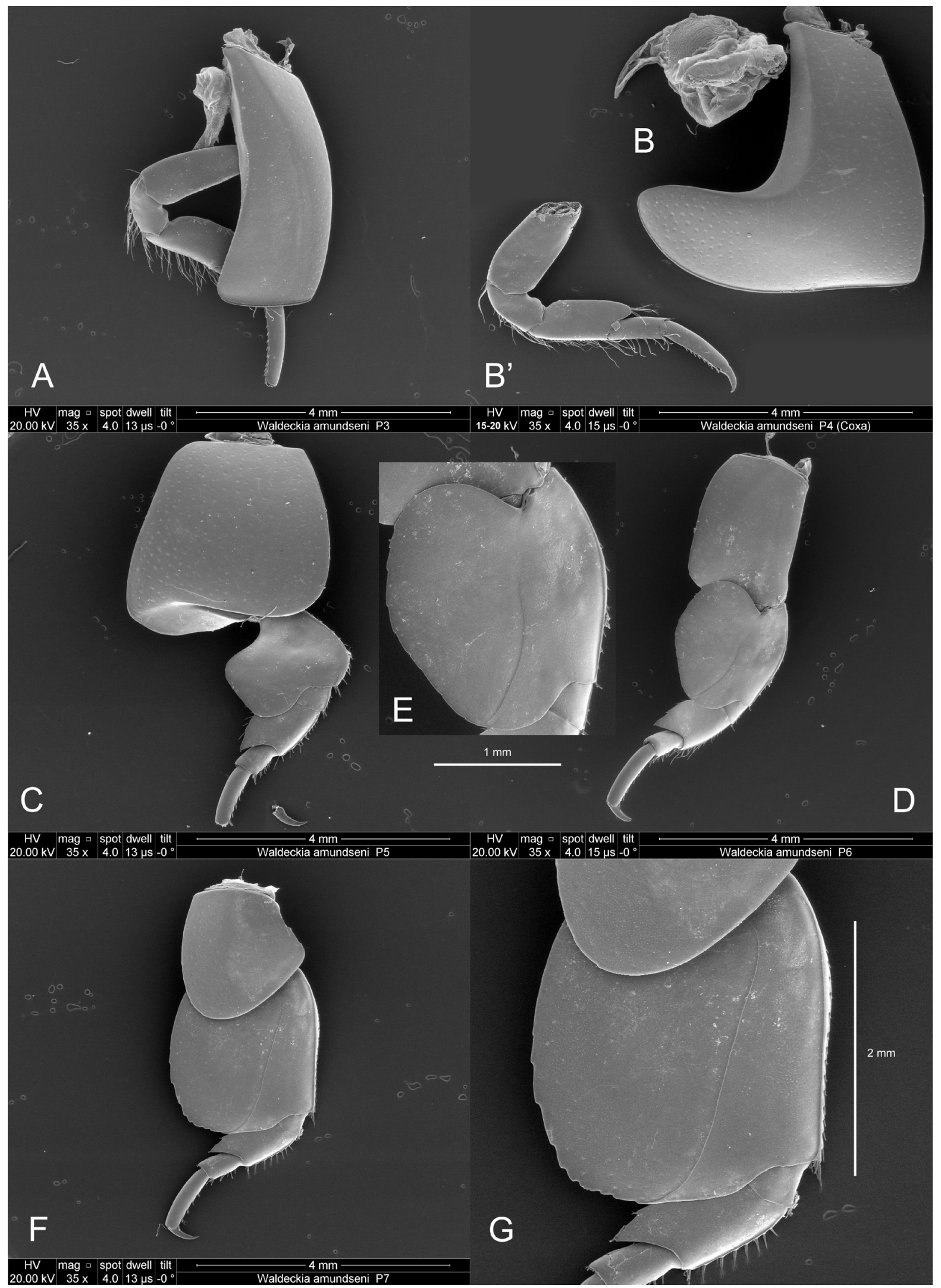

Fig. 11 - Charcotia amundseni sp. nov., paratype, immature female, CEAMARC, Adélie Coast, sample 3477, stn 84, event 520 (MNHN-IU-2016-6552, DNA extraction W04). A. Right P3. B. Right P4 (coxa). B'. Right P4 (leg). C. Right P5 (dactylus detached). D. Right P6. E. Basis of right P6. F. Right P7. G. Basis of right $\mathrm{P} 7$. 
posterodistal border very slightly convex (nearly straight), not projecting into a distal lobe, posterior border weakly convex, junction between posterodistal and posterior border forming a blunt angular discontinuity; merus fairly broad, posterior border with short spines; propodus 3.9 times as long as broad, anterior border with five pairs of short spines; dactylus normally developed, robust, curved, with long unguis, 0.5 times as long as propodus.

PLEONITE 1 (Fig. 12A). Epimeron anteroventral corner produced into a blunt-tipped triangular projection pointing forward; ventral and posterior borders forming a regular curve.

PLEONITE 2 (Fig. 12A). Epimeron anteroventral corner rounded, ventral border straight, posteroventral corner forming a sharp right angle terminated by a small triangular tooth; posterior margin sinuate (upper part convex, lower part straight).

PleONite 3 (Figs 12B, 13). Epimeron anteroventral corner rounded, ventral border weakly convex, posteroventral corner forming a tooth of which the shape and sharpness is variable but which is always small, posterior margins slightly convex; posterodorsal tip of pleonite forming a blunt right angle.

UROSOMITE 1 (Figs 12C-D, 13). Anteriorly with strong rounded elevation, followed by a low and nearly straight carina, terminating into a tooth pointing upwards, which is usually long and fairly narrow but which sometimes consists of a small triangular dentiform projection. Proximal part of carina with unispaths disposed in longitudinal grooves.

UROPOD 1 (Fig. 14A-B). Peduncle 1.3 times as long as inner ramus, with only one dorsolateral (tiny) spine (which is situated in distal position), and seven long and slender dorsomedial spines (of which 6 are situated on proximal 0.4 and the last one in distal position); outer ramus 1.1 times as long as inner ramus, with seven small dorsolateral spines and no dorsomedial spines; inner ramus with four small dorsolateral spines and five small dorsomedial spines.

UROPOD 2 (Fig. 14C). Peduncle as long as inner ramus, with nine dorsolateral spines of size increasing towards tip (proximal ones very small), with 10 regularly-spaced, dorsomedial setae followed by a long distomedial spine; outer ramus 1.04 times as long as inner ramus, with 12 well-developed dorsolateral spines and no dorsomedial spines; inner ramus with four well-developed dorsolateral spines and five small dorsomedial spines.

UROPOD 3 (Fig. 14D-E). Peduncle ordinary, about 0.77 times as long as outer ramus; outer ramus article one with seven lateral spines or pairs of lateral spines, 24 medial long plumose setae, article two 0.22 times as long as article one; inner ramus almost reaching tip of article 2 of outer ramus, with three lateral spines followed by three or four long lateral plumose setae, with about 20 long medial plumose setae.

TELSON (Fig. 12E-F). Elongate, cleft 0.85 of length, each lobe with three apical spines, without dorsolateral spines.

\section{Colour pattern (Fig. 5A)}

Uniformly white, yellowish, or pale yellow; eyes dark reddish brown.

\section{Measurements}

The body length of one of the largest specimens examined was $28 \mathrm{~mm}$. Both sexes reach similar sizes.

\section{Taxonomic decisions}

Variations in the development of the urosomal process of Charcotia obesa s.l. were pointed out by THURSTON (1974, as 'Waldeckia obesa'). He illustrated a form with an obtusely triangular urosomal process and one with the same process prolongated into an acute tooth. In analysing COI sequences 


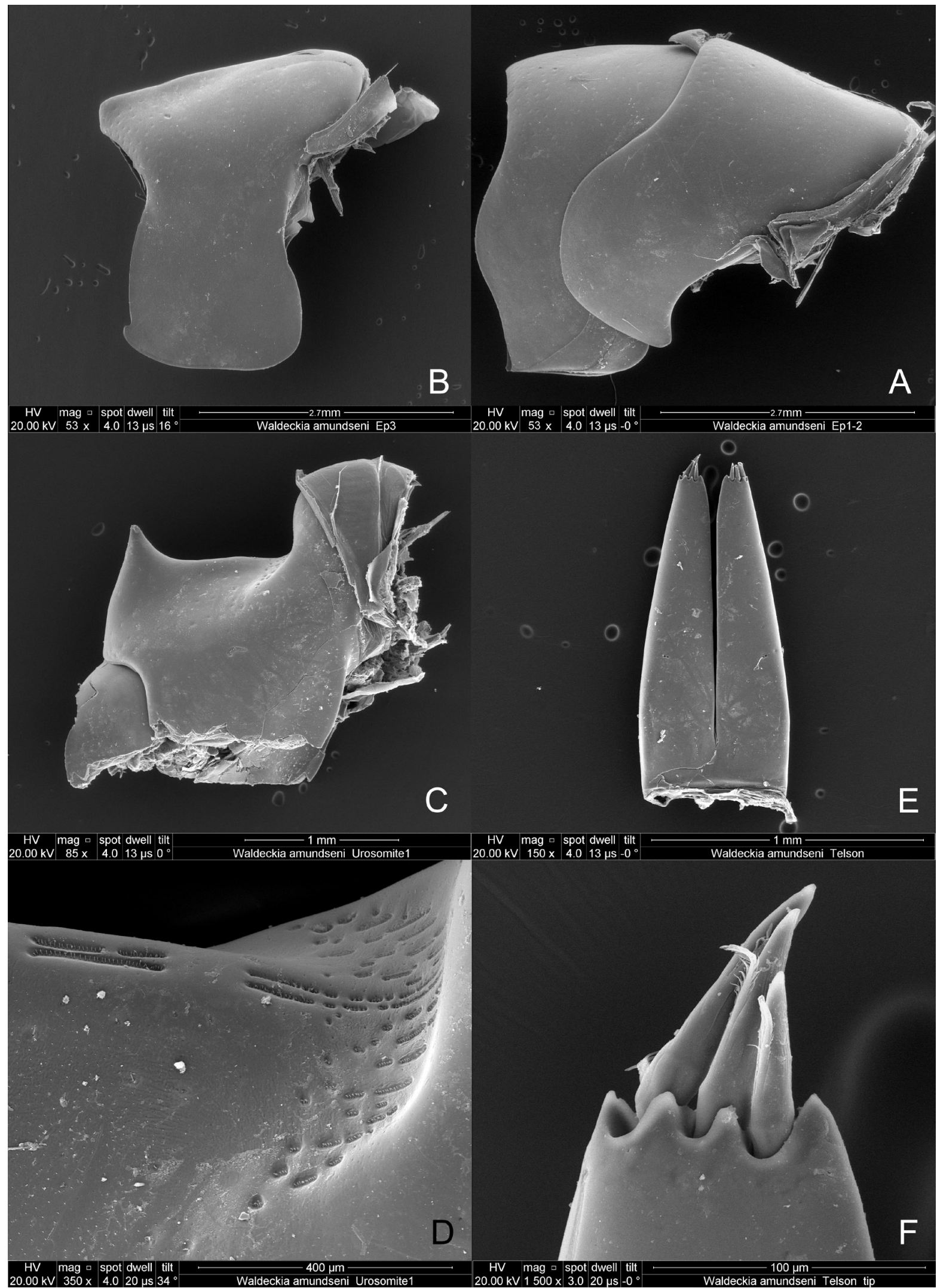

Fig. 12 - Charcotia amundseni sp. nov., paratype, immature female, CEAMARC, Adélie Coast, sample 3477, stn 84, event 520 (MNHN-IU-2016-6552, DNA extraction W04). A. Pleonites 1-2. B. Pleonite 3. C. Urosomite 1. D. Detail of the dorsal notch of urosomite 1 (tilted) - note the disposition of the unispathal pits. E. Telson. F. Tip of right lobe of telson. 

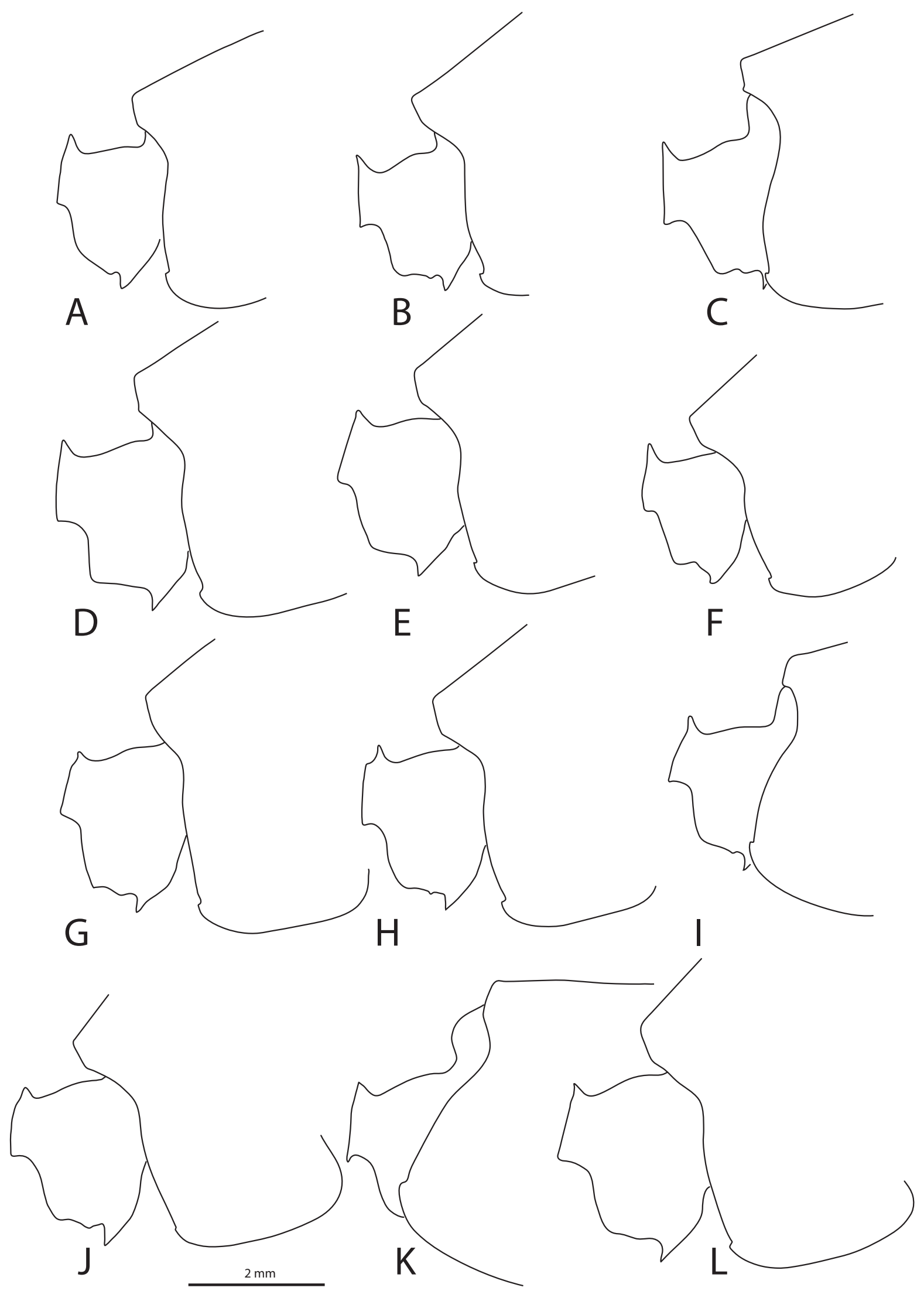

Fig. 13 - A-L. Charcotia amundseni sp. nov., paratypes, large adults (D, I-J, L = males; A-B, C, E-F, $\mathrm{K}=$ females; $\mathrm{G}-\mathrm{H}=$ sex not recorded), ANT-XV/3, trap T9 (RBINS INV. 132799). Variation in pleonite 3 (tooth of posteroventral corner) and urosomite 1. 


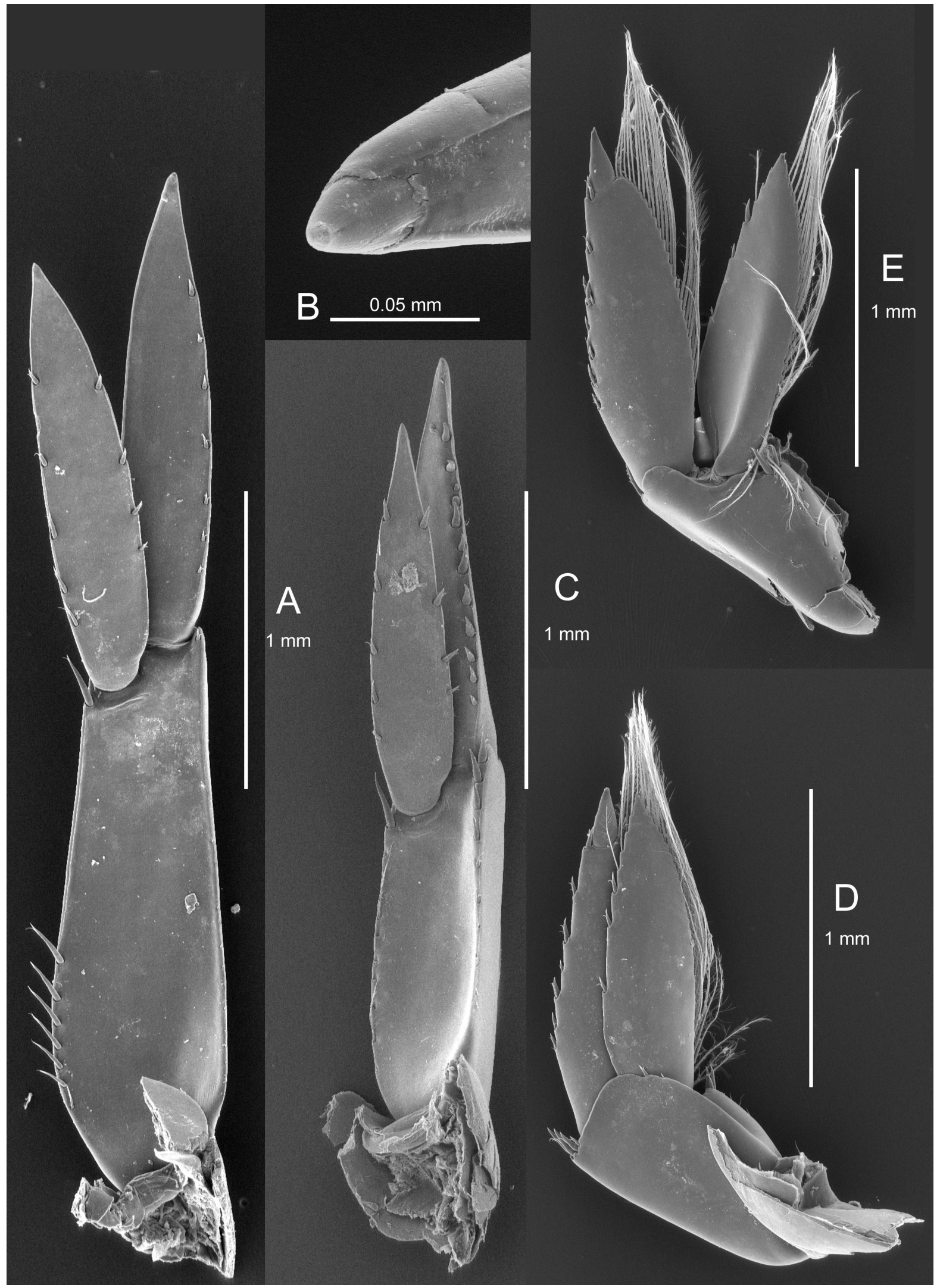

Fig. 14 - Charcotia amundseni sp. nov., paratype, immature female, CEAMARC, Adélie Coast, sample 3477, stn 84, event 520 (MNHN-IU-2016-6552, DNA extraction W04). A. Left U1 (dorsal view). B. Left U1 (tip of inner ramus). C. Left U2 (dorsal view). D. Right U3 (dorsal view). E. Left U3 (ventral view). 
of Charcotia obesa, HAVERMANS (2014, as 'Waldeckia obesa') recognized two clades separated by important genetic distances and overlapping geographical distributions. Our molecular analyses based on COI sequences confirm the existence of these two clusters and indicate a good correlation between the clades and the two urosomal morphotypes of THURSTON (1974). The morphology of urosomite 1 exhibits some level of variation in the two clades (especially the clade including specimens with an acute urosomal process), but several other more constant differences were detected, such as the development of the tooth of epimeron 3 and the shape of the basis of pereiopods 6 and 7 . The species with an obtusely triangular process perfectly conforms with the illustrations of one of the two syntypes of Charcotia obesa given by CHEVREUX (1906a, b), which is designated herein as the lectotype of C. obesa (see section on that species). The other species (i.e., the one with a sharper process) should be considered as new. It is described herein as Charcotia amundseni sp. nov.

\section{Distribution}

Amundsen Sea, Adelaide Island, Elephant Island, South Orkney Islands, East Weddell Sea, Enderby Land, Adélie Coast (present material), Lützow-Holm Bay (NAGATA, 1986, as 'Waldeckia obesa'), between 140-1241 m (present material). Exceptionally found at depths as shallow as $9 \mathrm{~m}$ (NAGATA, 1986, as 'Waldeckia obesa'). New and literature records are mapped on figure 2. Charcotia amundseni sp. nov. is a circum-Antarctic species. Its bathymetric distribution extends much deeper than for C. obesa and, unlike the latter, it is very rarely found in shallow-water.

\section{Biology}

In females and immature males of $C$. amundseni sp. nov., antenna 2 is very short whereas in mature males it is very long, reaching $90-110 \%$ of body length. BLUHM et al. (2001a, as 'Waldeckia obesa') estimated a maximum age of up to eight years for females [their material was collected between 400 and $800 \mathrm{~m}$, i.e., in a depth range where we only found C. amundseni sp. nov.]. Most of the material of 'Waldeckia obesa'studied by DAUBY et al. (2001b) has been re-examined and all these specimens belong to $C$. amundseni sp. nov. These authors made the following statements, based on their own observations: "In aquaria, individuals stay upright motionless on the bottom or on sessile animals, with antennae slowly investigating the surrounding water. Experiments have shown that $W$. obesa is very sensitive to carrion odour, and reacts rapidly by swimming when any piece or drop of carrion is put in its container. As mentioned previously for some Abyssorchomene species, swarms of W. obesa are able to attack and eat moribund fishes (especially scaleless icefishes). Stomach content analyses were performed on specimens collected by trawl. Stomachs are long and large, able to store huge quantities of food. About one third of them were empty but the others were filled almost exclusively with organic material, hardly recognizable and variously coloured, wherein fragments of striated muscles could be distinguished. $W$. obesa was collected in $80 \%$ of the baited trap deployments [in the eastern Weddell Sea], often in large numbers (up to 2730 specimens). (...) The emptiness of many stomachs should suggest that $W$. obesa is rather well adapted to a discrete way of feeding, alternating periods of fasting and gluttony."

Charcotia obesa Chevreux, 1906

Figs 1-2, 3B, 4B, 5B, 15-22

Charcotia obesa Chevreux, 1906a: 163, fig. 3.

Charcotia obesa - WALKER, 1906: 451 (at least in part).

Waldeckia obesa - CHEVREUX, 1906b: 15, fig. 8-10. - WALKER, 1907: 10 (at least in part), pl. 2 fig. 4. - Bellisio \& TOMO, 1974: 77, unnumbered fig. p. 82. - THURSTON, 1974: 64, in part, fig. 25a-b (not 25c). - KLAGES, 1991: 98 (in part), unnumbered figs. — REN \& HuANG, 1991: 255, fig. 43. - De Broyer et al., 2007: 134, in part (ubi syn.). - LOWRY \& Kilgallen, 2014: 304, 332. - SCHORIES \& KOHLBERG, 2016: 188 (in part). — SEEFELDT et al. 2017: 8, fig. $2 \mathrm{~h}$. 
Waldeckia obesa cluster A. - SEEFELDT et al. 2017: 9.

Waldeckia zschauii - CHILTON, 1912: 471, in part (RSS Discovery material only).

Waldeckia zschaui. - CHILTON, 1913: 56, in part (RSS Discovery material only).

Orchomene arnaudi Bellan-Santini, 1972: 205, fig. 22.

Waldeckia robusta Ren in Ren \& Huang, 1991: 255, 310, figs 44-45.

Waldeckia sp. - SCHORIES \& KOHLBERG 2016: 189, unnumbered photograph.

non Anonyx zschauii Pfeffer, 1888: 87, pl. 2 fig. 1 (= Orchomenella (Orchomenopsis) zschauii (PFEFFER, 1888)).

\section{Type locality}

Biscoe Bay, Anvers Island, lat. 6450' S, 110 m (see below: section 'taxonomical decisions').

\section{Material examined}

ANTARCTIC: 1 specimen, Cruise CEAMARC, Adélie Coast, sample V3 3156, stn 17, event 485, $66.169132^{\circ} \mathrm{S}, 139.932052^{\circ} \mathrm{E}$ to $66.174595^{\circ} \mathrm{S}, 139.989905^{\circ} \mathrm{E}, 140-152 \mathrm{~m}$, beam trawl, $15 \mathrm{Jan} .2008$ (MNHN-IU-2016-6569, extraction H. Robert W03, GenBank nr MH078074). —1 specimen, sample 3226 , stn 20 , event $490,65.989378^{\circ} \mathrm{S}, 139.994898^{\circ} \mathrm{E}$ to $66.01644^{\circ} \mathrm{S}, 140.000462^{\circ} \mathrm{E}, 189-196 \mathrm{~m}$, beam trawl, 15 Jan. 2008 (MNHN-IU-2016-3828, extraction H. Robert W09, sequencing not yet successful). 1 specimen, sample 3226, stn 20, event 490 (same coordinates) (MNHN-IU-2016-3822, extraction H. Robert W10, GenBank nr MH078067). — 1 specimen, sample 3226, stn 20, event 490 (same coordinates) (MNHN-IU-2016-3829, extraction H. Robert W11, sequencing not successful). - 50 specimens, Expedition REVOLTA I (winter campaign), Adélie Coast, fishing hole [trou de pêche-REVO-099], stn REVO-099-543, exact coordinates unavailable, 21 May 2010, coll. J. Chevallier (MNHN-IU-2016-6203, extractions C. Havermans 269 to 316, specimens not separated). -6 adults, 1 juvenile and 3 hatchlings, fishing hole [trou de pêche-REVO-100], stn REVO-100-545, exact coordinates unavailable, year 2010, coll. J. Chevallier (MNHN-IU-2016-6223 [The sample includes a note written by (?) C. Havermans and indicating "two specimens removed Seefeldt 2014"]). - 34 specimens, $R V$ Seatruck, expedition REVOLTA II, Adélie Coast, stn REVO_133-REVO_133, 66³7'04.08" S, 14000'12.96" E, 103107 m, 11 Jan. 2011 (CE-000000726, MNHN-IU-2016-6435, extractions C. Havermans 71 to 103, specimens not separated). - 9 specimens (1 juvenile), stn REVO_062-REVO_154, 66 ${ }^{\circ} 36^{\prime} 06.12^{\prime \prime} \mathrm{S}$, $140^{\circ} 01^{\prime} 48^{\prime \prime}$ E, 130-131 m, 18 Jan. 2011 (MNHN-IU-2016-6244, extractions C. Havermans 137 to 144). - 1 specimen, stn REVO_017-REVO_173, 66 40'48.72" S, 139 58'13.8” E, 32-37 m, 24 Jan. 2011 (CE-0000001308, MNHN-IU-2016-6214, extractions C. Havermans 25 to 27 [it is not known if they are all based on the specimen examined or if there were initially two additional specimens]). - 1 specimen, stn REVO 017-REVO 173 (same coordinates) (MNHN-IU-2016-3830, extraction H. Robert W19, GenBank nr MH078075). — 1 specimen, stn REVO_017-REVO_173 (same coordinates) (MNHNIU-2016-3831, extraction H. Robert W20, GenBank nr MH078070). — 1 female (illustrated in toto), stn REVO_048-REVO_220, 66³7'59.88" S, 14001'21.36" E, 88-90 m, 4 Feb. 2011 (CE-0000001878, MNHN-IU-2016-3832, extraction H. Robert W12, GenBank nr MH078068). - 1 specimen, stn REVO_048-REVO_220 (same coordinates) (CE-0000001878, MNHN-IU-2016-3833, extraction H. Robert W13, GenBank nr MH078069). — 1 mature female (dissected, some parts on 16 stubs for SEM), stn REVO_048-REVO_220 (same coordinates) (CE-0000001878, MNHN-IU-2016-3834, extraction H. Robert W14, GenBank nr MH078073). — 1 specimen [urosomal process a bit unusual], stn REVO_048REVO_220 (same coordinates) (CE-0000001878, MNHN-IU-2016-3835, extraction H. Robert W15, sequencing not yet successful). - 1 specimen, stn REVO_048-REVO_220 (same coordinates) (CE-0000001878, MNHN-IU-2016-3836, extraction H. Robert W16, GenBank nr MH078072). 1 specimen, stn REVO_048-REVO_220 (same coordinates) (CE-0000001878, MNHN-IU-2016-3837, extraction $\mathrm{H}$. Robert $\mathrm{W} 17$, sequence acquired when analyses were terminated). -1 specimen, stn REVO_048-REVO_220 (same coordinates) (CE-0000001878, MNHN-IU-2016-6208, extraction H. Robert W18, GenBank nr MH078071). - 61 specimens (including 6 adult males with elongated 
second antennae), Expedition REVOLTA III (winter campaign), Adélie Coast, stn Jacobsen-REVO_552 (REVO-103-552), 66 39'54.7776" S, 139 59'32.1576" E, depth not given, but certainly shallowwater (? intertidal) [Google Earth (accessed 12 Apr. 2017) indicated 0 m depth], 13 May 2012, coll. J. Lanshere (MNHN-IU-2016-6469, extractions C. Havermans 323 to 386 (specimens not separated) [the reverse of the label written by (?) C. Havermans indicated "6 specimens removed SEEFELDT, 2014"]). 1 specimen, Expeditions antarctiques Belgo-Néerlandaises (EABN), station lost, Enderby Land, label incomplete, presumably from the sector including the Baie U.S.S. Glacier, the Bay King Léopold III, the Baie du Polarhav and the Baie Breid, years 1960-1966 (RBINS INV. 132817). — 2 specimens, stn 329, no precise lat/long coordinates, King Léopold III Bay, 170 m, baited trap, 26 Jan. 1966 (RBINS INV. 132824). - 800 specimens or more (20 examined in detail), Expedition ARCTOWSKI 87 (ARC87), King George Island, Admiralty Bay, coll. C. De Broyer, P. Schaltin \& V.N. Phan, stn N7, 62 $08^{\prime}$ S, 58 $27^{\prime}$ W, 70 m, 12-14 Jan. 1987 (RBINS INV. 132807). — 4 specimens, stn N7 (same coordinates) (RBINS INV. 132825). - 2 specimens, stn N7 (same coordinates) (RBINS INV. 132826). - 2 specimens, stn N7 (RBINS INV. 132827). - 1200 specimens or more, stn N8, 62 $08^{\prime} \mathrm{S}, 58^{\circ} 27^{\prime} \mathrm{W}$, 50 m, gear "NMØ7 n¹", 14-17 Jan. 1987 (RBINS INV. 132804). — 500 specimens or more, stn N8 (same coordinates) (RBINS INV. 132805). - 1000 specimens or more, stn N8 (RBINS INV. 132806). - 1000 specimens or more, stn N8 (same coordinates) (RBINS INV. 132830). - 50 specimens or more, stn CA3, 62 $08^{\prime} \mathrm{S}, 58^{\circ} 27^{\prime} \mathrm{W}, 80 \mathrm{~m}, 20$ Feb. 1987 (RBINS INV. 132829). - 150 specimens or more, Expedition ARCTOWSKI 88 (ARC88), King George Island, Admiralty Bay, coll. P. Presler, $62^{\circ} 08^{\prime} \mathrm{S}, 58^{\circ} 27^{\prime} \mathrm{W}$, stn 31, no depth, trap P03, 25 Feb. 1988 (RBINS INV. 132808). - 1 specimen, Expedition ARCTOWSKI 92 (ARC92), King George Island, Admiralty Bay, 62 $08^{\prime}$ S, 58 $27^{\prime}$ W, coll. G. Chapelle \& Y. Scailteur, aquarium, no depth indication, but probably shallow water, 6 Aug. 1992 (RBINS INV. 132786). - 1 specimen, same coordinates, 2 Apr. 1992: (RBINS INV. 132787). - 1 specimen, same coordinates, 10 Apr. 1992 (RBINS INV. 132788). - 1 specimen, same coordinates, aquarium (dead), 23 Apr. 1992 (RBINS INV. 132789). — 1 specimen, same coordinates, 7 Apr. 1992 (RBINS INV.132790). - 1 specimen, same coordinates, 1992 (RBINS INV. 132791). - 1 specimen, same coordinates, 1992, (RBINS INV. 132792). - 2 specimens, same coordinates, 10 Sep. 1992 (RBINS INV. 132793). - 1 specimen, same coordinates (RBINS INV.132794). - 1 large specimen, same coordinates (RBINS INV. 132795). - 700 specimens or more, Expedition ARCTOWSKI 94 (ARC 94), King George Island, Admiralty Bay, coll. C. De Broyer \& K. Jażdżewski, stn NA60, 62 $08^{\prime} \mathrm{S}, 58^{\circ} 27^{\prime} \mathrm{W}$, 200 m, baited trap, 22-25 Dec. 1993 (RBINS INV. 132801). - 1 specimen air-dried, mounted on stub and gold-coated for SEM (not dissected), stn NA60 (same coordinates) (RBINS INV. 132809). Maxilliped of one large male specimen, mounted on stub and gold-coated for SEM, stn NA60, same coordinates (RBINS INV. 132838). - 41 ovigerous females (the original global label indicates 43 ovigerous females) (each specimen isolated alive in a separate small vial), stn Na60/N93-39, $62^{\circ} 08^{\prime} \mathrm{S}$, $58^{\circ} 27^{\prime} \mathrm{W}, 200 \mathrm{~m}$, baited trap, 22 to 25 Dec. 1993 (RBINS INV. 132803). - 2 specimens, in alcohol $70^{\circ}, R V$ Polarstern, PS69, ANT-XXIII/8, coll. C. d'Udekem d'Acoz \& H. Robert, Bransfield Strait, stn $686-1,62^{\circ} 34.12^{\prime} \mathrm{S}, 55^{\circ} 26.66^{\prime} \mathrm{W}$ to $62^{\circ} 35.38^{\prime} \mathrm{S}, 55^{\circ} 23.67^{\prime} \mathrm{W}$, bottom trawl, $149 \mathrm{~m}, 4 \mathrm{Jan} .2007$ (RBINS INV. 122439). - 7 juveniles, photographed on board, initial fixation formalin, NW Weddell Sea, stn $726-1,64^{\circ} 30.86^{\prime} \mathrm{S}, 56^{\circ} 40.23^{\prime} \mathrm{W}$ to $64^{\circ} 31.16^{\prime} \mathrm{S}, 56^{\circ} 40.51^{\prime} \mathrm{W}, 197-199 \mathrm{~m}$, Rauschert dredge, 22 Jan. 2007 (RBINS INV. 122231). - 2 juveniles, initial fixation formalin, NW Weddell Sea, stn 728-2, $63^{\circ} 42.63^{\prime} \mathrm{S}, 56^{\circ} 01.63^{\prime} \mathrm{W}$ to $63^{\circ} 42.25^{\prime} \mathrm{S}, 56^{\circ} 02.16^{\prime} \mathrm{W}, 293-298 \mathrm{~m}$, Agassiz trawl, $24 \mathrm{Jan} .2007$ (RBINS INV. 122230). - 1 photograph (specimen currently unavailable), RV Polarstern, PS81, ANT-XXIX/3, LASSO, coll. C. d'Udekem d'Acoz \& M. Verheye, NW Weddell Sea, stn 160-3, 63 $10.57^{\prime}$ S, $54^{\circ} 6.66^{\prime} \mathrm{W}$ to $63^{\circ} 10.71^{\prime} \mathrm{S}, 54^{\circ} 6.37^{\prime} \mathrm{W}, 238-244 \mathrm{~m}$, Agassiz trawl, 8 Feb. 2013 (RBINS, amphipod photographic collection). - 1 photograph (specimen currently unavailable), NW Weddell Sea, stn 162-7, 63⒌78 ${ }^{\prime} \mathrm{S}$, 56 $46.24^{\prime} \mathrm{W}$ to $63^{\circ} 59.02^{\prime} \mathrm{S}, 56^{\circ} 46.26^{\prime} \mathrm{W}, 214-216 \mathrm{~m}$, Agassiz Trawl, 10 Feb. 2013 (RBINS amphipod photographic collection). 


\section{Differential diagnosis}

Epistome / upper lip complex: epistome strongly convex (rounded), upper lip anteriorly convex, posteriorly straight and very weakly protruding forward; connection between epistome and upper lip forming a deep V-shaped sinus. Pereiopod 5: coxa posteroventral corner forming a right angle; basis with anterior border broadly rounded. Pereiopod 6: basis posterodistal border broadly rounded; anterior and posterior borders not strongly convergent. Pereiopod 7: basis posterodistal border weakly but distinctly convex, projecting into a low distal lobe, junction between posterodistal and posterior border forming a curve with no real angular discontinuity. Pleonite 3: posteroventral corner of epimeron with strong tooth. Urosomite 1: posteriorly with small triangular dentiform projection pointing upwards. Uropod 3: inner ramus reaching base of article two of outer ramus.

\section{Description}

BoDy (Figs 3B, 4B, 5B). Very broad, very calcified, smooth, glossy, without dorsal carina; somites of pereion and pleonites 1-2 without small posterior bump.

HEAD (Figs 15A, 16A). Lateral cephalic lobes large, triangular, distally subacute (males) or blunt (females).

EYES (Fig. 15A). Very elongate, lower part anteriorly and posteriorly slightly dilated (broader than upper part), dark, not fading in alcohol.

ANTENNA 1 (Figs 15A, 16A-B). About as long as antenna 2 (females and immature males) or much shorter than antenna 2 (adult males); peduncular article 1 very robust, 1.6 times as long as wide, without anterodistal projection; major flagellum, article 1 as long as articles 2-4 combined; accessory flagellum, article 1 as long as article 2 and 3 combined.

ANTENNA 2 (Figs 15A, 16C). Less than 10\% of body length in females and immature males, $80 \%$ of body length in adult males.

EPISTOME/UPPER LIP COMPLEX (Fig. 15A-C). Forming a laterally compressed, blade-shaped heavily calcified structure; epistome strongly convex (rounded), upper lip convex (rounded) on anterior 0.2-0.3, straight on posterior $0.7-0.8$, scarcely protruding forward; connection between epistome and upper lip forming a deep V-shaped sinus.

MANDIBLE (Fig. 16E-F). Incisor process, cutting edge smooth and broad; lacinia mobilis present on left side only, spoon-shaped; four raker spines present, posteriorly followed by a crest coated with capillary setae connecting to and merging with molar process; molar process large, triangular, obliquely oriented inwards and posteriorly broad, densely coated with capillary setae, triturative surface reduced to small elliptic patch situated at the tip of the molar process; palp 3-articulate, attached on proximal 0.3 , well proximal to molar process; article 1 without setae, article 2 longest with row of strong distal and subdistal A2-setae, articles 2 and 3 of palp subequal, not expanded, article 3 with row of about 30 D3-setae on distal 0.8 and two E3-setae on tip.

LOWER LIP (Fig. 16D). Tip of lobes densely coated with capillary setae.

MAXILLA 1 (Fig. 17A-C). Inner plate moderately elongate, with five apical setae; outer plate with 11 blade-shaped spines (in 8/3 arrangement), which are denticulate on one side; palp 2-articulate, broad with distal margin straight and lined by a row of eight small nodular spines.

MAXILLA 2 (Fig. 17D, D', E, E'). Plates very narrow, tapering towards tip, distally setose; inner plate shorter and narrower than outer plate. 
MAXILLIPED (Fig. 17F). Inner and outer plates well developed; inner plate fairly narrow, about 2/3 the length of outer plate, with numerous strong setulose setae on distal and medial border, three short apical nodular spines (difficult to see); outer plate reaching mid of article 3 of palp, with distal and inner margin lined by a row of tiny and very short nodular spines; palp well developed.

GNATHOPOD 1 (Fig. 18A-C). Coxa large but slightly shorter than coxa 2, subrectangular, anterior and posterior margins nearly straight and parallel, ventral margin broad, antero- and postero-ventral corners rounded; basis robust, with slender setae on anterior margin, with posterior margin smooth; ischium, merus and carpus scarcely longer than wide; propodus elongate, nearly pediform, without palm, with anterior and posterior borders nearly straight and converging, proximal width two times as long as distal width, 2.9 times as long as wide, posterior border with small subdistal tooth pointing forward, anterior and posterior margin with transverse groups of setae but without spines; dactylus well developed, robust and strongly curved, 0.3 times as long as propodus.

GNATHOPOD 2 (Fig. 18D-F). Coxa large but slightly shorter than coxa 3, subrectangular; anterior margin weakly convex and posterior margin straight; basis linear and narrow, nearly as long as ischium, merus and carpus combined; ischium linear and 3.5 times as long as wide; merus ovate and 1.9 times as long as wide, carpus 3.4 times as long as wide, 2.0 times as long as propodus, propodus/dactylus assemblage
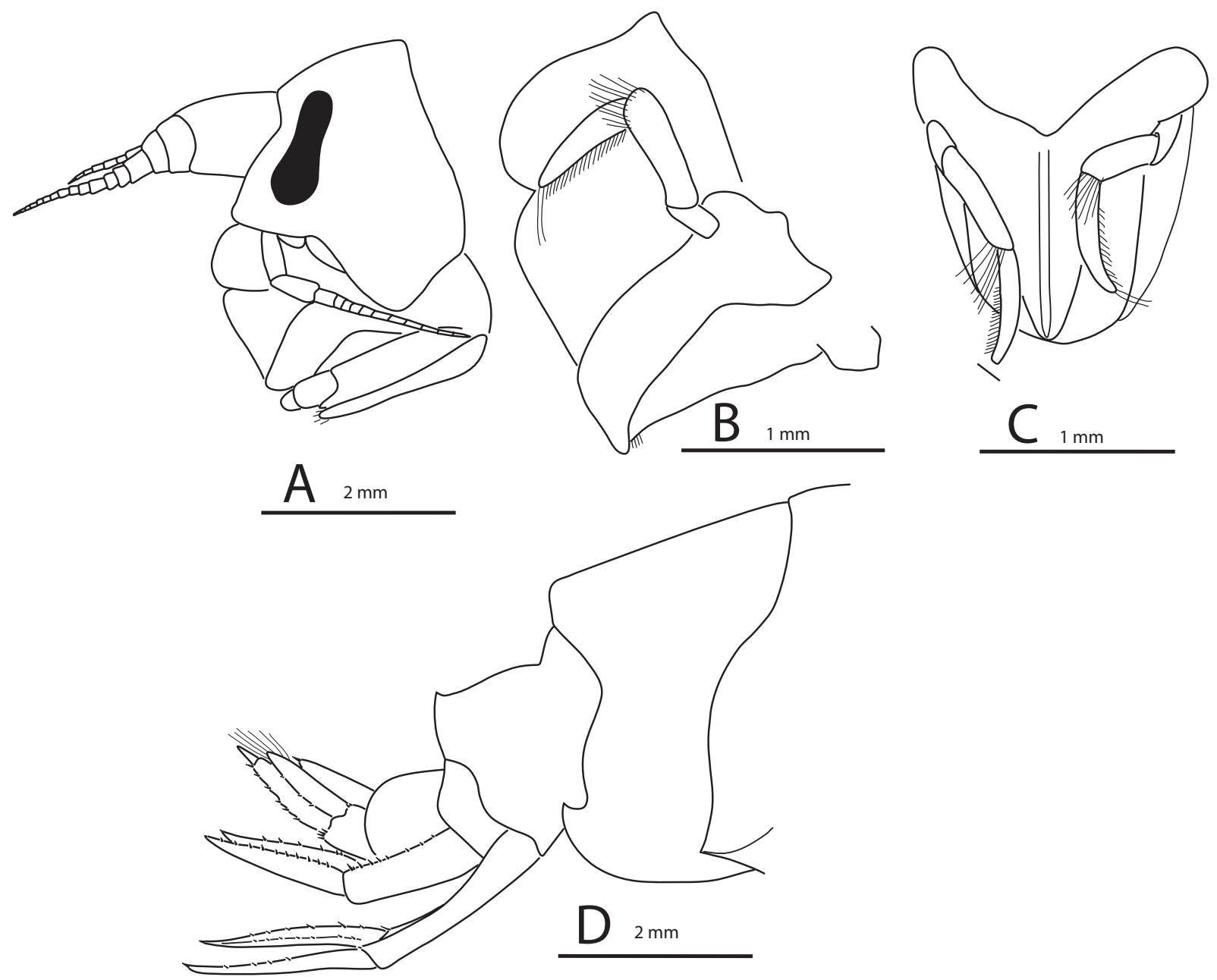

Fig. 15 - Charcotia obesa (Chevreux, 1906), mature female, REVOLTA II, stn REVO_048-REVO_220 (MNHN-IU-2016-3834, DNA extraction W14). A. Head with antennae and mouthparts (except Mxp). B. Epistome, upper lip, left Md, lower lip (lateral view). C. Epistome, upper lip, left and right Md (frontal view). D. Posterior half of pleon. 


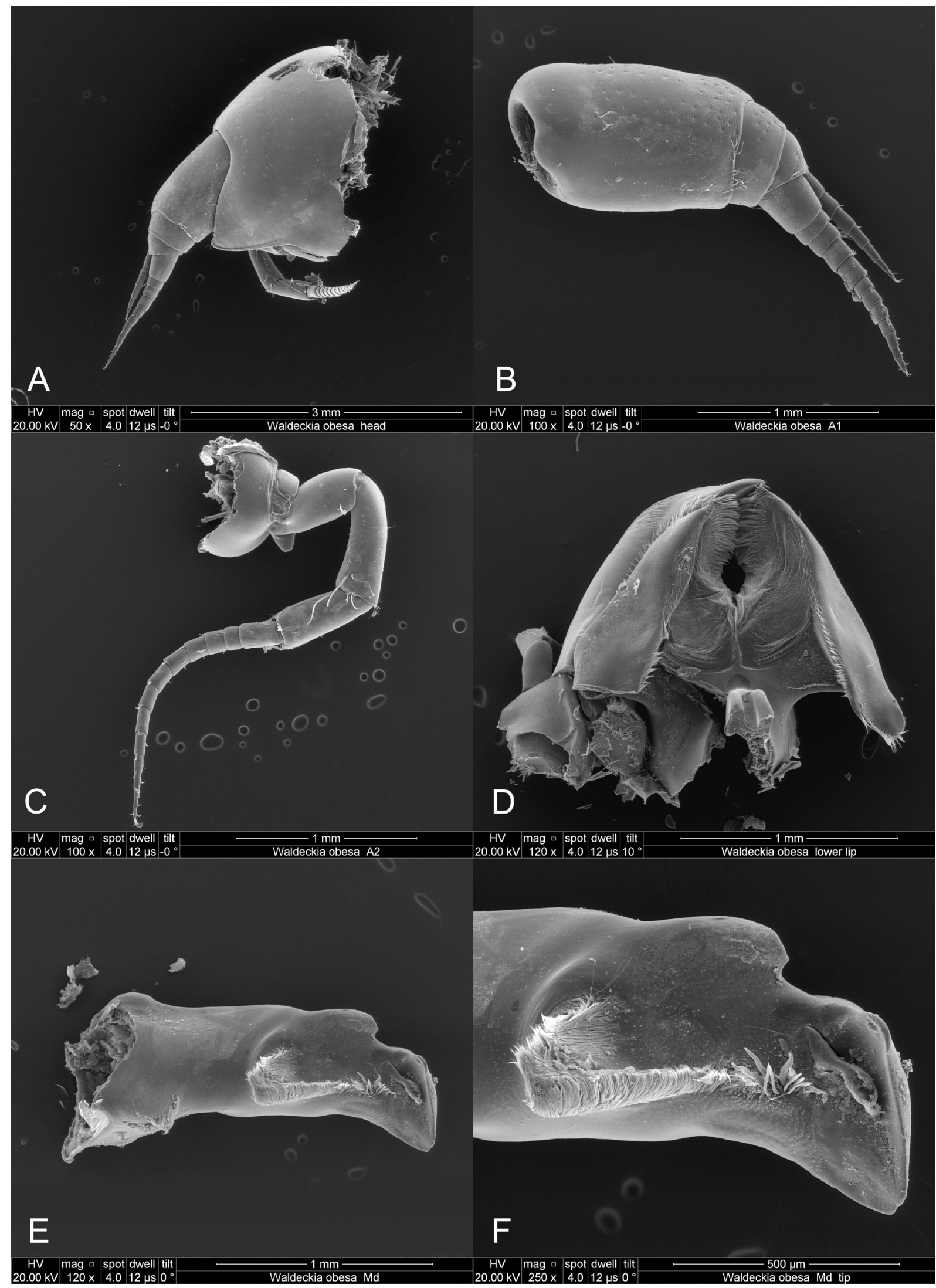

Fig. 16 - Charcotia obesa (Chevreux, 1906), mature female, REVOLTA II, stn REVO_048-REVO_220 (MNHN-IU-2016-3834, DNA extraction W14). A. Head. B. Right A1. C. Right A2. D. Lower lip (right mandible behind lip, not removed). E. Left mandible (palp lost). F. Distal half of left mandible. 


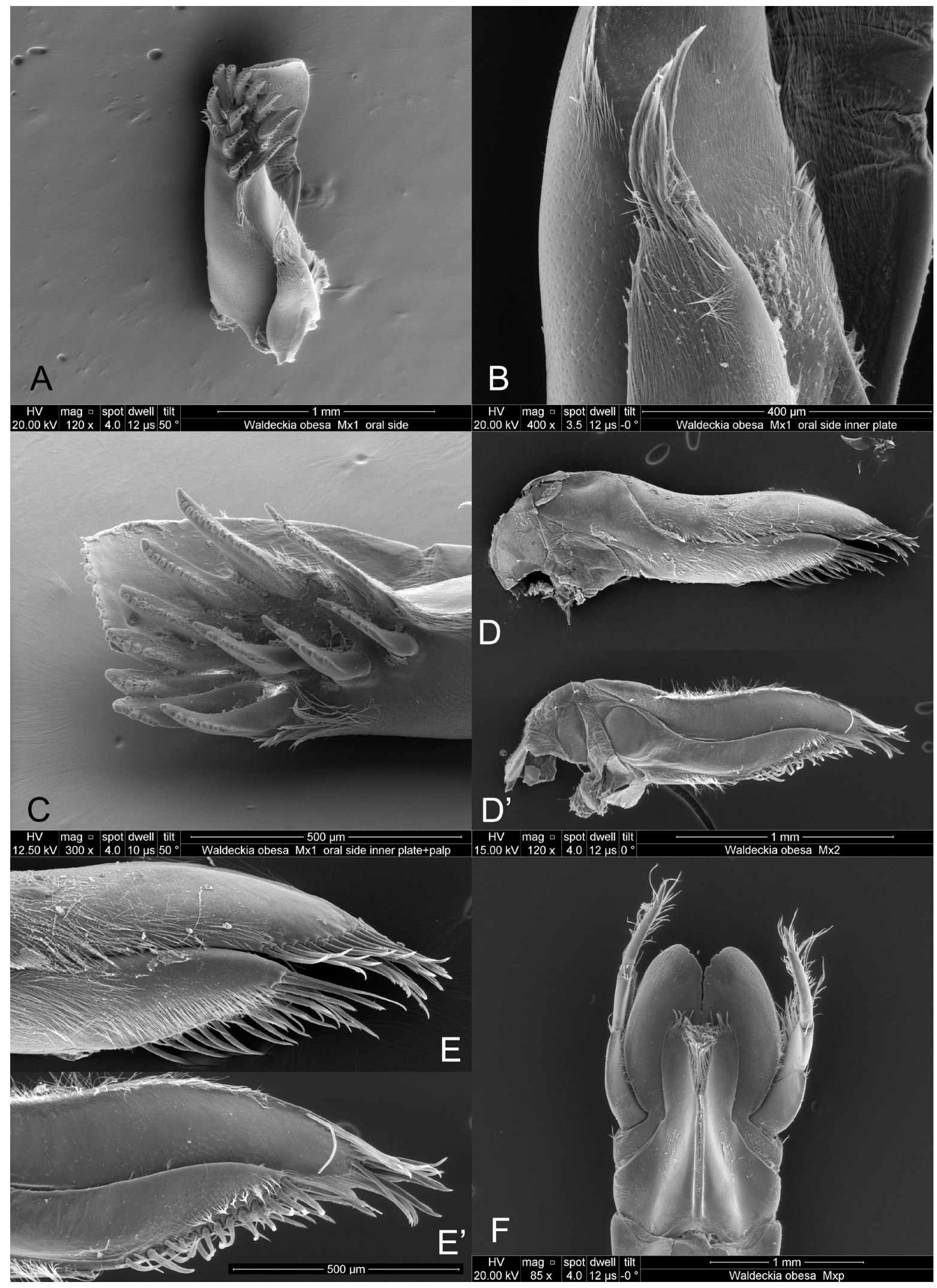

Fig. 17 - Charcotia obesa (Chevreux, 1906), mature female, REVOLTA II, stn REVO_048-REVO_220 (MNHN-IU-2016-3834, DNA extraction W14). A. Left Mx1 (oral side). B. Left Mx1 (tip of inner plate). C. Left Mx1 (tip of outer plate and palp). D. Right Mx2 (facial side). D'. Left Mx2 (oral side). E. Tip of right Mx2 (facial side). E'. Tip of left Mx2 (oral side). F. Mxp. 


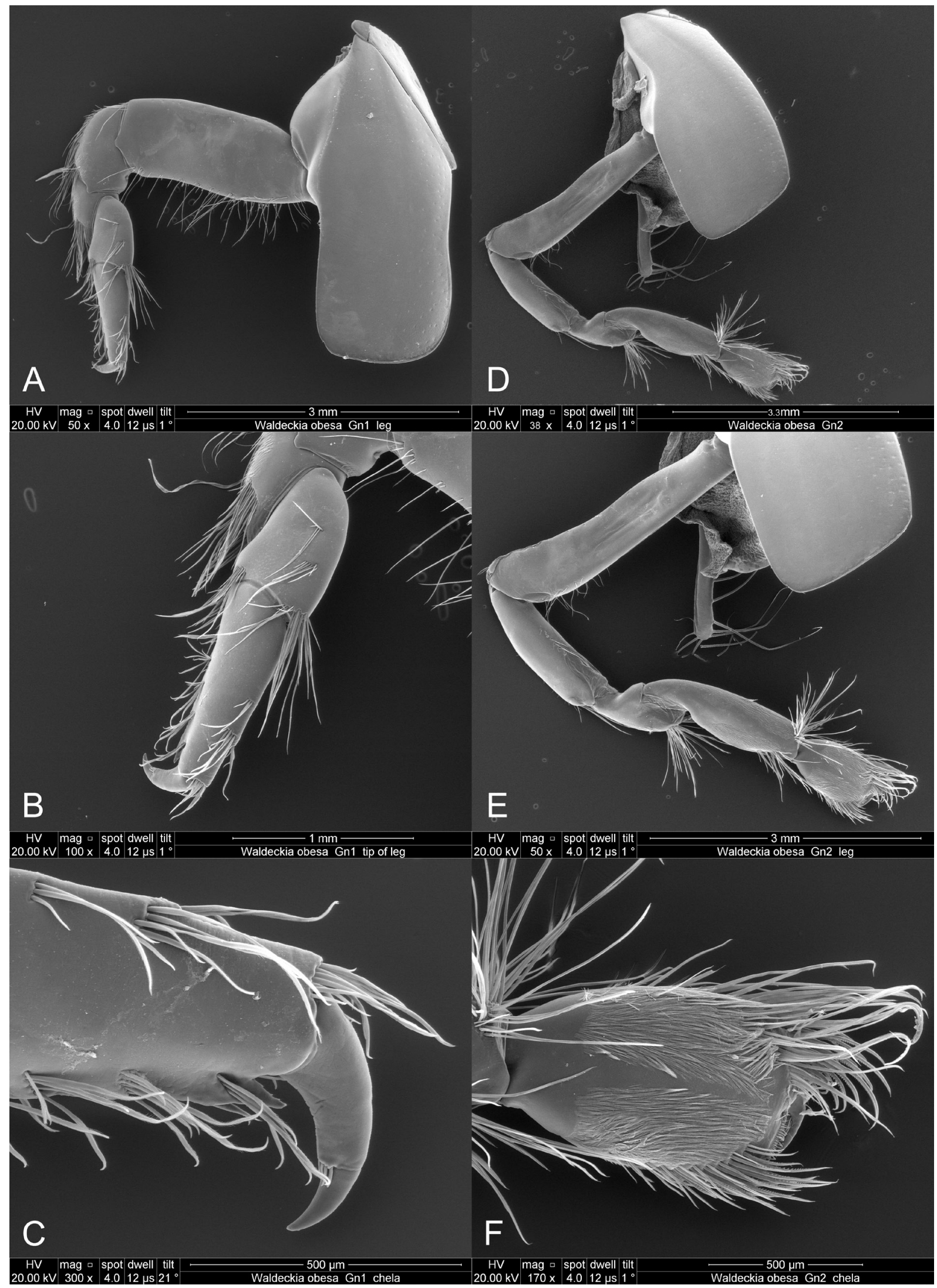

Fig. 18 - Charcotia obesa (Chevreux, 1906), mature female, REVOLTA II, stn REVO_048-REVO_220 (MNHN-IU-2016-3834, DNA extraction W14). A. Right Gn1. B. Distal half of right Gn1. C. Chela of right Gn1. D. Right Gn2. E. Right Gn2 (leg). F. Chela of right Gn2. 
minutely subchelate, propodus rounded, 1.6 times as long as wide, profusely setose, posterior corner of palm weakly not projecting beyond dactylus; dactylus fairly short, transverse.

PEREIOPOD 3 (Fig. 19A). Coxa large, about as long as coxa 4, subrectangular, with anterior margin convex and posterior margin concave; leg neither especially stout nor especially slender; basis hairless or nearly so, ischium, merus and carpus with many long setae posteriorly; posterior border of propodus with nine short spines or pairs of short spines; dactylus normally developed, curved, with long unguis.

Pereiopod 4 (Fig. 19C-C'). Coxa as deep as wide, posteroventral lobe narrow and extremely long, anterior border distinctly convex connecting to ventral border by well-defined obtuse (nearly right) angle, ventral border straight on anterior 0.7 , strongly curving just behind anterior 0.7 , posteriorly nearly straight and pointing upwards; posteroventral lobe very long, as long as the more anterior part of the coxa, tip of posteroventral lobe bluntly triangular; leg neither especially stout nor especially slender; basis hairless or nearly so, ischium, merus and carpus with many long setae posteriorly; merus and carpus with anterodistal tuft of setae; propodus 3.7 times as long as wide, posterior border of propodus with nine pairs of short spines; dactylus normally developed, robust, curved, with long unguis, 0.46 times as long as propodus.

PEREIOPOD 5 (Fig. 19D). Coxa encased in the 270-degree angle formed by the posterior border and the posteroventral lobe of coxa 4, very slightly deeper than wide, subquadrate (borders slightly diverging in a ventral direction), anterior border slightly convex and posterior border straight on most of its length, anteroventral corner broadly rounded, posteroventral corner forming a well-defined obtuse (nearly right) angle; basis bluntly rectangular, slightly longer than broad with anterior border forming a strong regular curve on its distal 0.6 ; merus broad, with posterior border setose and posterodistally terminated by a small spine; propodus 4.1 times as long as wide, anterior border with seven pairs of short spines; dactylus normally developed, robust, curved, with long unguis, 0.56 times as long as propodus.

PEREIOPOD 6 (Fig. 19E-F). Coxa rectangular, anterior border 1.4 times as deep as wide, 1.4 times as long as basis, posterior border nearly straight (proximally weakly convex); basis 1.1 times as long as wide, with anterior border convex and posterior border proximally nearly straight and distally convex, anterior and posterior border not converging in distal direction, posterodistal border produced into a very broad, well-developed rounded lobe; merus broad, posterior border with setae and distal short spine; propodus 5.4 times as long as wide, anterior border with six pairs of short spines; dactylus normally developed, robust, curved, 0.4 times as long as propodus.

PEREIOPOD 7 (Fig. 19G-H). Coxa forming an irregular quadrilateral (nearly kite-shaped) with posteroventral corner round-tipped, slightly longer than broad, 0.8 times as long as basis; basis 1.1 times as long as broad, with 13 very short spines or groups of spines anteriorly, about 10 very weak crenellations posteriorly, anterior border weakly convex on proximal 0.25 , straight on distal 0.75 , posterodistal border weakly but distinctly convex, projecting into a low distal lobe, posterior border convex, junction between posterodistal and posterior border forming a curve with no real angular discontinuity; merus fairly broad, posterior border with short spines; propodus 4.7 times as long as broad, anterior border with seven pairs of short spines; dactylus normally developed, robust, curved, with long unguis, 0.49 times as long as propodus.

PLEONITE 1 (Fig. 20A). Epimeron anteroventral corner produced into a rounded projection pointing forward; ventral and posterior borders forming a curve.

PLEONITE 2 (Fig. 20A). Epimeron anteroventral corner rounded, ventral border straight, posteroventral corner forming a sharp right angle terminated by a small triangular tooth; posterior margin sinuate (upper part convex, lower part straight). 


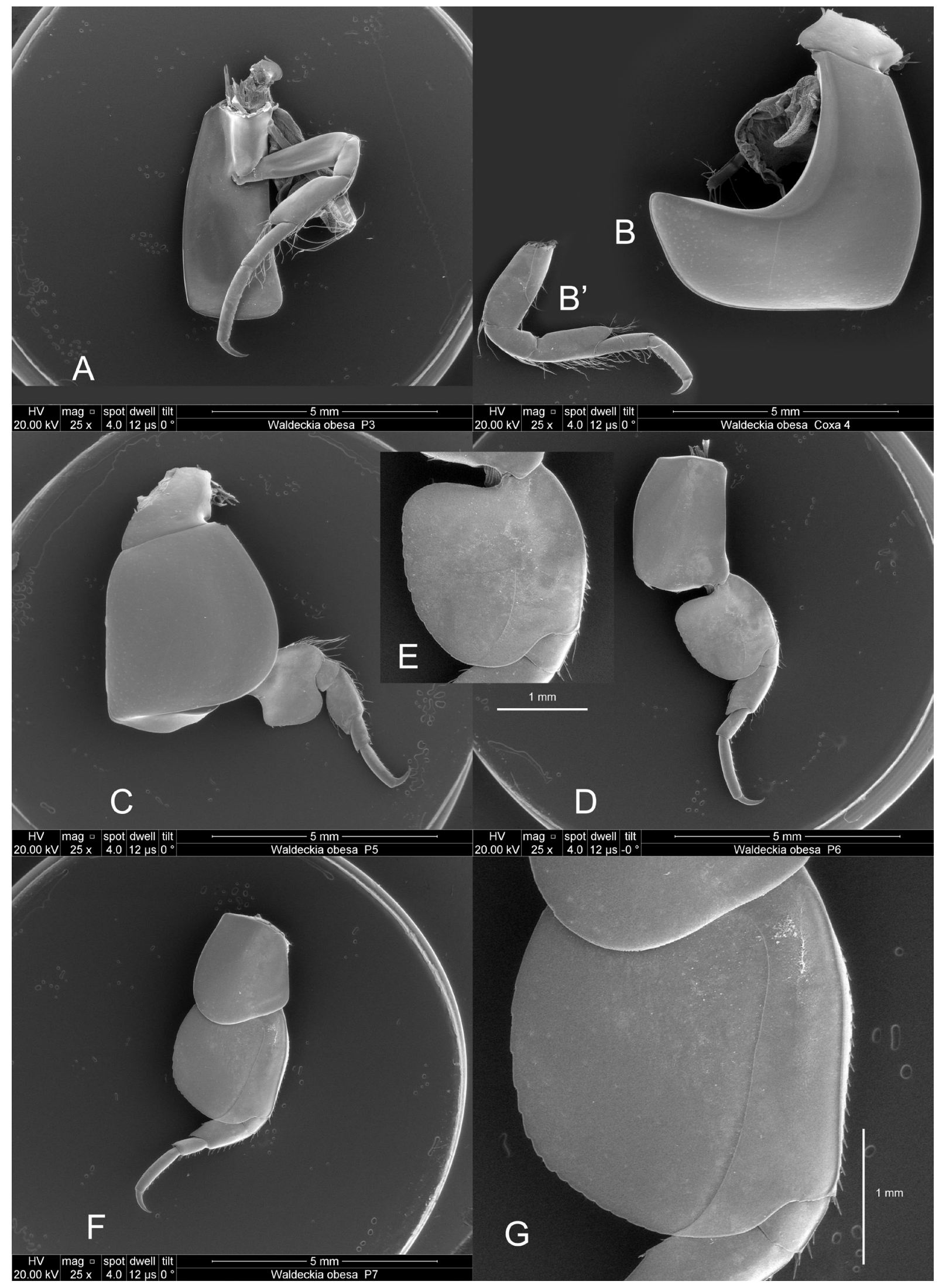

Fig. 19 - Charcotia obesa (Chevreux, 1906), mature female, REVOLTA II, stn REVO_048-REVO_220 (MNHN-IU-2016-3834, DNA extraction W14). A. Right P3. B. Right P4 (coxa). B' '. Right P4 (1eg). C. Right P5. D. Right P6. E. Basis of right P6. F. Right P7. G. Basis of right P7. 


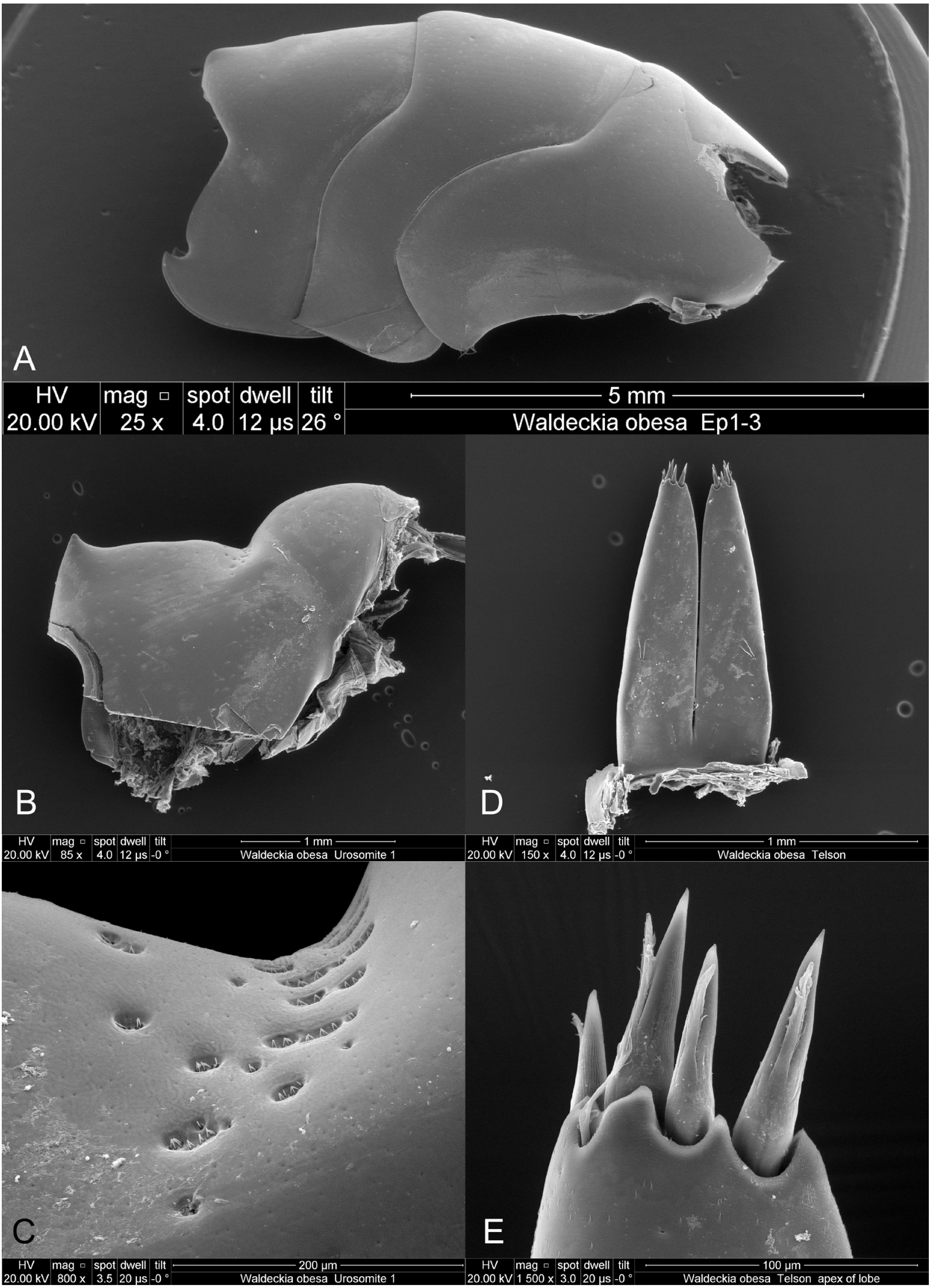

Fig. 20 - Charcotia obesa (Chevreux, 1906), mature female, REVOLTA II, stn REVO_048-REVO_220 (MNHN-IU-2016-3834, DNA extraction W14). A. Pleonites 1-3. B. Urosomite 1. C. Details of urosomite 1 showing unispathal pits. D. Telson. E. Tip of right lobe of telson. 
PLEONITE 3 (Figs 15D, 20A). Epimeron anteroventral corner rounded, ventral border weakly convex, posteroventral corner forming a large and sharp tooth; posterior margins slightly convex; posterodorsal tip of pleonite forming a blunt right angle.

Urosomite 1 (Figs 15D, 20B-C). Anteriorly with rounded elevation, followed by a low and nearly straight carina, terminating into a small triangular tooth pointing upwards. Proximal part of carina with unispaths not disposed in longitudinal grooves.

UROPOD 1 (Fig. 21A). Peduncle 1.2 times as long as inner ramus, with only one dorsolateral (tiny) spine (which is situated in distal position), and nine long and slender dorsomedial spines (of which eight are situated on proximal 0.4 and the last one in distal position); outer ramus 1.05 times as long as inner ramus, with about four small dorsolateral spines and no dorsomedial spines; inner ramus with seven small dorsolateral spines and six small dorsomedial spines.

UROPOD 2 (Fig. 21B). Peduncle 0.9 times as long as inner ramus, with 9 dorsolateral spines of size increasing towards tip, with about 10 regularly spaced dorsomedial setae followed by long distomedial spine; outer ramus 0.97 times as long as inner ramus, with 10 well developed dorsolateral spines and no dorsomedial spines; inner ramus with six well-developed dorsolateral spines and 6 well-developed dorsomedial spines.

UROPOD 3 (Figs 21B-C, 22). Peduncle ordinary, about 0.70 times as long as outer ramus; outer ramus article one with 6 or 7 lateral spines or pairs of lateral spines, 21 medial long plumose setae, article two 0.24 times as long as article one; inner ramus reaching base of article two of outer ramus; with 4 lateral spines and 4 long lateral plumose setae, with about 20 long medial plumose setae.

TELSON (Fig. 20D-E). Elongate, cleft 0.85 of length, each lobe with four apical spines, without dorsolateral spines.

\section{Colour pattern (Fig. 5B)}

Uniformly yellowish brown to bright yellow.

\section{Measurements}

The body length of one of the largest specimens examined was $33 \mathrm{~mm}$. Both sexes reach similar sizes.

\section{Taxonomic decisions}

Chevreux (1906a) recorded two syntype specimens, which are preserved in the Muséum national d'Histoire naturelle, Paris (they were not examined by us):

-1 ovigerous female, $17 \mathrm{~mm}$, Biscoe Bay, Anvers Island, stn 875, lat. S. 6450" [presumably $64^{\circ} 50^{\prime} \mathrm{S}$ ], dredge, 110 m, 11 Feb. 1905 (MNHN, Am2623).

- 1 specimen, Booth-Wandel Island, from the stomach of a chinstrap penguin Pygoscelis antarcticus (Forster, 1781), 4 Dec. 1904 (MNHN, Am 1068).

The female from Biscoe Bay was illustrated by Chevreux (1906a, b). There is a perfect concordance between these illustrations by Chevreux and the specimens identified herein as $C$. obesa. Therefore, we designate Chevreux's female from Biscoe Bay as the lectotype of Charcotia obesa. The specimen from Ile Booth-Wandel becomes a paralectotype. Since it comes from the stomach of a penguin, it probably comes from shallow-water and therefore it is very probably also a C. obesa.

\section{Distribution}

East of the Antarctic Peninsula (Chevreux, 1906a, 1906b; Thurston, 1974), South Shetland Islands, northwest of the Antarctic Peninsula, Enderby Land, Adélie Coast (present material). New and reliable 


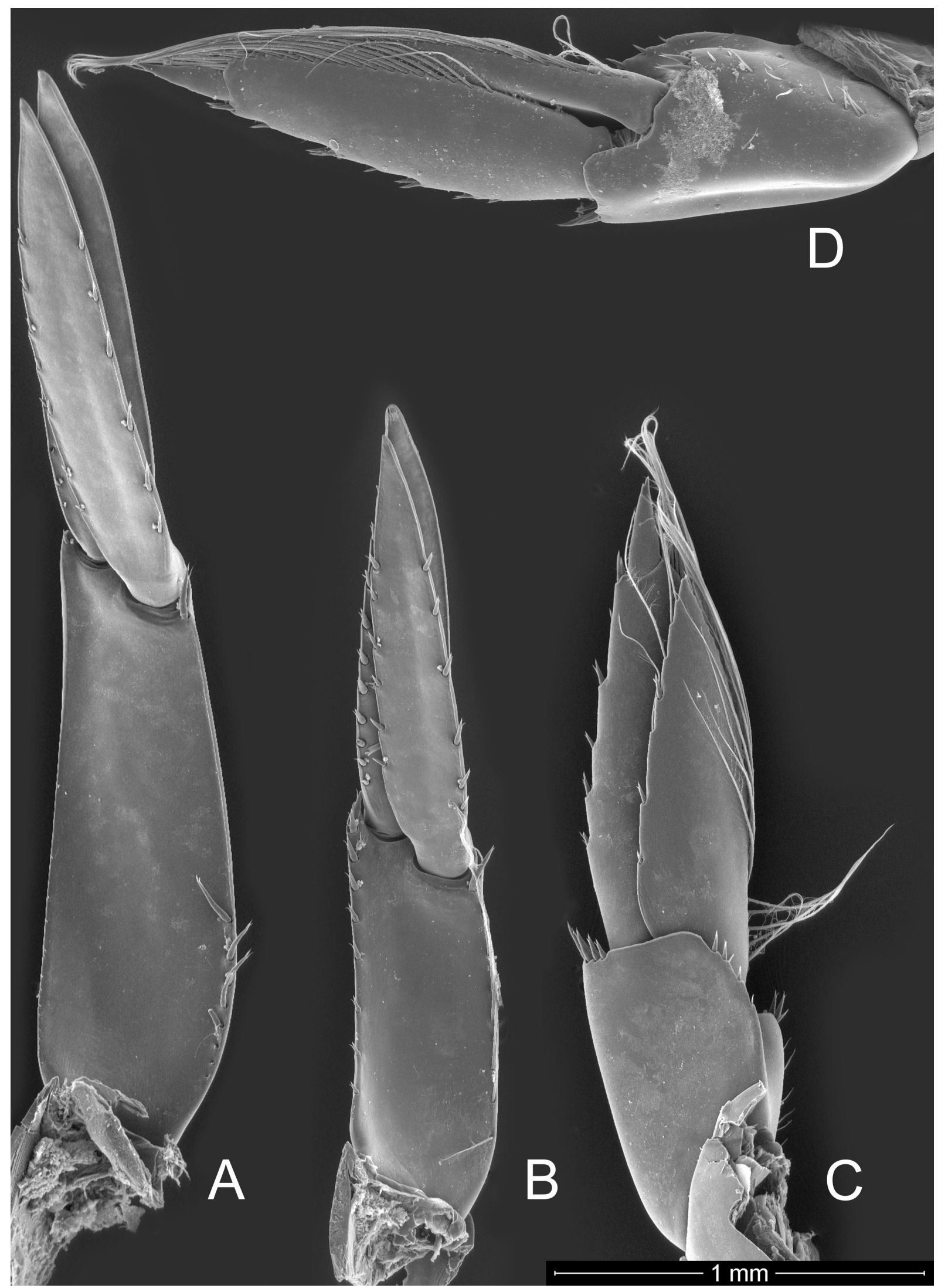

Fig. 21 - Charcotia obesa (Chevreux, 1906), mature female, REVOLTA II, stn REVO_048-REVO_220 (MNHN-IU-2016-3834, DNA extraction W14). A. Right U1 (dorsal view). B. Right Ü2 (dorsal view). C. Right U3 (dorsal view). D. Left U3 (ventral view). 


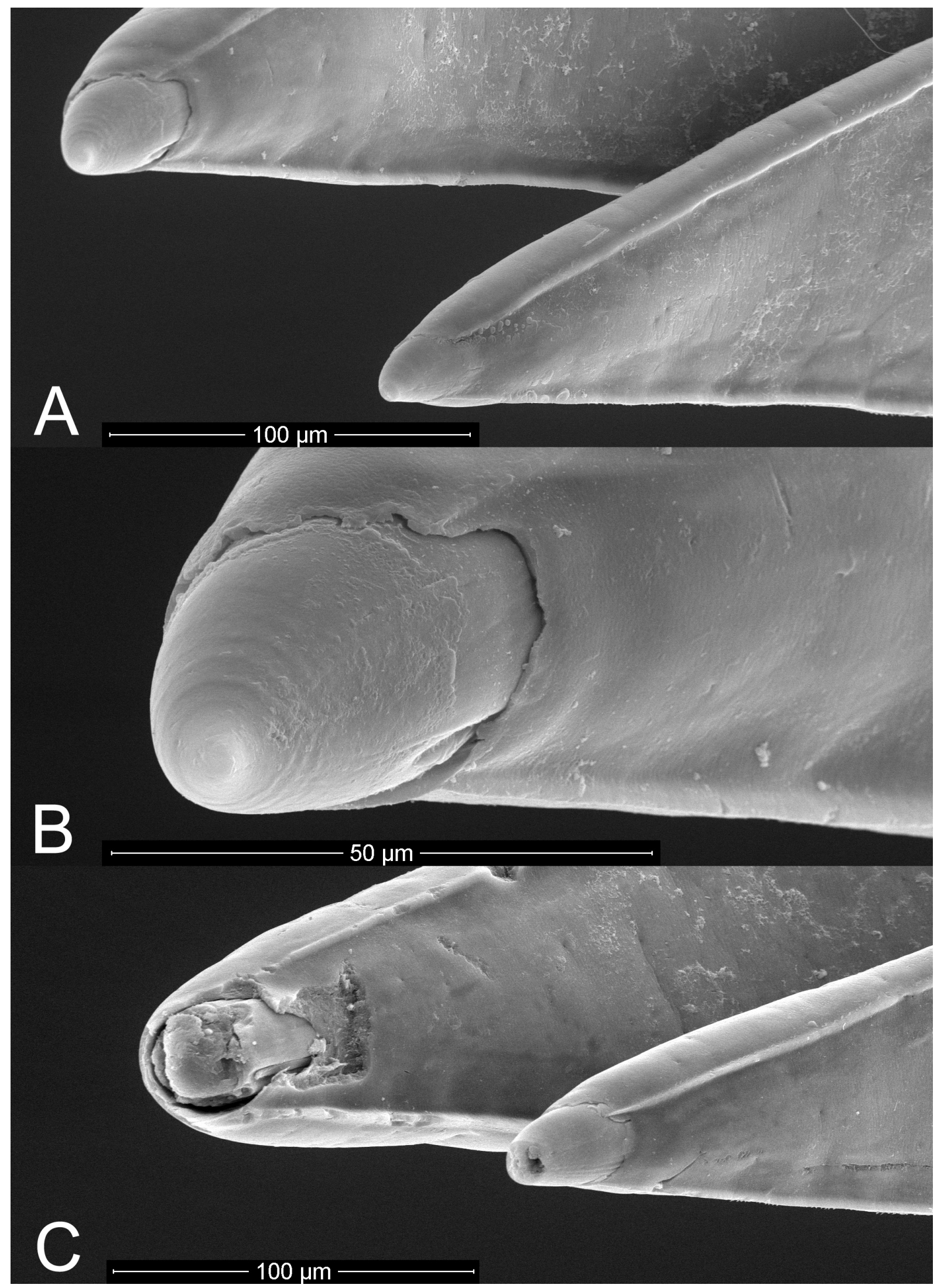

Fig. 22 - Charcotia obesa (Chevreux, 1906), mature female, REVOLTA II, stn REVO_048-REVO_220 (MNHN-IU-2016-3834, DNA extraction W14). A. Tip of right U1. B. Tip of inner ramus of right U1. C. Tip of right $\mathrm{U} 2$. 
literature records are mapped on Figure 2. There are many other records of Charcotia obesa in literature (DE BROYER et al., 2007). Some are clearly based on C. obesa or C. amundseni sp. nov., but in many cases, the species identity could not be confirmed. In the same way as Charcotia amundseni sp. nov., C. obesa presumably has a circum-Antarctic distribution. Intertidal (THURSTON, 1974) to $298 \mathrm{~m}$ (present material).

\section{Biology}

In Charcotia obesa, the second antenna dramatically increases in length in males (reaching about $80 \%$ of body length) when they reach their sexual maturity. The huge numbers of $C$. obesa collected with baited traps indicate that it is a scavenger (CHAPELLE, 1991). According to ARNAUD (1970), on Adélie Coast, the number of specimens caught in traps put in shallow water is much higher in winter than in summer. This has not been reported elsewhere. Charcotia obesa is sometimes parasitized by acanthocephalans (ZDZITOWIECKI, 2001; ZDZITOWIECKI \& PRESLER, 2001). According to CHAPELle (1991), females (and probably males) are iteroparous, females lay one egg clutch per year (maximum number of eggs per clutch $=25$ ). The abundance of hatchlings peaks in October (CHAPELLE, 1991).

\section{Remarks}

Orchomene arnaudi Bellan-Santini, 1972 and Waldeckia robusta Ren in Ren \& Huang, 1991 have been described after juvenile specimens. DE BROYER et al. (2007) and LOWRY \& KILGALLEN (2014) considered them as junior synonyms of Charcotia obesa Chevreux, 1906. Their original descriptions indeed agree with young $C$. obesa and not with young $C$. amundseni sp. nov., which have a stronger urosomal process and a smaller tooth on epimeron 3.

\section{Discussion}

\section{Attempt to identify specimens of Charcotia to species level in former biological studies}

Antarctic species of Charcotia are sturdy amphipods easily obtained in large numbers (STORCH et al., 1999) and reasonably easy to keep alive for extended periods (KLAGES, 1991). As such, they are excellent experimental models and have been investigated in a wide range of biological studies - under the name 'Waldeckia obesa' (for a review see DE BROYER et al., 2007). The present paper demonstrates that two common species were confused under the name 'Waldeckia obesa', which questions the reliability of these studies. We have examined the most important biological and ecological papers mentioning 'Waldeckia obesa', and have tried, as far as possible, to determine which species was/were (presumably) involved. A literature review, which is not an exhaustive list, is given below. Papers already cited in the systematic synonymy are not cited again.

\section{Papers (presumably) concerning Charcotia amundseni sp. nov.}

The important paper of DAUBY et al. (2001b) on the trophic biology of amphipods from the Weddell Sea was at least partly based on $C$. amundseni sp. nov., because some of its experimental material was preserved and examined by us. Specimens from the cruises ANT-VII/4 (EPOS Leg 3), ANT-XIII/3 (EASIZ I) and ANT-XV/3 (EASIZ II) examined by us were all C. amundseni sp. nov. Material from the same expeditions used in other studies by STORCH et al. (1999), Bluhm (2001), Bluhm et al. (2001a, b), DAUBy et al. (2001a), GRAEVe et al. (2001), De BROYer et al. (2001, 2004) and NYSSEN et al. (2001, 2002), presumably also belong to C. amundseni sp. nov., based on their origin. Moreover, BLUHM et al. (2001a) indicated that their material was collected between 400 and $800 \mathrm{~m}$, i.e., at depths where only C. amundseni sp. nov. was recorded.

\section{Papers (presumably) concerning Charcotia obesa}

We have examined a large number of Charcotia from Admiralty Bay collected between 50 and $200 \mathrm{~m}$ and they have all proven to be C. obesa. So, it is likely that this is the only species of Charcotia present 
there, at least at shallow and medium depths. Hence, the following biological studies are probably exclusively based on C. obesa, as they are focused on specimens from Admiralty Bay collected at depths shallower than 200 m: Presler (1986), Chapelle (1991), ChAPElle \& PeCK (1995), ChAPELle et al. (1994), GOMES et al. (1993, 1995), RAKUSA-SUSZCZEWSKI \& LACH (1991), JAŻDŻEWSKI \& KONOPACKA (1999), ZdZITOWIECKI (2001), ZDZITOWIECKI \& PRESLER (2001), JANECKI \& RAKUSA-SUSZCZEWSKI (2005), JAŻDŻEWSKA (2009), PECK et al. (2009) and RAKUSA-SUSZCZEWSKI et al. (2010). The material studied by ARNAUD (1970) was obviously based on C. obesa, because it was collected in shallow-water near the Dumont d'Urville Station, off Adélie Coast and all the shallow-water specimens from the same area examined by us were C. obesa.

\section{Papers involving a mixture of Charcotia obesa and C. amundseni}

The largest part of the material studied by DE BROYER (1983) was re-examined. It included a mixture of the two species, with a predominance of $C$. amundseni sp. nov.

\section{Papers involving species of Charcotia, which cannot be identified}

BELLAN-SANTINI (1972) gave an extensive list of specimens collected off Adélie Coast, from a wide range of depths $(15-240 \mathrm{~m})$ and provided colour notes. Considering what we found in our material collected at similar depths in the same area, it is likely that her material included both Charcotia obesa and $C$. amundseni sp. nov., with only C. obesa in the shallowest samples. The identity of the species used by COLEMAN (1991, 1992a, b) for his morphological and morphofunctional studies on Charcotia cannot be inferred from the information provided. The identity of 'Waldeckia cf. obesa' and the 'Waldeckia sp.' in TAKEUCHI et al. (2002) is also unclear. Their material was collected at 171 and $353 \mathrm{~m}$. At such depths, C. amundseni sp. nov. is usually prevalent but the occurrence of $C$. obesa at the shallowest station remains possible. The cautious identifications of the Japanese authors suggest that they perceived that there was a taxonomic problem with Antarctic species of Charcotia. This supports the idea that their material was $C$. amundseni sp. nov. or a mixture of the two Antarctic Charcotia species. It cannot be established which species of Charcotia was/were involved in the study of the biomarkers of 'Waldeckia obesa' by NYSSEN et al. (2005). These authors used material collected by various sampling gears during the cruises ANT-XIX/3\&4 (ANDEEP I\&II) in the north of the South Shetland Islands. Both species can be expected in the depth range sampled during these cruises ranging from 78 to $5000 \mathrm{~m}$ (FÜTTERER et al. 2003 ) and no material from that cruise could be examined by us. The study on trace metals by KeIL et al. (2008) does not provide the required information for determining the species of Charcotia involved. Unlike most papers focusing on Admiralty Bay (which only treated samples collected above $200 \mathrm{~m}$ ), the studies of JAŻDŻEWSKA (2011) and JAŻDŻEWSKA \& SICIŃSKI (2017) listed Charcotia specimens from the deeper part of the bay (below $200 \mathrm{~m}$ ). As such, it cannot be ruled out that it included some C. amundseni sp. nov. in the deepest stations (in addition to C. obesa).

\section{Trophic ecology}

Charcotia amundseni sp. nov. and C. obesa belong to the so-called Antarctic scavenger guild, which mostly consists of lysanassoid amphipods and cirolanid isopods (DE BROYER et al., 2004). The biology of the different lysianassoids of this guild is different. Species of Charcotia are "obese" and heavily calcified and seem to be strictly benthic. In contrast, the common and much less calcified Pseudorchomene plebs (Hurley, 1965) and P. rossi (Walker, 1903) are benthopelagic, as they are commonly collected in midwater trawls (DAUBY et al., 2001b; D'UdEKEM D'ACOZ \& VeRHEYe, 2013). Charcotia spp. are endowed with an enlarged stomach (COLEMAN, 1991, 1992a), which is not uncommon in lysianassoids living in extreme environments (DAHL, 1979). Charcotia spp. are able to ingest so much food that it requires several weeks for digestion (STORCH et al., 1999). In contrast, another important member of the necrophagous guild, Pseudorchomene plebs, does not retain food in its stomach for more than 8 days (RAKUSA-SUSZCZEWSKI, 1982). Pseudorchomene plebs has been reported to be able to survive without food for over one month. This is not as long as the periods recorded for Charcotia spp., which have been 
reported to survive starvation for up to 18 months (COLEMAN, 1991). At the bottom of old jars containing hundreds of Charcotia obesa specimens, which were never processed after fixation, we found a thick layer of a white and viscous substance, which presumably consisted of lipids released by the specimens of Charcotia. This suggests that these amphipods are able to store huge amounts of lipid reserves, presumably in much higher quantity than the less bulky and more active P. plebs. In Charcotia spp., the fatty acid composition of these lipids is fairly similar to that of other necrophagous amphipods such as P. plebs (with a dominance of 18:1(n-9) fatty acids) (NYSSEN et al., 2005). However, the proportion of the different fatty acids found in Charcotia spp. is unique. This suggests some specificity in their trophic niche such as preference for a specific category of dead organisms/tissues and/or presence/absence of specific dietary complements (in addition to carrion). This hypothesis is supported by different lines of evidence. For example, RAKUSA-SUSZCZEWSKI et al. (2010) observed that Pseudorchomene plebs and Charcotia obesa have different reactions when exposed to the same amino acids in aquariums. They stated: "...we suppose these species consume different food, and this may decrease interspecific competition." Furthermore, DAUBY et al. (2001b) reported a wider range of food items in the stomach of P. plebs (crustacean remains and diatoms in additions to pieces of carrion) than in C. amundseni (hardly recognizable and variously coloured organic material, wherein fragments of striated muscles could be distinguished), suggesting a less opportunistic trophic niche in Charcotia spp. than in P. plebs. These putatively different feeding habits are reflected in the morphology of gnathopod 1, which plays an important role in the processing of food items. In Charcotia spp., gnathopod 1 is robust and nearly pediform, while it is robust and subchelate in Pseudorchomene plebs and P. rossi, slender and subpediform in P. coatsi (Chilton, 1912), and extremely slender and subpediform in P. lophorachis d'Udekem d'Acoz \& Havermans, 2012 (D’UDEKEM D'ACOZ \& HAVERMANS, 2012).

\section{Digestibility of Charcotia for humans and other vertebrates}

Cyril Gallut (pers. comm.) witnessed that Charcotia obesa is unfit for human consumption, as the ingestion of entire cooked specimens by his colleagues resulted in severe gastrointestinal disturbances. The nature of this toxicity for humans is unclear. Wax esters from deepsea fishes have been reported to have intense keriorrhoetic effects on humans (BARLING \& FOONG, 2015) and this kind of complex lipids has been reported to be abundant in some crustaceans (LEE et al., 1970). However, GRAEVE et al. (2001) and NYSSEN et al. (2005) indicated that wax esters are not the prevalent form of complex lipids occurring in Charcotia. According to GRAEVE et al. (2001), triacylglycerols and to a lesser extent phospholipids predominate in Charcotia. GRAEVE et al. (2001) and NYSSEN et al. (2005) indicated that 18:1(n-9) fatty acids (i.e., oleic acid) accounted for $>44 \%$ of total fatty acids of Charcotia spp. As far as we know, oleic acid combined in triacylglycerols or phospholipids cannot be the cause of gastrointestinal disturbances. On the other hand, high fluoride concentrations have been reported in various Antarctic crustaceans (including amphipods), especially in their exoskeleton (SANDS et al., 1998). They can reach levels potentially toxic to humans (ZHANG et al., 2013b) and intestinal disturbances are one of the adverse effects of high levels of fluoride ingestion (KANDUTY et al., 2016). It cannot be ruled out that Charcotia spp. accumulate fluoride to toxic levels in their thick chitinous exoskeleton or perhaps in their body fluids. Finally, an alternative causal factor of the Charcotia toxicity might be the carrion stored in their enlarged stomaches. Whatever the explanation, the non-digestibility of Antarctic species of Charcotia is not universal in the animal kingdom, as they have been reported to be part of the diet of penguins (e.g., OFFREDO \& RIDOUX, 1986) and fishes (e.g., LINKOWSKI et al., 1983).

\section{Bathymetric preferences of Charcotia amundseni sp. nov. and C. obesa}

The two Antarctic Charcotia species are morphologically comparable and seem to have a similar trophic ecology. However, the two species are infrequently found together. There is a strong correlation between depth and their presence/absence/abundance. Charcotia obesa was found between 0-300 m, with its abundance usually decreasing below $150 \mathrm{~m}$. In contrast, $C$. amundseni sp. nov. was mostly recorded between 140-1200 m, with a single record from $9 \mathrm{~m}$ depth (NAGATA, 1986, as Waldeckia obesa). The 
isolated records of the two species of Charcotia outside their usual bathymetric ranges and the different relative abundance of the two species at the same depth in different localities suggest that other, as yet to be established factors might also influence the presence of these species.

\section{Distribution patchiness}

Specimens of Charcotia are obtained here and there with trawls, usually (but not always) in low numbers (C. d'Udekem d'Acoz \& H. Robert, pers. obs.). However, as they are scavengers, baited traps are by far the most efficient method for collecting them. The species composition of the amphipods in baited traps used in Antarctic seas is variable, but at depths shallower than $800 \mathrm{~m}$, Pseudorchomene plebs is always abundant and often dominant (C. d'Udekem d'Acoz \& H. Robert, pers. obs.). The literature suggests that specimens of Charcotia are caught in traps nearly everywhere at depths less than $100 \mathrm{~m}$. On the other hand, at greater depths, traps catch specimens of Charcotia only locally. For example, no specimens were collected with traps during the cruises ANT-XXIII/8 and ANT-XXIX/3: below $100 \mathrm{~m}$ in the South Shetland/Antarctic Peninsula area (D'UDEKEM D'ACOZ \& ROBERT, 2008; D'UDEKEM D'ACOZ \& VERHEYE, 2013). In contrast, during ANT-XV/3, thousands of specimens were collected with traps at similar depths in the East Weddell Sea (STORCH et al., 1999). Such differences might reflect the local availability of food items, bearing in mind that Charcotia is heavier, less mobile and apparently trophically less opportunistic than the ubiquist $P$. plebs. However, this statement remains highly speculative because no hypothetical food items present in one area and absent in the other can be suggested. In contrast, the extreme abundance of Charcotia obesa in the shallow and medium depths of Admiralty Bay could partly be explained by its large rookeries of penguins and other seabirds and also its colonies of seals (e.g., SIERAKOWSKI, 1991), which undoubtedly provide the Charcotia obesa population with a regular supply of carcasses and possibly also droppings.

\section{Iteroparity and life cycle}

Charcotia obesa is presumably iteroparous. Indeed, the female dissected for the SEM study had fully developed setigerous oostegites, which suggests an already hatched brood in its current intermoult. At the same time, ovaries were full of eggs indicating that a new brood was in preparation, presumably for the next intermoult. CHAPELLE (1991: 84) made similar observations. Moreover, in analysing the population structure at Admiralty Bay, CHAPELLE (1991) concluded that females would reach maturity after nine or 10 moults and be able to perform up to three additional moults. The same author considered that male $C$. obesa would reach maturity after 10 moults and would possibly moult one more time after the puberty moult, where antenna 2 dramatically increases in length. On the basis of indirect evidences, it was suggested that $C$. amundseni sp. nov. would also be iteroparous (BLuHM et al., 2001a, as 'Waldeckia obesa'). At least in the case of C. obesa, the number of eggs per clutch is low, with a maximum of 25 eggs (CHAPELLE, 1991). According to BLUHM et al. (2001a), species of Charcotia are slow-growing and long-living amphipods with an estimated maximum age of up to eight years for female $C$. amundseni sp. nov. (under the name 'Waldeckia obesa').

\section{Commensal ciliate protozoans on the dactylus of gnathopod 2 in Charcotia spp.}

The occurrence of epibiontic protozoans is not uncommon in amphipods (FERNANDEZ-LEBORANS et al., 2016). In both species of Charcotia, sagittiform protozoans were observed on the dactylus of gnathopod 2 (Fig. 10H). According to Gregorio Fernandez-Leborans (pers. com.), they are probably chonotrich ciliates. Gnathopods are used by amphipods for removing and handling food items and it can be assumed that these epibiontic protozoans feed on remaining food scraps.

\section{The spatheform organ: an overlooked character in amphipod taxonomy?}

The spatheform organ is a system of unclear function, possibly a ballasting organ. It consists of an assemblage of tiny erect projections (unispathes), often inserted into pits, disposed in regular patterns 
(often in files) across the whole body of amphipods and isopods, and occurring at especially high densities on the urosome (KAÏM-MALKA, 2010). By using scanning electron microscopy, our study shows that also Charcotia possesses this organ. Interestingly, the disposition of the unispathes on urosomite 1 is different in the two Charcotia species (compare Figures 12 and 20). So far, the spatheform organ has not been used in the descriptive taxonomy of amphipods, but it might prove to be an important character for separating very similar species on a morphological basis.

\section{Pairs of similar Antarctic amphipod species with different bathymetric distributions: probably a trend}

Our knowledge on the Antarctic amphipods is still very incomplete and taxonomic studies are often hampered by older descriptions of poor quality. In the past, many species were erroneously considered as circum-Antarctic (DE BROYER et al., 2007), while they actually consist of a mixture of very similar species with a more limited distribution (e.g., VERHEYE et al., 2016; D'UDEKEM D'ACOZ \& VERHEYE, 2017). However, this is not the case for the two Antarctic Charcotia species, which are shown herein to be truly circum-Antarctic.

There are also reports of similar Antarctic amphipod species with different bathymetric distributions, which have been or might have been the object of past confusions. D'UDEKEM D'ACOZ (2009) described Liljeborgia bathysciarum d'Udekem d'Acoz, 2009 from the Antarctic continental slope, which is extremely similar to L. georgiana Schellenberg, 1931 from the continental shelf. D'UDEKEM D'ACOZ \& VERHEYE (2017) report that species previously grouped under the names Epimeria similis Chevreux, 1912 and E. georgiana Schellenberg, 1931 consisted of several species, some usually found at greater depths than others. Close to the tip of the Antarctic Peninsula, D'Udekem D'ACOZ \& VerHeYe (2013) found two very different 'colour morphs' in Paraceradocus gibber Andres, 1984 s.l., with different bathymetric distributions, which they suspected to be different species. Similar cases confirmed by molecular data were observed for Eusirus perdentatus Chevreux, 1912 and Eusirus giganteus Andres, Lörz \& Brandt, 2002 (Verheye, 2010; D'UdeKEM D'ACOZ \& VerheYe, 2013). The two Charcotia species recorded here fit into this pattern, with one species (C. obesa) being found between $0-300 \mathrm{~m}$ (mostly between 0-150 m) and the other species (C. amundseni) occurring between 7-1200 m (mostly below $150 \mathrm{~m}$ ). It is likely that more species pairs with different bathymetric optima will be uncovered in the Antarctic Seas.

\section{Conclusions}

Charcotia obesa s.l. was split into two species (C. amundseni sp. nov. and C. obesa s.s.) based on molecular, morphological and ecological data and observations. The biology of the two Charcotia species appears similar but it is not identical. C. obesa is a predominantly shallow-water species, while $C$. amundseni sp. nov. prefers bathyal depths. Physiological differences linked to their different bathymetric preferences and other unique biological traits presumably exist. The past confusion between the two species somewhat questions the validity of former studies, although in most cases, it was possible to guess which species was involved.

The discovery that two common similar species were previously confused under the name 'Waldeckia obesa' partly invalidates previous studies using this 'composite taxon' as model for biological studies. This demonstrates yet again that the taxonomic knowledge of Antarctic amphipods has not reached a level effectively operational for ecological and biological studies. It also indicates the need and motivation for establishing a strategy aimed at filling the gaps in our systematic knowledge, with the relevant required funding.

\section{Acknowledgements}

Cyril Gallut (Pierre et Marie Curie Université, Paris) and Marc Eléaume (Muséum National d'Histoire Naturelle, Paris) invited the first author to the Antarctic Biodiversity Workshop in Concarneau, 24 Oct. - 
2 Nov. 2016, where specimens used in the genetic study were found. Catherine Ozouf-Costaz (Muséum national d'Histoire naturelle, Paris) proposed, as a hypothesis, that the toxicity of Charcotia obesa to humans might be the consequence of fluoride accumulation (information communicated to us by Cyril Gallut). The research programme led by Guillaume Lecointre, REVOLTA 1124 supported by the Institut polaire français Paul Émile Victor (IPEV) and the Muséum national d'Histoire naturelle (MNHN) (via Laure Corbari) are acknowledged for giving us access to biological material of invaluable interest. The CAML-CEAMARC cruise of RSV Aurora Australis (IPY project n53) was supported by the Australian Antarctic Division, the Japanese Science Foundation and the Institut polaire français Paul Émile Victor (IPEV) (programme ICOTA). The authors wish to thank Huw Griffiths and Katrin Linse (British Antarctic Survey) who made the specimens collected by the RRS James Clark Ross available to us. Anton Van de Putte (RBINS) created the map. This publication is registered as CAML (Census of Antarctic Marine Life) publication No. 32 and ANDEEP contribution No. 216. This is contribution no. 018 to the vERSO project and contribution no. 002 of the rECTO project, funded by the Belgian Science Policy Office (BELSPO, contracts $n^{\circ} B R / 132 / A 1 / v E R S O$ and $\left.n^{\circ} B R / 154 / A 1 / R E C T O\right)$. SEM photographs were carried out by Julien Cillis (RBINS) and we thank him for his efforts to generate the best pictures possible. Gregorio Fernandez-Leborans (Universidad Complutense, Madrid) provided us with information on epibiont protozoans living on crustaceans. Martyn E.Y. Low (National University of Singapore) provided essential information for establishing the dates of publication of Charcotia Chevreux, 1906 and Charcotia Vayssière, 1906. Sammy De Grave (Oxford Natural History Museum) and Philippe Bouchet (MNHN) also provided pertinent advice for handling this "thorny" nomenclatural issue. Tasnim Patel (PhD student at RBINS) checked the English text.

\section{References}

Altschul S.F., Madden T.L., SchÄffer A.A., Zhang J., Zhang Z., Miller W. \& LipMAN D.J. (1997). Gapped BLAST and PSI-BLAST: a new generation of protein database search programs. Nucleic Acids Research 25 (17): 3389-3402.

ARNAUD P.M. (1970). Feeding and ecological significance of necrophagy among the benthic species of Antarctic coastal waters. In: Holdgate M.W. (ed.), Antarctic Ecology, vol. 1: 259-267. Academic Press, London.

ARNTZ W. \& GUTT J. (1997). The expedition ANTARKTIS XIII/3 (EASIZ I) of "Polarstern" to the eastern Weddell Sea in 1996. Berichte zur Polarforschung 249: 1-148.

ARNTZ W. \& GUTT J. (1999). The expedition ANTARKTIS XV/3 (EASIZ II) of RV "Polarstern" in 1998. Berichte zur Polarforschung 301: 1-229.

ARNTZ W., ERNST W. \& HEMPEL I. (1990). The expedition ANTARKTIS VII/4 (EPOS leg 3) and VII/5 of RV "Polarstern" in 1989. Berichte zur Polarforschung 68: 1-214.

BARLING P.M. \& FoONG Y.H. (2015). Oily fish, liquid wax esters and keriorrhoea - a review. International e-Journal of Science, Medicine \& Education 9 (1): 21-25.

BATHMAnN U. (2010). The expedition of the research vessel "Polarstern" to the Antarctic in 2007/2008 (ANT-XXIV/2). Berichte zur Polar- und Meeresforschung 604: 1-200.

Bellan-SANTINI D. (1972). Invertébrés marins des XIIème et XVème Expéditions Antarctiques Françaises en Terre Adélie. 10. Amphipodes Gammariens. Téthys, Suppl. 4: 157-238.

Bellan-SAntini D. \& Ledoyer M. (1974). Gammariens (Crustacea - Amphipoda) des îles Kerguelen et Crozet. Téthys 5 (4): 635-708.

Bellisio N. \& Tomo A. (1974). Biogeografía de la Península Antártica, archipiélagos y mares adyacentes. Buenos Aires : Servicio de Hidrografia Naval H-918: 1-222. 
BluHM B. (2001). Age determination in polar Crustacea using the autofluorescent pigment lipofuscin. Berichte zur Polarforschung und Meeresforschung 382: 1-127.

BluHM B.A., BREY T. \& KlAgeS M. (2001a). The autofluorescent age pigment lipofuscin: key to age, growth and productivity of the Antarctic amphipod Waldeckia obesa (Chevreux, 1905). Journal of Experimental Marine Biology and Ecology 258 (2): 215-235.

https://doi.org/10.1016/S0022-0981(01)00214-3

Bluhm B.A., Brey T., KLAges M. \& ARNTZ W.E. (2001b). Occurence of the autofluorescent pigment, lipofuchsin, in polar crustaceans and its potential as an age marker. Polar Biology 24 (9): 642-649. https://doi.org/10.1007/s003000100258

Bouchet P., Rocroi J.-P., Hausdorf B., Kaim A., Kano Y., Nützel A., Parkhaev P., Schrödl M. \& STRONG E.E. (2017). Revised classification, nomenclator and typification of gastropod families. Malacologia 61 (1-2): 1-526. https://doi.org/10.4002/040.061.0201

Chapelle G. (1991). Cycle de dévelopment et «saisonalité» de la reproduction de Waldeckia obesa, Chevreux, amphipode nécrophage antarctique. MSc thesis, Université Catholique de Louvain, Louvainla-Neuve.

Chapelle G. \& PeCK L.S. (1995). The influence of acclimation and substratum on the metabolism of the Antarctic amphipods Waldeckia obesa (Chevreux 1905) and Bovallia gigantea (Pfeffer 1888). Polar Biology 15 (3): 225-232. https://doi.org/10.1007/BF00239063

Chapelle G., PeCK L.S. \& Clarke A. (1994). Effects of feeding and starvation on the metabolic rate of the necrophagous Antarctic amphipod Waldeckia obesa (Chevreux, 1905). Journal of Experimental Marine Biology and Ecology 183 (1): 63-76. https://doi.org/10.1016/0022-0981(94)90157-0

Chevreux E. (1906a). Diagnoses d'amphipodes nouveaux provenant de l'expédition antarctique du Français. I. Lysianassidae. Bulletin de la Société Zoologique de France 30: 159-165.

Chevreux E. (1906b). Crustacés amphipodes. In: Expédition Antarctique Française (1903-1905) commandée par le Dr Jean CHARCOT. Sciences Naturelles: Documents Scientifiques: 1-100. Masson et Cie (eds), Paris. https://doi.org/10.5962/bhl.title.7063

Chilton C. (1912). The Amphipoda of the Scottish National Antarctic Expedition. Transactions of the Royal Society of Edinburgh 48 (3): 455-520, pls 1-2.

Chilton C. (1913). Revision of the Amphipoda from South Georgia in the Hamburg Museum. Mitteilungen aus dem Naturhistorischen Museum in Hamburg 30: 53-63.

Clement M., Posada D. \& CRAndall K. (2000). TCS: a computer program to estimate gene genealogies. Molecular Ecology 9 (10): 1657-1660. https://doi.org/10.1046/j.1365-294x.2000.01020.x

COLEMAN C.O. (1991). Comparative fore-gut morphology of Antarctic Amphipoda (Crustacea) adapted to different food sources. Hydrobiologia 223 (1): 1-9. https://doi.org/10.1007/BF00047623

COLEMAN C.O. (1992a). Foregut morphology of Amphipoda (Crustacea). An example of its relevance for systematics. Ophelia 36 (2): 135-150. https://doi.org/10.1080/00785326.1992.10430364

COLEMAN C.O. (1992b). The transverse apodeme bridge from the cephalothorax of Amphipoda (Crustacea) and its significance for systematics. Journal of Natural History 36 (1): 37-49. https://doi.org/10.1080/713833836

Coleman C.O. (2003). "Digital inking": How to make perfect line drawings on computers. Organisms, Diversity and Evolution, Electronic Supplement 14: 1-14.

COLEMAN C.O. (2009). Drawing setae the digital way. Zoosystematics and Evolution 85 (2): 305-310. https://doi.org/10.1002/zoos.200900008 
DAHL E. (1979). Deep-sea carrion feeding amphipods: Evolutionary patterns in niche adaptation. Oikos 33: $167-175$.

Darriba D., Taboada G.L., Doallo R. \& Posada D. (2012). jModelTest 2: more models, new heuristics and parallel computing. Nature Methods 9: 772. https://doi.org/10.1038/nmeth.2109

Dauby P., Scailteur Y., Chapelle G. \& De Broyer C. (2001a). Potential impact of the main benthic amphipods on the eastern Weddell Sea shelf ecosystem (Antarctica). Polar Biology 24 (9): 657-662. https://doi.org/10.1007/s003000100265

Dauby P., Scailteur Y. \& De Broyer C. (2001b). Trophic diversity within the eastern Weddell Sea amphipod community. Hydrobiologia 443 (1-3): 69-86. https://doi.org/10.1023/A:1017596120422

DE BROYeR C. (1983). Recherches sur la systématique et l'évolution des crustacés amphipodes gammarides antarctiques et subantarctiques. Thèse de Doctorat en Sciences, Université Catholique de Louvain.

De Broyer C., Scailteur Y., Chapelle G. \& Rauschert M. (2001). Diversity of epibenthic habitats of gammaridean amphipods in the eastern Weddell Sea. Polar Biology 24 (10): 744-753. https://doi.org/10.1007/s003000100276

De Broyer C., Nyssen F. \& Dauby P. (2004). The crustacean scavenger guild in Antarctic shelf, bathyal and abyssal communities. Deep-Sea Research II: Topical Studies in Oceanography 51: 17331752. https://doi.org/10.1016/j.dsr2.2004.06.032

De Broyer C., Lowry J.K., JAżDŻEWSKi K. \& RoberT H. (2007). Catalogue of the Gammaridean and Corophiidean Amphipoda (Crustacea) of the Southern Ocean with distribution and ecological data. In: DE BROYER C. (ed.), Census of Antarctic Marine Life: Synopsis of the Amphipoda of the Southern Ocean. Bulletin de l'Institut Royal des Sciences Naturelles de Belgique, Biologie/Bulletin van het Koninklijk Belgisch Instituut voor Natuurwetenschappen, Biologie 77 (Supplement 1): 1-325.

D'UdEKEM D'ACOZ C. (2009). New records of Liljeborgia from Antarctic and sub-antarctic seas, with the description of two new species (Crustacea: Amphipoda: Liljeborgiidae). Bulletin de l'Institut Royal des Sciences Naturelles de Belgique, Biologie/Bulletin van het Koninklijk Belgisch Instituut voor Natuurwetenschappen, Biologie 79: 243-304.

D'UdEKEM D'ACOZ C. (2010). Contribution to the knowledge of European Liljeborgiidae (Crustacea, Amphipoda), with considerations on the family and its affinities. Bulletin de l'Institut Royal des Sciences Naturelles de Belgique, Biologie/Bulletin van het Koninklijk Instituut voor Natuurwetenschappen, Biologie 80: 127-259.

D'Udekem D'Acoz C. \& Havermans C. (2012). Two new Pseudorchomene species from the Southern Ocean, with phylogenetic remarks on the genus and related species (Crustacea: Amphipoda: Lysianassoidea: Lysianassidae: Tryphosinae). Zootaxa 3310: 1-50.

D'UdEKEM D'ACOZ C. \& HAVERMANS C. (2015). Contribution to the systematics of the genus Eurythenes S.I. Smith in Scudder, 1882 (Crustacea: Amphipoda: Lysianassoidea: Eurytheneidae). Zootaxa 3971 (1): 1-80. https://doi.org/10.11646/zootaxa.3971.1.1

D'UdEKEM D'ACOZ C. \& RoBerT H. (2008). Systematic and ecological diversity of amphipods. In: GUTT J. (ed.), The Expedition ANTARKTIS-XXIII/8 of the Research Vessel "Polarstern" in 2006/2007. Berichte zur Polar- und Meeresforschung 569: 48-56.

D'UdeKem D'ACOZ C. \& Verheye M. (2013). Taxocoenoses of amphipod crustaceans. In: GUTT J. (ed.), The Expedition of the Research Vessel "Polarstern" to the Antarctic in 2013 (ANT-XXIX/3). Berichte zur Polar- und Meeresforschung 665: 57-67.

D'UdeKem D'Acoz C. \& Verheye M.L. (2017). Epimeria of the Southern Ocean with notes on their relatives (Crustacea, Amphipoda, Eusiroidea). European Journal of Taxonomy 359: 1-553. https://doi.org/10.5852/ejt.2017.359 
Evenhuis N.L. (2003). Publication and dating of the journals forming the Annals and Magazine of Natural History and the Journal of Natural History. Zootaxa 385: 1-68.

Fernandez-Leborans G., Fernandez-Gonzalez V., SAncheZ-Jerez P. \& Roura A. (2016). Epibiontic associations between apostomid ciliates Conidophrys spp. and amphipods associated with fish farms fouling in the western Mediterranean Sea. Helgoland Marine Research 70: 12. https://doi.org/10.1186/s10152-016-0463-x

Folmer O., Black M., HoeH W., Lutz R. \& VRIJENHOEK R. (1994). DNA primers for amplification of mitochondrial cytochrome c oxidase subunit I from diverse metazoan invertebrates. Molecular Marine Biology and Biotechnology 3 (5): 294-299.

FÜtTerer D.K., BrandT A. \& Poore G.C.B. (2003). The Expeditions ANTARKTIS-XIX/3-4 of the Research Vessel POLARSTERN in 2002 (ANDEEP I and II: Antarctic benthic deep-sea biodiversity - colonization history and recent community patterns). Berichte zur Polar- und Meeresforschung 470: $1-174$.

Gomes V., Ngan P.V., De Broyer C. \& De A. C. Rocha Passos M.J. (1993). Chromosomes of the Antarctic amphipod Waldekia obesa Chevreux. Hydrobiologia 262 (2): 109-113.

https://doi.org/10.1007/BF00007511

Gomes V., NGan P.V. \& DE A. C. Rocha Passos M.J. (1995). Estudo do metabolismo de rotina e excreção de amônia do anfípoda antarctíco Waldeckia obesa em duas temperaturas distintas. Boletim do Instituto Oceanográfico, São Paulo 43 (2): 129-139.

Gosse J.-P. (1961). Poissons antarctiques récoltés par l'expédition belge IRIS 1961. Bulletin de l'Institut royal des Sciences naturelles de Belgique / Mededelingen van het Koninklijk Belgisch Instituut voor Natuurwetenschappen 37 (29): 1-10.

Graeve M., Dauby P. \& Scailteur Y. (2001). Combined lipid, fatty acid and difestive tract content analyses: a penetrating approach to estimate feeding modes of Antarctic amphipods. Polar Biology 24 (11): 853-862. https://doi.org/10.1007/s003000100295

GuINDON S. \& GASCUEL O. (2003). PhyML - a simple, fast, and accurate algorithm to estimate large phylogenies by maximum likelihood. Systematic Biology 52: 696-704.

GUTT J. (2008). The Expedition ANTARKTIS-XXIII/8 of the Research Vessel "Polarstern” in 2006/2007. Berichte zur Polar- und Meeresforschung 569: 1-152.

GuTT J. (2013). The Expedition of the Research Vessel „Polarstern“ to the Antarctic in 2013 (ANTXXIX/3). Berichte zur Polar- und Meeresforschung 665: 1-150.

HALL T. (1999). BioEdit: a user-friendly biological sequence alignment editor and analysis program for Windows 95/98/NT. Nucleic Acids Symposium Series 41: 95-98.

HAVERMANS C. (2014). Phylogeographic patterns of the Lysianassoidea (Crustacea: Peracarida: Amphipoda). In: De Broyer C., KoubBi P., Griffiths H., Raymond B., D’UdeKem D’Acoz C., VAN de Putte A.P., Danis B., Grant S., Gutt J., Held C., Hosie G., Huettmann F., Post A., RopertCoudert Y., Stoddart M., Swadling K.M. \& WAdley V. (eds), Biogeographic Atlas of the Southern Ocean: 441-447. Scientific Committee on Antarctic Research, Cambridge.

ICZN [International Commission on Zoological Nomenclature] (1999). International Code of Zoological Nomenclature. Fourth Edition adopted by the International Union of Biological Sciences. The International Trust for Zoological Nomenclature, the Natural History Museum, London.

JANECKI T. \& RAKUSA-SUSZCZEWSKI S. (2005). The influence of starvation and amino acids on metabolism of the Antarctic amphipod Waldeckia obesa. Journal of Crustacean Biology 25 (2): 196202. https://doi.org/10.1651/C-2522 
JAŻDŻEWSKA A. (2009). Antarctic necrophagous lysianassoids from a stranded fur seal carcass. Polish Polar Research 30 (1): 29-36.

JAŻDŻEWSKA A. (2011). Soft bottom sublittoral amphipod fauna of Admiralty Bay, King George Island, Antarctic. Oceanological and Hydrobiological Studies 40 (1): 1-10.

https://doi.org/10.2478/s13545-011-0001-z

JAŻDŻEWSKI K. \& KONOPACKA A. (1999). Necrophagous lysianassoid Amphipoda in the diet of Antarctic tern at King George Island, Antarctica. Antarctic Science 11 (3): 316-321.

https://doi.org/10.1017/S0954102099000401

JAŻDŻEWSKA A.M. \& SiCIŃSKI J. (2017). Assemblages and habitat preferences of soft bottom Antarctic Amphipoda: Admiralty Bay case study. Polar Biology 40 (9): 1845-1869.

https://doi.org/10.1007/s00300-017-2107-2

KAÏM-MALKA R.A. (2010). The spatheform organ: a ballasting organ in crustacean peracarid species (amphipods and isopods). Memorie del Museo Civico di Storia Naturale di Verona, serie 2, Sezione Scienze della Vita 20: 3-68.

KANDUti D., STERBENK P. \& ARTNIK B. (2016). Fluoride: a review of use and effects on health. Materia Socio-Medica 28 (2): 133-137. https://doi.org/10.5455/msm.2016.28.133-137

KanZaki N., Giblin-Davis R.M., SchefFrahn R.H., TAKi H., Esquivel A., Davies K.A., HerRe E.A. (2012). Reverse taxonomy for elucidating diversity of insect-associated nematodes: a case study with termites. PLoS ONE 7 (8): e43865. https://doi.org/10.1371/journal.pone.0043865

KeIL S., De BROYER C. \& ZAUKE G.-P. (2008). Significance and interspecific variability of accumulated trace metal concentrations in Antarctic benthic crustaceans. International Revue of Hydrobiology 93 (1): 106-126. https://doi.org/10.1002/iroh.200711006

KlAGES M. (1991). Biologische und populationsdynamische Untersuchungen an ausgewählten Gammariden (Crustacea: Amphipoda) des südöstlichen Weddellmeeres, Antarktis. PhD thesis, University of Bremen, Bremen.

Larkin M.A., Blackshields G., Brown N.P., Chenna R., McGettigan P.A., McWilliam H., Valentin F., Wallace I.M., Wilm A., Lopez R., Thompson J.D., Gibson T.J. \& Higgins D.G. (2007). Clustal W and Clustal X version 2.0. Bioinformatics 23: 2947-2948.

https://doi.org/10.1093/bioinformatics/btm404

LeE R.F., NevenZel J.C. \& PAfFenhöFER G.-A. (1970). Wax esters in marine copepods. Science 167 (3924): 1510-1511. https://doi.org/10.1126/science.167.3924.1510

Linkowski T.B., Presler P. \& ŻUKOWSKi C. (1983). Food habits of nototheniid fishes (Nototheniidae) in Admiralty Bay (King George Island, South Shetland Islands). Polish Polar Research 4: 79-95.

LOWRY J.K. \& KILGALLEN N.M. (2014). A revision of the lysianassid genus Waldeckia with the description of four new species (Crustacea, Amphipoda, Lysianassidae, Waldeckiinae subfam. nov.). Zootaxa 3784 (4): 301-345. https://doi.org/10.11646/zootaxa.3784.4.1

LOWRY J.K. \& Kilgallen N.M. (2015). A new species of Waldeckia from the Austral Isles, Society Islands (Amphipoda, Lysianassoidea, Lysianassidae, Waldeckiinae). Zootaxa 3995 (1): 78-83. https://doi.org/10.11646/zootaxa.3995.1.10

LOWRY J.K. \& Stoddart H.E. (1993). Crustacea Amphipoda: Lysianassoids from Philippine and Indonesian waters. In: Crosnier A. (ed.), Résultats des Campagnes MUSORSTOM. Volume 10. Mémoires du Muséum national d'Histoire naturelle 156: 55-109.

MATSUOKA K., KOGLund A. \& VON DeschWANDEN A. (2013). Quantarctica: A free GIS package for research, education, and operation in Antarctica. Norwegian Polar Institute seminar, Tromsø, Norway. Available from http://quantarctica.npolar.no/ [accessed 5 March 2018]. 
NAGATA K. (1986). Amphipod crustaceans found near Syowa Station, Antarctica, Pt. 1. Memoirs of the National Institute of Polar Research, Special Issue 40: 249-258.

Nyssen F., Brey T., Lepoint G., Bouquegneau J.-M., De Broyer C. \& Dauby P. (2001). Use of stable isotopes to delineate amphipod trophic status in Antarctic food webs. Polskie Archiwum Hydrobiologii 47 (3-4): 579-584.

Nyssen F., Brey T., Lepoint G., Bouquegneau J.-M., De Broyer C. \& Dauby P. (2002). A stable isotope approach to the eastern Weddell Sea trophic web: focus on benthic amphipods. Polar Biology 25 (4): $280-287$.

NySSEN F., BREY T., DAUBY P. \& GRAEVE M. (2005). Trophic position of Antarctic amphipodsenhanced analysis by a 2-dimensional biomarker assay. Marine Ecology Progress Series 300: 135-145. https://doi.org/10.3354/meps300135

OfFredo C. \& Ridoux V. (1986). The diet of Emperor Penguins, Apetnodytes forsteri in Adélie Land, Antarctica. Ibis 128 (3): 409-413. https://doi.org/10.1111/j.1474-919X.1986.tb02690.x

Peck L.S., Clark M.S., Morley S.A., Massey A. \& Rossetti H. (2009). Animal temperature limits and ecological relevance: effects of size, activity and rates of change. Functional Ecology 23 (2): 248256. https://doi.org/10.1111/j.1365-2435.2008.01537.x

Pfeffer G. (1888). Die Krebse von Süd-Georgien nach der Ausbeute der Deutschen Station 1882-83. 2.Teil. Die Amphipoden. Jahrbuch der hamburgischen wissenschaftlichen Anstalten 5: 75-142, pls 1-3.

PRESLER P. (1986). Necrophagous invertebrates of the Admiralty Bay of King George Island (South Shetland Islands, Antarctica). Polish Polar Research 7: 25-61.

Puillandre N., Lambert A., Brouillet S. \& Achaz G. (2012). ABGD, Automatic Barcode Gap Discovery for primary species delimitation. Molecular Ecology 21 (8): 1864-1877.

https://doi.org/10.1111/j.1365-294X.2011.05239.x

RAKUSA-SUSZCZEWSKI R.S. (1982). The biology and metabolism of Orchomene plebs (Hurley, 1965) (Amphipoda: Gammaridea) from McMurdo Sound, Ross Sea, Antarctic. Polar Biology 1(1): 47-54. https://doi.org/10.1007/BF00568754

RAKUSA-SUSZCZEWSKI S. \& LACH A. (1991). Respiration of Orchomene plebs (Hurley, 1965) and Waldeckia obesa (Chevreux, 1905) from Admiralty Bay (South Shetlands Islands, Antarctic). Hydrobiologia 223 (1): 177-180. https://doi.org/10.1007/BF00047639

RAKUSA-SUSZCZEWSKI R.S., JANECKI T. \& DOMANOV M.M. (2010). Starvation and Chemoreception in Antarctic Benthic Invertebrates. Biology Bulletin 37 (1): 56-62.

https://doi.org/10.1134/S1062359010010085

RAuschert M. \& ARnTZ W.E. (2015). Antarctic Macrobenthos. A Field Guide of the Invertebrates living at the Antarctic Seafloor. Arntz \& Rauschert Selbstverlag, Deichweg.

REN X. \& HUANG L. (1991). Studies on Gammaridea and Caprellidea (Crustacea: Amphipoda) from the northwest waters of the Antarctic Peninsula. Studia Marina Sinica 32: 187-323.

Ronquist F., Teslenko M., van der Mark P., Ayres D., Darling A., Höhna S., Larget B., Liu L., SUCHARD M.A. \& HuELSENBECK J.P. (2012). MrBayes 3.2: Efficient Bayesian phylogenetic inference and model choice across a large model space. Systematic Biology 61: 539-542.

https://doi.org/10.1093/sysbio/sys029

SANDS M., NiCOL S. \& MCMinN A. (1998). Fluoride in Antarctic marine crustaceans. Marine Biology 132: 591-598. https://doi.org/10.1007/s002270050424

SchellenBerg A. (1926). Die Gammariden der Deutschen Südpolar-Expedition 1901-1903. In: von Drygalski E. (ed.) Deutsche Südpolar-Expedition, 1901-1903, im Auftrage des Reichsamtes des Innern 18 (Zool. 10): 235-414. https://doi.org/10.5962/bhl.title.2166 
Schories D. \& Kohlberg G. (2016). Marine Wildlife King George Island Antarctica. Dirk Schories Publications, Rostock.

Seefeldt M.A., Weigand A.M., Havermans C., Moreira E. \& Held C. (2017). Fishing for scavengers: an integrated study to amphipod (Crustacea: Lysianassoidea) diversity of Potter Cove (South Shetland Islands, Antarctica). Marine Biodiversity: 1-24. https://doi.org/10.1007/s12526-017-0737-9

ShOEMAKER C.R. (1914). Amphipods of the South Georgia Expedition. Science Bulletin, Museum of the Brooklyn Institute of Arts and Sciences 2 (4): 73-77.

SIERAKOWSKI K. (1991). Birds and mammals in the region of SSSI No. 8 in the season 1988/89 (South Shetlands, King George Island, Admiralty Bay). Polish Polar Research 12 (1): 25-54.

StORCH V., Bluhm B., BRANDT A. \& LOMBARTE A. (1999). Anatomy, histochemistry, and ultrastucture of selected taxa. In: ARNTZ W. \& GUTT J. (eds), The Expedition ANTARKTIS XV/3 (EASIZ II) of RV "Polarstern" in 1998. Berichte zur Polarforschung 301: 178-181.

Takeuchi I., Watanabe K., TAnimura A. \& Fukuchi M. (2002). Assemblages of necrophagous animals off Enderby Land, East Antarctica. Polar Biology 24 (9): 650-656.

https://doi.org/10.1007/s003000100264

Tamura K., Stecher G., Peterson D., Filipski A. \& Kumar S. (2013). MeGA6: molecular evolutionary genetics analysis version 6.0. Molecular Biology and Evolution 30 (12): 2725-2729. https://doi.org/10.1093/molbev/mst197

Thurston M.H. (1974). Crustacea Amphipoda from Graham Land and the Scotia Arc, collected by Operation Tabarin and the Falkland Islands Dependencies Survey, 1944-59. British Antarctic Survey Scientific Reports 85: 1-89.

VAYSSIÈRE A. (1906a). Sur les gastéropodes nudibranches et sur les Marséniadés de l'expédition antarctique du Dr Charcot. Comptes rendus hebdomandaires des séances de l'Académie des sciences 142: 718-719.

VAYSSIÈRE A. (1906b). Diagnoses génériques de Mollusques Gastéropodes nouveaux rapportés par l'Expédition antarctique du Dr Charcot. Bulletin du Muséum d'Histoire Naturelle, Paris 12 (3): 147149.

VAYSSIÈRE A. (1906c). Mollusques nudibranches et marséniadés. Expédition Antarctique Française (1903-1905) commandée par le Dr Jean Charcot. Sciences Naturelles: Documents Scientifiques: 1-51, pls 1-4. Masson et Cie (eds), Paris. https://doi.org/10.5962/bhl.title.7063

VERHEYE M. (2010). Systématique et diversité génétique des Eusirus de l'Océan Austral (Crustacea, Amphipoda, Eusiridae). Msc thesis, Université catholique de Louvain, Louvain-la-Neuve.

Verheye M., BACKELJAU T. \& D'UdEKEM D’ACOZ C. (2016). Looking beneath the tip of the iceberg: diversification of the genus Epimeria on the Antarctic shelf (Crustacea, Amphipoda). Polar Biology 39 (5): 925-945. https://doi.org/10.1007/s00300-016-1910-5

WALKer A.O. (1906). Preliminary descriptions of new species of Amphipoda from the 'Discovery' Antarctic Expedition, 1902-1904. Annals and Magazine of Natural History, series 717 (101): 452-458.

WALKer A.O. (1907). Crustacea. III. Amphipoda. National Antarctic Expedition 1901-1904. Natural History 3: 1-39, pls 1-13.

ZhANG J., KAPLI P., PAVLIDIS P. \& STAMATAKIS A. (2013a). A general species delimitation method with applications to phylogenetic placements. Bioinformatics 29: 2869-2876.

https://doi.org/10.1093/bioinformatics/btt499

ZhANG L., LU X., WANG Z., QIN L., YUAN L., YIN X. (2013b). Evaluation of the toxicity of fluorine in Antarctic krill on the soft tissues of Wistar rats. Advances in Polar Science 24 (2): 128-132. https://doi.org/10.3724/SP.J.1085.2013.00128 
ZDZITOWIECKI K. (2001). Acanthocephala occurring in intermediate hosts, amphipods, in Admiralty Bay (South Shetland Islands, Antarctica). Acta Parasitologica 46 (3): 202-207.

ZDZITOWIECKI K. \& PRESLER P. (2001). Occurrence of Acanthocephala in intermediate hosts, Amphipoda, in Admiralty Bay, South Shetland Islands, Antarctica. Polish Polar Research 22 (3-4): 205-212.

Manuscript received: 3 July 2017

Manuscript accepted: 6 February 2018

Published on: 19 April 2018

Branch editor: Tom Artois 